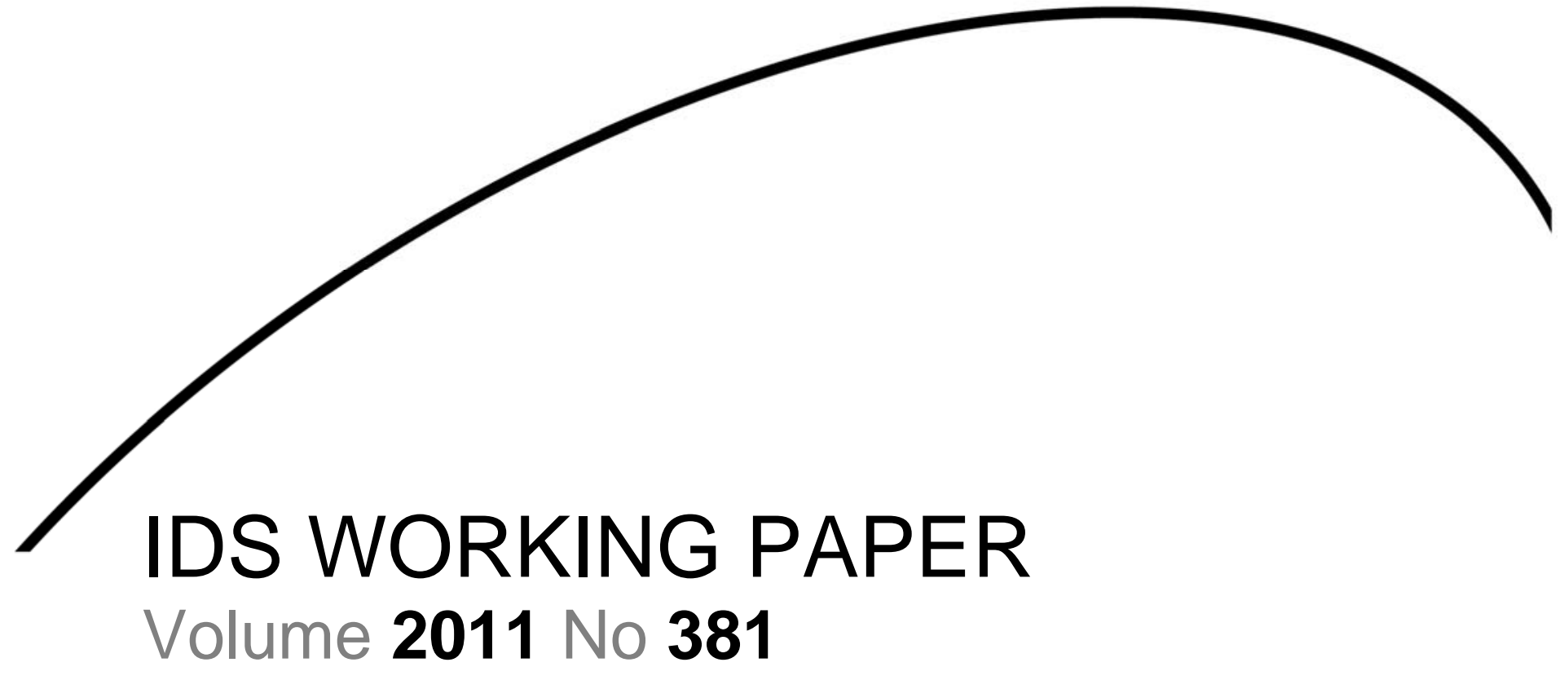

\title{
Education and Conflict Recovery: The Case of Timor Leste
}

Patricia Justino, Marinella Leone

and Paola Salardi

November 2011

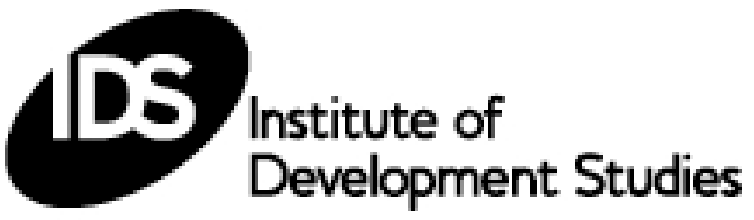


The Conflict, Violence and Development Research Cluster is part of the Vulnerability and Poverty Reduction Team at the Institute of Development Studies. The Cluster's main focus is to develop new insights into how people in contexts of conflict and violence live and interact, and what institutions help (or hinder) them. We aim to use our research findings to inform, identify and develop policies and practices that will strengthen people's own efforts to survive and make a living.

Email: conflict@ids.ac.uk

Web: www.ids.ac.uk/go/research-teams/vulnerability-and-poverty-reduction-team/researchthemes/conflict

\section{CVD WP3}

Education and Conflict Recovery: The Case of Timor Leste

Patricia Justino, Marinella Leone and Paola Salardi

IDS Working Paper 381

First published by the Institute of Development Studies in November 2011

(C) Institute of Development Studies 2011

ISSN: 1353-6141 ISBN: 978-1-78118-032-7

A catalogue record for this publication is available from the British Library.

All rights reserved. Reproduction, copy, transmission, or translation of any part of this publication

may be made only under the following conditions:

- with the prior permission of the publisher; or

- with a licence from the Copyright Licensing Agency Ltd., 90 Tottenham Court Road, London

W1P 9HE, UK,

or from another national licensing agency; or

- under the terms set out below.

This publication is copyright, but may be reproduced by any method without fee for teaching or nonprofit purposes, but not for resale. Formal permission is required for all such uses, but normally will be granted immediately. For copying in any other circumstances, or for reuse in other publications, or for translation or adaptation, prior written permission must be obtained from the publisher and a fee may be payable.

Available from:

Communications Unit, Institute of Development Studies, Brighton BN1 9RE, UK

Tel: +44 (0) $1273915637 \quad$ Fax: +44 (0) 1273621202

E-mail: bookshop@ids.ac.uk

Web: www.ids.ac.uk/ids/bookshop

IDS is a charitable company limited by guarantee and registered in England (No. 877338) 


\title{
Education and Conflict Recovery: The Case of Timor Leste
}

\author{
Patricia Justino, Marinella Leone and Paola Salardi
}

\begin{abstract}
Summary
The Timor Leste secession conflict lasted for 25 years. Its last wave of violence in 1999, following the withdrawal of Indonesian troops, generated massive displacement and destruction with widespread consequences for the economic and social development of the country. This paper analyses the impact of the conflict on the level and access to education of boys and girls in Timor Leste. We examine the short-term impact of the 1999 violence on school attendance and grade deficit rates in 2001, and the longer-term impact of the conflict on primary school completion of cohorts of children observed in 2007. We compare also the educational impact of the 1999 wave of violence with the impact of other periods of highintensity violence during the 25 years of Indonesian occupation. The short-term effects of the conflict are mixed. In the longer term, we find a strong negative impact of the conflict on primary school completion among boys of school age exposed to peaks of violence during the 25-year long conflict. The effect is stronger for boys attending the last three grades of primary school. This result shows a substantial loss of human capital among young males in Timor Leste since the early 1970s, resulting from household investment trade-offs between education and economic survival.
\end{abstract}

Keywords: conflict; education; children; gender.

Patricia Justino is a Research Fellow at the Institute of Development Studies, specialising in applied microeconomics. Her current research work focuses on the impact of violence and conflict on household welfare, the microfoundations of violent conflict and the implications of violence for economic development. She is the Director of MICROCON and co-founder and co-director of the Households in Conflict Network. Since June 2010, Patricia convenes the IDS Vulnerability and Poverty Reduction team cluster on Conflict, Violence and Development.

Marinella Leone is a DPhil student in the Department of Economics at the University of Sussex. Her main research interests are development economics and applied microeconometrics, in particular child labour, education and the economic impact of conflicts.

Paola Salardi is a DPhil student in the Department of Economics at the University of Sussex. Her primary research interests are in labour economics and applied microeconometrics, while she is also currently working in the field of the economics of conflict. 


\section{Contents}

Summary, keywords, author notes 3

Acknowledgements $\quad 5$

Introduction $\quad 6$

$\begin{array}{lll}1 & \text { Literature review } & 8\end{array}$

2 Violent conflict and the education sector in Timor Leste 9

2.1 A brief history of Timor Leste $\quad 9$

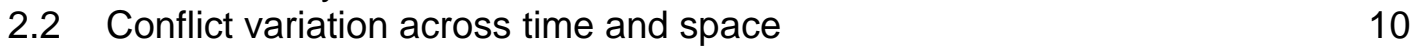

2.3 The education sector in Timor Leste 12

$3 \quad$ Identification strategy and data description $\quad 14$

3.1 Identification strategy: The impact of violence on school attendance

in $2001 \quad 15$

3.1.1 Primary school attendance and grade deficit rates in $2001 \quad 16$

$\begin{array}{ll}\text { 3.1.2 Empirical strategy } & 17\end{array}$

3.1.3 Potential biases and identification concerns 22

3.2 Identification strategy: The impact of violence on primary school
completion in 2007

3.2.1 The educational impact of the 1999 wave of violence 27

3.2.2 The educational impact of earlier peaks of violence and of the
overall conflict

3.2.3 Empirical strategy and descriptive statistics 31

3.2.4 Potential sample biases and identification concerns 33

$4 \quad$ Empirical results $\quad 34$

4.1 School attendance in $2001 \quad 34$

4.2 School completion in $2007 \quad 37$

$\begin{array}{lll}4.3 & \text { Robustness checks } & 40\end{array}$

4.3.1 Civil war exposure in 2006

4.3.2 Migration biases in the analysis of school outcomes in 2001
and 2007

5 Conclusions $\quad 44$

$\begin{array}{ll}\text { References } & 46\end{array}$

Maps

$\begin{array}{lll}\text { Map } 2.1 \quad \text { Timor Leste } & 9\end{array}$

Figures

Figure 2.1

Number of violations over time 11

Figure 2.2a Number of killings over time and across districts 11

Figure 2.2b Number of deaths due to deprivation over time and across districts 12

$\begin{array}{lll}\text { Figure 2.3 Average educational grade achieved by gender } & 14\end{array}$

Figure 3.1 School attendance rates by channel of violence exposure 19

Figure 3.2 Grade deficit by channel of conflict exposure 21

Figure 3.3a Pre-conflict trends in education levels, displacement 26

Figure 3.3b Pre-conflict trends in education levels, house completely damaged 26

$\begin{array}{lll}\text { Figure 3.4 } & \text { Average primary school completion by gender, } 2007 & 27\end{array}$

Figure 3.5 Kernel density plot of number of killings 28 
Tables

Table 3.1

Attendance rates of children aged between 7-12 years, 2001

Table 3.2 Grade deficit of children aged between 7-12 years, 2001

Table 3.3 Individual and Household characteristics by channel of violence exposure

Table 3.4 Years in which individuals were supposed to attend primary school (by year of birth)

Table 3.5 Number of years of exposure to the conflict in each district and year 30

Table 3.6 Average primary school completion in 2007, by exposed and not exposed

Table 3.7 Placebo test for differences in trends in education levels

Table 4.1 Impact of 1999 violence on school attendance in 2001 (fixed effect model)

Table 4.2 Impact of 1999 violence on grade deficit in 2001 (fixed effect model) 36

Table 4.3 Effect of 1999 violence on primary school completion in 2007, Sample 1977-1992

Table 4.4 Effect of early years of conflict on primary school completion in 2007, Sample 1968-1984

Table 4.5 Effect of early years of conflict on primary school completion in 2007, Sample 1968-1984

Table 4.6 Effect of entire conflict on primary school completion in 2007, Sample 1968-1992

Table 4.7 Robustness check. Effect of conflict on primary school completion in 2007, controlling for 2007 civil violence

Table 4.8 Robustness check. Impact of 1999 violence on school attendance in 2001, controlling for migration

Table 4.9

Robustness check. Impact of 1999 violence on grade deficit in 2001, controlling for migration

Table 4.10

Robustness check. Effect of conflict on primary school completion in 2007, controlling for migration

\section{Acknowledgements}

This paper is a product of the Gender and Development Unit, Poverty Reduction and Economic Management Network, with generous funding from the Government of Norway. It is part of a larger effort by the World Bank to provide open access to its research and make a contribution to development policy discussions around the world. The paper was first published as Policy Research Working Paper 5774. World Bank Policy Research Working Papers are also posted on the web at http://econ.worldbank.org.

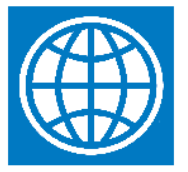

This paper was commissioned by the World Bank as a background paper to the World Development Reports 2011 and 2012. We are very grateful to the Bank for financial support for the project and very useful comments from Toan Do and Monica Das Gupta. We would also like to thank Ana María Ibáñez, Olga Shemyakina, Philip Verwimp, Barry Reilly, Sylvie Lambert, Denis Cogneau, Marc Gurgand and participants in two workshops in Washington DC and Oslo for valuable discussions and comments. All remaining errors are ours. 


\section{Introduction}

Violent conflict is one of the most important development challenges facing the world today. The incidence of wars has decreased in recent years (Harbom and Wallensteen 2009). However, the legacy of violence persists in many regions, affecting millions of men, women and children (Geneva Declaration Secretariat 2008; UNHCR 2008). The economic, political and social consequences of violence are far-reaching. Violent forms of conflict kill, injure and displace people, destroy physical capital and infrastructure and change the ways in which societies are organized. These effects will have considerable consequences for the longterm human capital accumulation of populations exposed to violence. This is well visible in the fact that no conflict-affected country will reach the Millennium Development Goals by 2015 (DFID 2009): conflict-affected countries contain one-third of those living in extreme poverty, and are responsible for almost one-half of child mortality in the world (Collier 2007; DFID 2009). They also account for 42 per cent of all out-of-school children (28 million children), even though only 18 per cent of all children in the world of primary school age live in conflict-affected countries (UNESCO 2011).

The objective of this paper is to examine one important channel linking violent conflict and development outcomes: the level and access to education of children living in contexts of conflict and violence. The paper focuses on the impact of the conflict in Timor Leste on primary school attendance, grade deficits and primary school attainments of boys and girls. We look in particular at the impact of the last wave of violence in 1999 that followed the withdrawal of Indonesian troops from the territory. We analyse the short-term impact of the 1999 wave of violence on primary school attendance and primary school grade deficits in 2001, and the medium-term impact on primary school completion in 2007. In addition, we are also able to examine separately the impact of early periods of high-intensity violence of the 25 years of Indonesian occupation. This rich amount of information allows us to compare and contrast the impact of different processes of violence that take place in long-lasting conflicts. Finally, we assess also the effects of the entire conflict on primary school completion in 2007 in order to check whether the average impact is different or in line with analyzing singularly peaks of violence. To the best of our knowledge this is the first time that researchers are able to compare the impact of violence on educational outcomes in the short, medium and long terms. The paper represents also one of the very first attempts to quantify empirically the impact of the violence in Timor Leste on individuals exposed to the 25 years of violent conflict. To this purpose, we make use of three unique datasets that allow us to understand in detail the mechanisms linking violence and educational achievement.

From a theoretical point of view, the long-term developmental effects of violent conflict are ambiguous. Standard neoclassical growth models predict high rates of growth in the postconflict period as the economy converges to its steady state growth rate. In particular, the temporary destruction of capital can be overcome in the long-run by higher investments in affected areas. ${ }^{1}$ Violent conflict may also be associated with long term positive developmental outcomes via greater popular participation in civic and political institutions (Bellows and Miguel 2006; Blattman 2009), and increases in trust and cooperation (Voors et al. 2010).

But the long-term destructive effects of violent conflict may remain entrenched in certain regions and among some population groups even if economic growth converges at the aggregate level. Recent research on the micro-level effects of violent conflict has shown that the negative impact of conflict on educational outcomes, labor market participation and

See discussion in Blattman and Miguel (2010), and evidence in Bellows and Miguel (2006), Davis and Weinstein (2002), Brakman, Garrtesen and Shramm (2004), Miguel and Roland (2006), Justino and Verwimp (2006) and Chen, Loayza and Reynal-Querol (2007). 
health status of individuals and households may be observed decades after the conflict (Akbulut-Yuksel 2009; Akresh and de Walque 2008; Alderman, Hoddinott and Kinsey 2006; Bundervoet, Verwimp and Akresh 2009; Ibáñez and Moya 2009; Shemyakina 2010). Although these effects may average out at the aggregate level, they may contribute to the emergence of poverty traps among specific groups affected by violence (Justino 2009, 2010a).

Children may be particularly affected by conflict given that many key human capital investments are age-specific. Violent conflict can interrupt the education of children through the destruction of schools, the targeting of teachers, the increase in fear and insecurity, changes in family structures and changes in household asset holdings and income (Justino 2010b; UNESCO 2011). Conflict may also impact negatively on children through health and nutritional channels, due to the association of violent conflict with famines, malnutrition, the outbreak of infectious diseases, post-war trauma, and the destruction of health facilities. In addition, household coping strategies during conflict often lead to rises in child labor and the removal of children from school (Rodriguez and Sanchez 2009). The destruction of human capital during childhood in turn is a well-documented mechanism underlying the emergence of poverty traps, given the severe long-run intergenerational effects it can have on individual and household welfare (Becker 1962; Case and Paxson 2008; Maccini and Young 2009; Mincer 1974; Shultz 1961).

These micro-level effects of violent conflict remain largely under-researched. In this paper, we focus on the analysis of the impact of 25 years of violent conflict in Timor Leste on several educational outcomes among cohorts of boys and girls of primary school age affected by the violence. We measure the short-term effects of conflict at the household level using information on household displacement and the destruction of household dwellings during the violent events. We are also able to measure conflict intensity across time including peaks of violence at various stages of the conflict - at the district level from event data on violence intensity during the conflict in Timor Leste. We focus on primary school effects because only a small percentage of the Timorese population attended secondary school.

Our results show mixed evidence for the impact of violent conflict on educational outcomes. Mirroring some of the findings of Bellows and Miguel (2006) and others, we find evidence for a rapid recovery of the education sector in Timor Leste, and of educational outcomes, particularly for girls. However, in line with emerging results in the micro-level literature, we find that the 1999 wave of violence in Timor Leste - as well as peaks of violence in the 1970s and 1980s - resulted in negative effects on primary school attendance and attainment. This effect is particularly strong for boys. We attribute the first result to a process of educational catch-up among girls in Timor Leste that started before the conflict and continued despite the conflict. The second result is likely to be due to large rates of grade repetition and of delay entry that were exacerbated by the need to remove boys from school due to the negative economic effects of the conflict on households more exposed to the violence.

The paper is structured as follows. In Section 1, we present a literature review on the impact of violent conflict on development outcomes in general and education in particular. Section 2 provides a descriptive background of the conflict in Timor Leste and the country's education sector. In Section 3, we describe the datasets, discuss our identification strategy and present some descriptive results. Section 4 discusses our empirical results, as well as a range of robustness checks. Section 5 concludes the paper. 


\section{Literature review}

An emerging body of literature has provided valuable empirical evidence on the effects of violent conflict on income and consumption levels, and more generally on the welfare of populations living in areas of violence (Ibáñez and Moya 2009; Justino and Verwimp 2006; Verwimp and Bundervoet 2008). A significant number of studies have also examined the health impact of violent conflict, finding that violence results in negative health effects in terms of lower height-for-age and lower nutritional outcomes among children that will generate long-term consequences on future outcomes. ${ }^{2}$

There is also some research on the effect of violent conflict on education. Despite the emerging nature of this empirical literature, a few common themes have started to surface (Justino 2010b). The first is that violent conflict almost always results in reductions in education access and attainment. Alderman, Hoddinott and Kinsey (2006) find that Zimbabwean children affected by the civil war in the 1970s and ensuing droughts completed fewer grades of schooling and/or started school later than those not affected by the shocks. Akresh and de Walque (2008) find a negative impact of the Rwanda genocide on the educational outcomes of children (boys in particular) that were of schooling age in 1994. Shemyakina (2010) finds that the 1992-98 civil war in Tajikistan had a negative effect on school enrolment of girls (but not of boys). Girls that lived in conflict-affected regions were 12 per cent less likely to complete mandatory schooling in comparison with girls who completed their schooling before the conflict started. They are also seven per cent less likely to complete school than girls of the same age who lived in regions relatively unaffected by the civil war. Similar negative impacts are reported in Angrist and Kugler (2008) and Rodriguez and Sanchez (2009) for Colombia, Chamarbagwala and Morán (2009) for Guatemala and de Walque (2004) and Merrouche (2006) for Cambodia.

The second major finding is that relatively minor shocks to educational access during childhood can lead to significant and long-lasting detrimental effects on individual human capital formation in terms of educational attainment, health outcomes and labor market opportunities. Akbulut-Yuksel (2009) finds strong evidence for long-lasting detrimental effects of Allied bombing in Germany during WWII on education, health and labor market outcomes of individuals who were at school-age during WWII. Sixty years after the end of the war, these individuals were observed to have fewer years of schooling on average in adulthood, were about one centimeter shorter and had lower self-reported health satisfaction in adulthood. At first glance these appear to be very small effects (between 0.4 and 1.2 years of schooling on average). However, they translated into a very significant reduction of six per cent in labor market earnings, in relation to those not affected by the bombings. Ichino and Winter-Ebner (2004) show that Austrian and German children who were ten years old during WWII lost around 20 per cent of a year of schooling on average. These negative educational effects of the war, and consequent reduction in earnings, are reflected in significant reductions in overall GDP in Germany and Austrian almost forty years after the war. Merrouche (2006) analyses the long-run effects of land mine contamination on human capital in Cambodia 30 years after the end of the Khmer Rouge regime. She finds that landmine exposure resulted in a loss of about 0.4 years of education, a significant estimate given that the average number of years of education of the sample was around 4.5 years.

Thirdly, the exposure of households to violence results in significant gender differentials in individual educational outcomes. Shemyakina (2010) finds that exposure to the Tajik conflict, as measured by physical damage to households' dwellings, had a significant and negative effect on the enrolment of girls. She observes little or no effect on the enrolment of boys, and 
postulates that households affected by conflict invested more in the schooling of boys because it may make more economic sense to educate boys. In a similar vein,

Chamarbagwala and Móran (2010) find a strong negative impact of the 1979-1984 civil war in Guatemala on female education, also attributable to the higher returns to education among boys. In contrast, Akresh and de Walque (2008) find that, in Rwanda, male children in nonpoor households experienced the most severe reductions in educational achievements following the 1994 genocide. This paper builds on and contributes to this emerging literature and findings.

\section{Violent conflict and the education sector in Timor Leste}

\subsection{A brief history of Timor Leste}

Timor Leste occupies the Eastern part of the island of Timor in the Indonesian archipelago, and includes also the island of Atauro, the island of Jaco and the enclave of Oè-Cussè. The sea surrounding Timor is rich of oil and natural gas, which largely explains the strategic interest that this small territory of just over one million people has generated in recent decades.

\section{Map 2.1 Timor Leste}

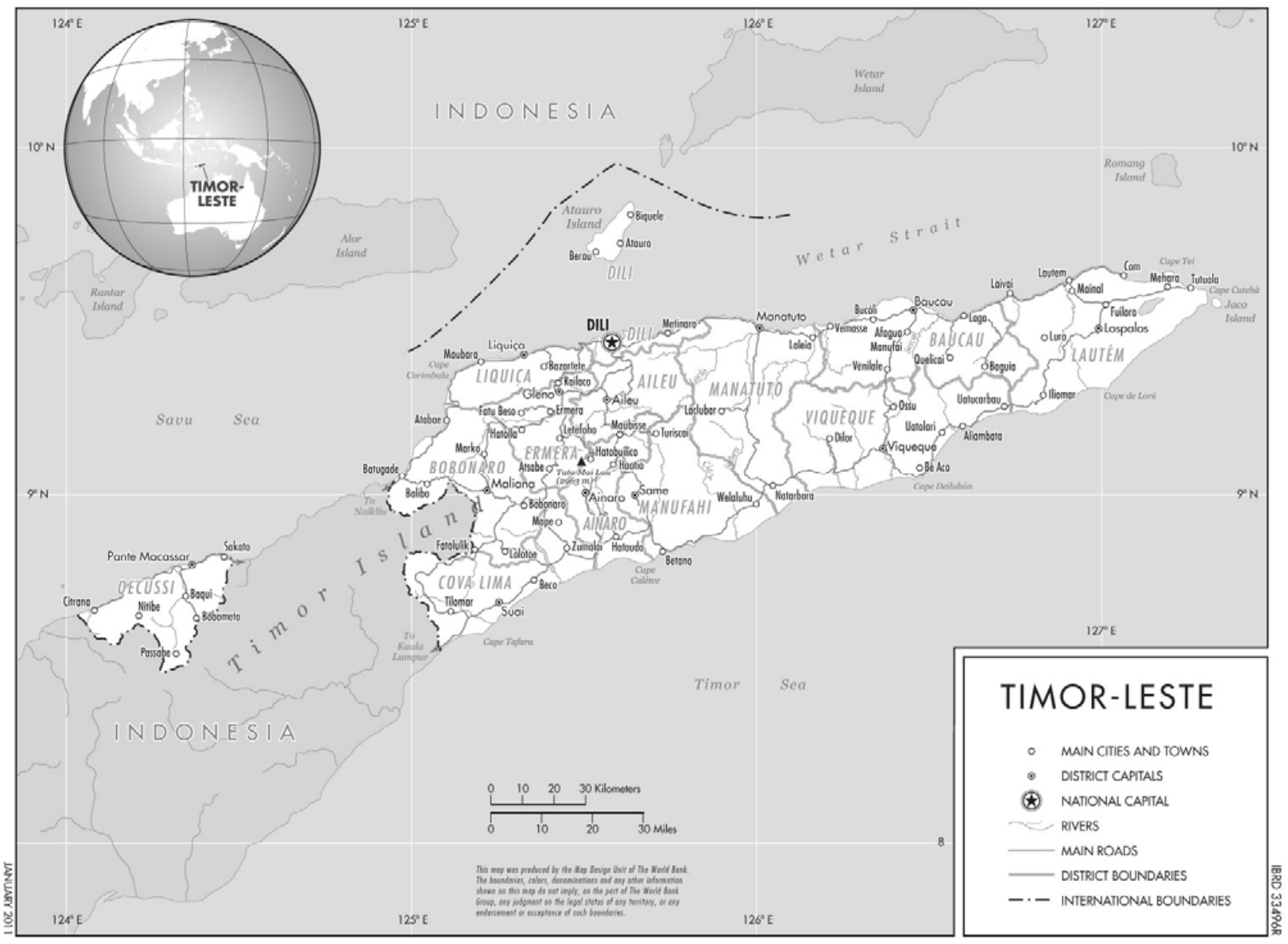


Timor Leste was under Portuguese colonial rule from 1500 until 1974. After the Portuguese left, Indonesia perceived Timor Leste as a communist threat to their national security and forcefully annexed the territory in July 1976. At that point, a guerrilla war started, spurred by the Revolutionary Front for independence (FRETILIN) and its armed wing (FALINTIL), which tried to resist the repression imposed by the Indonesian forces. In the early occupation years, a large number of civilians abandoned the towns and moved to the interior of the country, mainly to mountainous areas, to be safe from Indonesia's military control. Several thousands of individuals were forcibly displaced during the Indonesian occupation, and were made to live in extreme conditions without adequate food, shelter and health facilities. Around 60,000 people lost their lives in the early years of the occupation. The number of deaths reached 200,000 by the end of the occupation (UNDP 2002). At the same time, the Indonesian government forced many people to resettle and imposed the Indonesian language, its culture and education system. The people of Timor Leste never accepted this imposition and tried to preserve their own culture and identity. The Santa Cruz massacre in November 1991, in which 200 protesters were killed by Indonesian forces, was broadcasted by international media. This raised considerable international attention to the brutalities and human rights violations during the Indonesian occupation. Timor Leste's independence movements started then to receive support from the Portuguese government and international organizations, including the UN. These events, together with the 1997 financial crisis which badly affected the Indonesian economy and its political situation, resulted in the decision by the Indonesian government, in agreement with the Portuguese government, to hold a referendum on the independence of Timor Leste.

On 30 August 1999, 79 per cent of the Timor Leste population voted in favour of independence. The output of the referendum generated a wave of destruction, violence and human rights violations by Indonesian forces and pro-autonomy militia (Alonso and Brugha 2006). Large displacement movements (both forced and spontaneous) took place before and after the popular consultation in 1999. More than half of the population was displaced. Around 40 per cent of these were forcibly displaced to refugee camps in West Timor, and about 60 per cent escaped towards the mountains or somewhere else within Timor Leste (UNDP 2002). The majority of displaced and refugee populations returned back to Timor Leste shortly after the violence ended. The number of killings during this wave of violence has been estimated to be around 1,000 to 2,000 people (UNDP 2002). In addition to these deaths, the wave of violence in 1999 resulted also in the massive destruction of infrastructure, health facilities, schools and public and private buildings that the Indonesian forces found on their way towards West Timor. In October 1999, a United Nations Transitional Administration was settled in Timor Leste (UNTAET).

\subsection{Conflict variation across time and space}

The secession conflict in Timor Leste has evolved over time and across space in different ways. The Timor Leste Commission for Reception, Truth and Reconciliation (CAVR), established in 2001 and mandated by the UNTAET to 'undertake truth seeking' for the 19751999 conflict, has identified three distinct phases of the conflict during the entire period between December 1975 and September 1999. The first phase, from 1975 to 1984, is related to the initial Indonesian invasion and occupation of Timor-Leste. The first few years, from 1975 to 1979, were the most intense in terms of killings and destruction. The second phase, from 1985 to 1998, was characterized by the consolidation and normalization of the occupation. Although people were killed in this phase (for instance, during the Santa Cruz massacre), violence during this period was of relatively low intensity. The third phase of the conflict is identified with the 1999 withdrawal of Indonesian troops and the ensuing wave of violence. Figure 2.1 illustrates this variation in violence over time. 
Figure 2.1 Number of violations over time
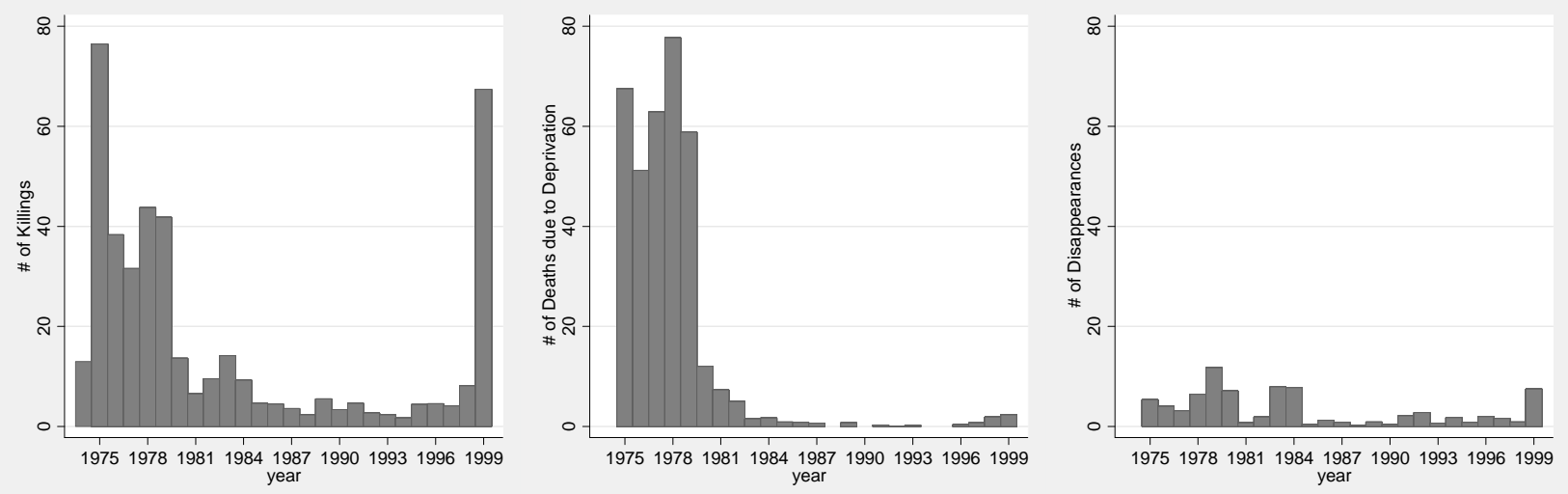

Source: Authors' own computations using CAVR (2006)

The conflict was also characterized by significant variation at the geographical level as shown in Figures 2.2a and 2.2b. Violence was mostly concentrated in specific areas and its variation at the geographical level mostly followed the movement of the Indonesian military forces. The occupation was more intense initially in the Western region of Timor Leste and it then spread to the Central and Eastern regions, with some districts in the Central region having been particularly affected. The last wave of violence in 1999 was particularly intense in the Western region and in the urban areas of the Central regions.

Figure 2.2a Number of killings over time and across districts

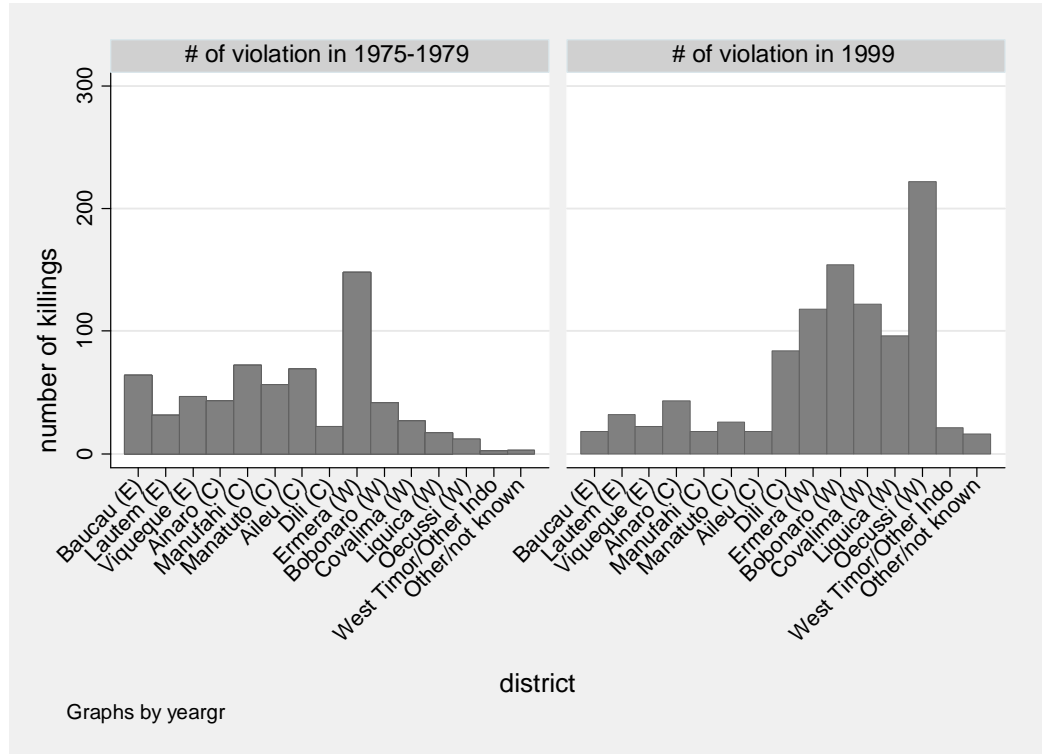

Source: Authors' own computations using CAVR (2006) 
Figure 2.2b Number of deaths due to deprivation over time and across districts

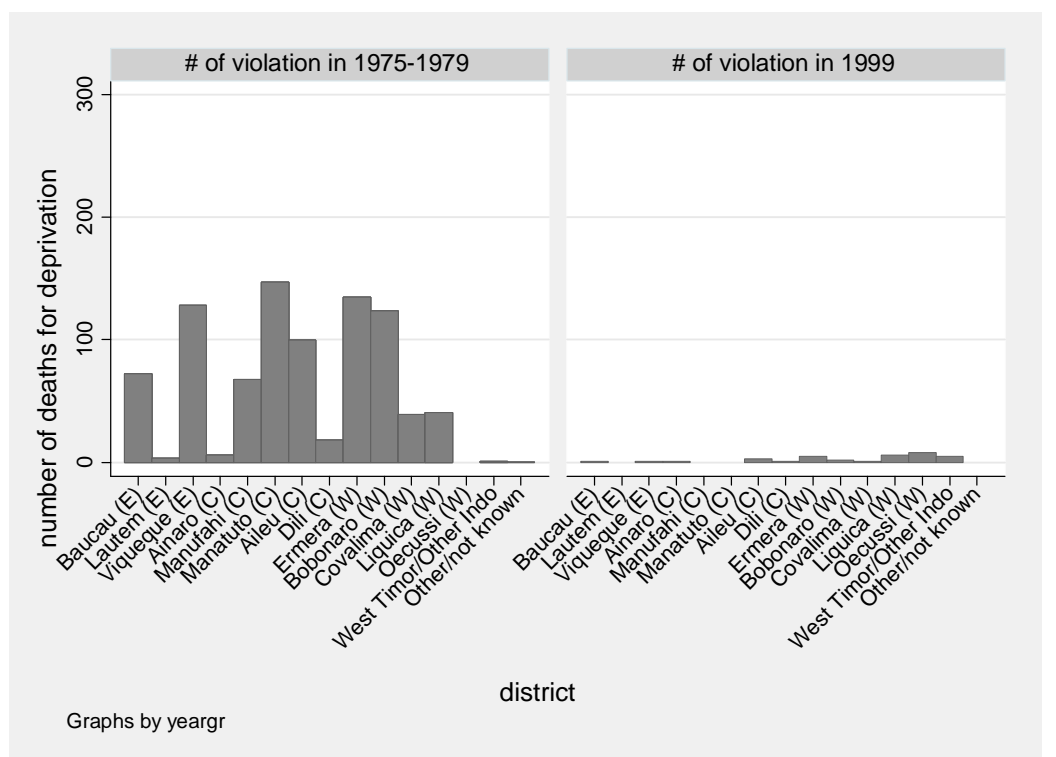

Source: Authors' own computations using CAVR (2006)

The violent attacks in 1999 were mainly conducted by militia groups with strong linkages to the Indonesian forces. These groups were first established in the Western and Central districts and then expanded to the East. The reason why the militias first emerged in the western districts and were stronger and more active in this region was mainly due to the geographical proximity to the West Timor border, which offered logistical advantages to the development of militias. The proximity to the border was also an essential condition for the massive displacement of people to West Timor. The majority of the displaced people to West Timor originated from the western districts and lived along the main roads to the border. They were attacked by the Indonesian forces and the militia while they withdrew towards West Timor after the referendum vote. The concentration of the violence in 1999 in the western districts was also due to the fact that there was a long-established network of proIndonesians that existed already before 1999. The Eastern and Central regions were, in contrast, important areas for the resistance forces (Robinson 2003). We will explore this variation of violence across time and space in more detail in the empirical sections.

\subsection{The education sector in Timor Leste}

Large amounts of funds from bilateral and multilateral donors flew into Timor Leste from 1999 onwards to support the reconstruction and rehabilitation of the country (e.g. Trust Fund for East Timor, TFET, managed by the World Bank, and other funds from bilateral donors including Portugal, Japan and the European Union). Although Timor Leste was severely devastated during the wave of violence in 1999, the rebuilt of state institutions, schools, infrastructure and markets was relatively successful and fast. The main development indicators for Timor Leste in 2001 were close to those in the pre-1999 period. But Timor Leste was (and is) still one of the world's least developed countries (UNDP 2002; WDI 2010). The evolution of education in Timor Leste has been characterized by three distinct periods, coinciding with (i) the Portuguese colonial rule (from early 1500 s to 1975), (ii) the Indonesian occupation (from 1975 to 1999) and (iii) the UNTAET administration (from October 1999 until independence in May 2002). Under Portuguese colonial rule, education was administered via the Catholic Church. Churches were the major providers of education and schooling was mostly available to the elite in urban areas. When, in 1975, Indonesia invaded the country, literacy rates were extremely low, at around five per cent (UNDP 2002). Gender disparities were also very large. 
The Indonesian government planned to expand education access to the whole population of Timor Leste. Education was used as a means to control the population, and the Portuguese and Tetum languages were abolished. Under the Indonesian education system, children had to enroll in primary school by the age of 7 , and were supposed to finish primary school at 12 years old (grade 6). In 1994, basic education was made compulsory up to low secondary school (nine grades of education up to age 15). But, as there was no enforcement mechanism to complete all nine grades, the average schooling level across the population of Timor Leste was still primary school.

Enrolment rates increased dramatically over those years, with gross enrolment ratios around 90 per cent. The gender gap also started to close down. In 1995, every village in Timor Leste had a primary school (UNDP 2002). Despite these encouraging figures, education performance under the Indonesian occupation was still characterized by delayed entry to school, high repetition rates and high drop-out rates. The net enrolment ratio in 1995 was 70 per cent. In that year, less than half of individuals aged between 15 and 19 had completed primary school education (UNDP 2002).

The main reasons explaining this poor performance were the low quality of school standards, the low quality of teachers, shortages of textbooks and classrooms, and the inability of households to pay for school fees and other additional costs, such as books or uniforms. Another reason was the unwillingness of some Timorese people to send their children to school, as this was seen as a sign of being part of the Indonesian repressive system (UNPD 2002).

After the referendum in 1999, almost all schools were destroyed and most teachers fled to Indonesia. The school system was almost totally destroyed in the ensuing wave of violence, and schools did not reopen until October $2000 .^{3}$ The reconstruction process in the aftermath of 1999 was very rapid as significant flows of international aid reached the country.

Immediately after 1999, primary school enrolment rates increased significantly with a large number of over-age students enrolling in primary school for the first time. This created an enrolment 'bulge' in primary school levels (Nicolai 2004). The net primary school enrolment rose by 10 percentage points (from 65 to 74 per cent) between 1999 and 2001 (World Bank 2003a). Literacy rates increased from 40 to 43 per cent between 1999 and 2001. Gender differentials shrunk significantly, mainly due to the large rise in female literacy rates from 34 to 43 per cent in the same period (World Bank 2003a).

Despite the significant increase in enrolment rates, the reconstruction of the school system in Timor Leste faced many challenges. First, there was a shortage of teachers given that the majority, being Indonesian, had left the country by the end of 1999 (UNDP 2006). There was also a shortage of teachers that could teach in Portuguese. Second, not all schools were reconstructed and, as a result, school distances were much higher for some children than before the destruction. While enrolments were high, school attendance was low. Third, emergency funds were only available for a limited period of time. In 2001, 57 per cent of the Timorese population still had no or little education.

Figure 2.3 reports the average educational grade attainment by year of birth and by gender in 2007. We include individuals born between 1950 and 1992. The data shows that cohorts that were of school age during the Indonesian occupation achieved higher level of education than older cohorts (i.e. those born in the 1970s compared to those born in the 1960s or before) testifying for an increasing trend as expected. The figure shows that despite the increasing trend a large fraction of individuals have low education levels. Interestingly, all 
curves start to drop after the 1987 cohort. This decreasing trend is observed among individuals aged 20 or younger in 2007 and provides evidence of a mismatch between the grade attended and the grade that they should have achieved at their age. ${ }^{4}$ This is caused by a persistent sluggishness in grade achievement due to the high level of delayed entry to school and high rates of repetition. ${ }^{5}$

Figure 2.3 Average educational grade achieved by gender

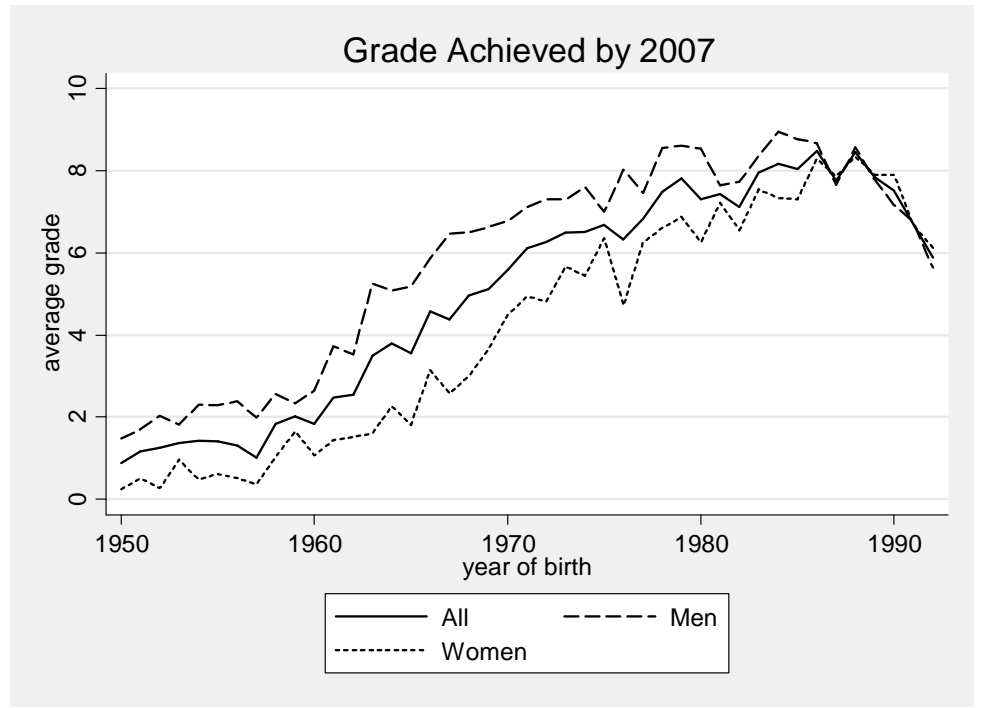

Source: Authors' own computations using TLSS (2007).

The impact of the conflict in its different phases and the subsequent reconstruction efforts on schooling levels of children in Timor Leste is therefore unclear. The early years of violence coincided with an education for all policy in which quantity was preferred to quality. In addition, the 1999 violence that followed the withdrawal of Indonesian troops led to the destruction of schools and the removal of children from school. The reconstruction program implemented after 1999 tried to counteract this destruction, and achieved fast progress. However, the education sector was still in very poor shape. In the next section, we investigate in more detail the effects of the conflict on educational outcomes of boys and girls in Timor Leste.

\section{Identification strategy and data description}

The main objective of this paper is to assess the educational effects of the conflict in Timor Leste. First, we analyse the short-term consequences of the last wave of violence in 1999 on school attendance and on grade deficit rates observed in 2001 among children who were of primary school age in 1999. Second, we examine the medium term consequences of the conflict on school attainment of the same cohort observed again in 2007. Third, we investigate the long term consequences of the most intense early years of the conflict between Timor Leste and Indonesia on school attainment outcomes of exposed individuals observed in 2007. Finally, we assess the average effect of the conflict on primary education outcomes in the longer term by looking at the average effect of exposure to the conflict as a

Those born in 1992 are 15 in 2007 . So they might have at most completed grade 9 and this justifies part of the drop in the curves as the grade completed is right censored.

The high levels of school delay are also confirmed by the figures on gross and net enrolment ratios calculated using the TLSS 2001 and 2007: primary gross enrolment ratio was 105 per cent in 2001 and 128 per cent in 2007, while net enrolment ratios were 74 and 94 per cent, respectively, in 2001 and 2007. 
whole. We focus on primary schooling because most individuals in Timor Leste (65 per cent) have at most only primary school education (TLSS 2007b). The empirical study is based on two cross-sectional household surveys: the Timor Leste Living Standard Measurement Surveys (TLSS), conducted in 2001 and 2007, jointly by the National Statistics Directorate in Timor Leste and the World Bank. They are both nationally representative household surveys, and include a broad range of individual and household level indicators.

The TLSS 2001 surveyed 1800 households from 100 Sucos (villages) (covering nearly one per cent of the population). The survey was conducted between August and November 2001. Interestingly, this survey includes very detailed information on the exposure of individuals and households to the wave of violence in 1999. Respondents were asked whether they were displaced and whether their house was destroyed due to the violent events that followed the withdrawal of Indonesian forces in 1999. We make use of this valuable information to get insights on the characteristics of individuals and households affected by the violent events in 1999.

The TLSS 2007 covered a sample of 4,477 households from all the 498 Sucos that form Timor Leste. The TLSS 2007 was undertaken over a period of 12 months between December 2007 and January 2008. The survey was in fact launched in March 2006 but had to be suspended due to the outbreak of internal violence in the country (mostly in Dili). The survey was resumed in January 2007 and conducted over one year. ${ }^{6}$ The TLSS 2007 contains the usual information included in a comprehensive household survey. But contrary to the TLSS 2001, the 2007 household survey does not contain direct information on violence exposure. In order to identify individuals and households affected by the conflict, we make use of data on events and violations contained in the Human Rights Violations Database (HRVD). This dataset is part of the CAVR Timor-Leste Data Publication, developed jointly by the Human Rights Data Analysis Group (HRDAG) and the Commission for Reception, Truth and Reconciliation (CAVR). ${ }^{7}$ This information has been collected from deponents to the Commission's statement-taking process. ${ }^{8}$ We make use of data on the number of killings that occurred during the war in order to derive patterns and variation of violence in Timor Leste over time and across space. We use this data to identify districts and years that experienced high and low violence-intensity, both at the start of the occupation and following the withdrawal of Indonesian troops in 1999. This allows us to estimate both the impact of the first years of the conflict and the impact of the last wave of violence in 1999.

\subsection{Identification strategy: the impact of violence on school attendance in 2001}

We first investigate the short-term impact of the 1999 violence. The empirical questions being addressed are: (i) whether the violence in 1999 imperiled school attendance ${ }^{9}$ and school grade deficit, and (ii) whether different channels of exposure to conflict displacement and house destruction - affected boys and girls and different age groups differently.

\footnotetext{
$6 \quad$ All households interviewed in 2006 (351 households) were revisited and re-interviewed in 2007. Those not found at the time of the new interview (34 households) were replaced with new households. For more information see http://dne.mof.gov.t//TLSLS/AboutTLSLS/index.htm.

Commission for Reception, Truth and Reconciliation \& Benetech Human Rights Data Analysis Group, 'Human Rights Violations Database', 9 February 2006, www.hrdag.org/resources/timor-leste data.shtml

$8 \quad$ There may be potential sample biases in the statement taking procedure given the voluntary nature of the process. It is possible that those living in more remote or mountainous areas, those living far away from the areas where the statements were taken, the sick, old and disabled and those with no access to the media or means of mass communication have a lower probability of being part of the sample. By contrast, those more active in local communities are more likely to have provided a testimony. In order to address these potential sample biases, the CAVR supplemented its documentation with reports produced by Amnesty International and Fokupers (a local NGO). The information contained in these reports was then included into the HRVD database.

$9 \quad$ Note that we do not analyse school completion in 2001 because most children that were of school age in 1999 were still in school in 2001.
} 


\subsubsection{Primary school attendance and grade deficit rates in $\mathbf{2 0 0 1}$}

We make use of information in TLSS 2001 collected at the individual and household levels on displacement and house destruction to identify conflict-affected individuals. We have constructed two different variables that try to account for the degree of severity of the conflict. ${ }^{10}$ The first variable identifies individuals belonging to households that were displaced due to the 1999 wave of violence (all members displaced). The second variable identifies individuals in households that report having their house completely destroyed by the violent attacks in 1999.

The TLSS 2001 contains also useful retrospective information on school attendance and grade attained across three different academic years: 1998/99, 1999/00 and 2000/01. We are interested in the year of recovery, the academic year 2000/01. Since the 1999 violence occurred mainly in the summer and fall of 1999, we can assume with a certain degree of confidence that the academic year of 1998/99 was not affected by conflict, while the academic year of 1999/00 started under the wave of violence. Almost all schools were destroyed during the violence in 1999 and most teachers escaped to West Timor during the 1999/00 academic year. Therefore, very few children were able to attend school that year. The very few that attended school were in makeshift schools in IDP camps or in the open air. We report in Table 3.1 (see over) average school attendance rates, disaggregated by gender and age groups, across these three academic years. The sample includes children aged between 7 and 12 years old over the three years considered: the sample is aged 7-10 in 1998, 8-11 in 1999 (during the violence) and 9-12 in 2000.

In general, we notice that attendance rates have increased over time and are generally higher for girls. The difference in outcomes between boys and girls is not statistically significant, but is nonetheless an interesting result. The higher attendance rates observed among girls in 1998/99 show evidence for a gender catching up phenomenon, which started before 1999. In the post-violence year, the difference in attendance rates between girls and boys becomes statistically significant, particularly for the younger cohort. This seems to suggest that educational outcomes among girls recovered faster in the post-conflict period.

In addition to the analysis of school attendance, we explore also the impact of the 1999 violence on school grade deficit. The grade deficit is computed as follows:

$$
D_{i t}=A_{j e}-6-\text { Grade attending }
$$

The TLSS 2001 does not allow us to distinguish whether the grade deficit is due to drop outs, delayed entry or grade repetition. We restrict our sample to only those children that attend all three years consecutively in order to isolate the consequences of the violence on the sample of individuals that do not drop out.

The attendance rate over the three years for all children aged 8-11 in 1999 is on average around 72 per cent (Table 3.1). The attendance rate for those that attended all three years is lower. Table 3.2 (see over) shows the average grade deficit over the three years. Two main patterns are visible. First, the average grade deficit - which was already significant in $1998 / 1999$ - increased during the conflict. Second, young girls tend to have a higher grade deficit than young boys while old girls show a lower grade deficit than older boys. The differences are however not statistically significant.

The questions we used are 'Was [NAME] displaced outside E. Timor in 1999?', and 'Was the [BUILDING] damaged in the violence of 1999?' 14 per cent of the whole sample surveyed in 2001 report having been displaced, while 26 per cent report that their house was destroyed. Within our sample of school age children, these figures are 16 per cent and 25 per cent, respectively. We have made sure that buildings that are reported to having been destroyed were used for living purposes only. 
Table 3.1 Attendance rates of children aged between 7-12 years, 2001

\begin{tabular}{|c|c|c|c|c|c|c|c|c|c|c|c|c|}
\hline & \multicolumn{4}{|c|}{ All: 8-11 years old } & \multicolumn{4}{|c|}{ Younger cohort: 8-9 years old } & \multicolumn{4}{|c|}{ Older cohort: 10-11 years old } \\
\hline & all & Boys & girls & t-test & all & boys & girls & t-test & all & boys & girls & t-test \\
\hline $1998 / 99$ & $\begin{array}{c}0.634 \\
(0.012)\end{array}$ & $\begin{array}{c}0.611 \\
(0.018)\end{array}$ & $\begin{array}{c}0.659 \\
(0.017)\end{array}$ & n.s. & $\begin{array}{c}0.509 \\
(0.020)\end{array}$ & $\begin{array}{c}0.498 \\
(0.027)\end{array}$ & $\begin{array}{c}0.521 \\
(0.028)\end{array}$ & n.s. & $\begin{array}{c}0.750 \\
(0.018)\end{array}$ & $\begin{array}{c}0.720 \\
(0.026)\end{array}$ & $\begin{array}{c}0.782 \\
(0.025)\end{array}$ & n.s. \\
\hline $1999 / 00$ & $\begin{array}{c}0.676 \\
(0.012)\end{array}$ & $\begin{array}{c}0.654 \\
(0.017)\end{array}$ & $\begin{array}{c}0.700 \\
(0.017)\end{array}$ & n.s. & $\begin{array}{c}0.622 \\
(0.019)\end{array}$ & $\begin{array}{c}0.602 \\
(0.027)\end{array}$ & $\begin{array}{c}0.647 \\
(0.028)\end{array}$ & n.s. & $\begin{array}{c}0.726 \\
(0.018)\end{array}$ & $\begin{array}{c}0.705 \\
(0.026)\end{array}$ & $\begin{array}{c}0.749 \\
(0.026)\end{array}$ & n.s. \\
\hline $2000 / 01$ & $\begin{array}{c}0.854 \\
(0.014)\end{array}$ & $\begin{array}{c}0.836 \\
(0.019)\end{array}$ & $\begin{array}{c}0.874 \\
(0.019)\end{array}$ & * & $\begin{array}{c}0.822 \\
(0.022)\end{array}$ & $\begin{array}{c}0.789 \\
(0.030)\end{array}$ & $\begin{array}{c}0.860 \\
(0.031)\end{array}$ & $\star \star$ & $\begin{array}{c}0.884 \\
(0.021)\end{array}$ & $\begin{array}{c}0.881 \\
(0.029)\end{array}$ & $\begin{array}{c}0.887 \\
(0.029)\end{array}$ & n.s. \\
\hline$N$ & 966 & 512 & 454 & & 466 & 251 & 215 & & 500 & 261 & 239 & \\
\hline
\end{tabular}

Source: Authors' computations using TLSS (2001).

Note: ${ }^{\star} p<0.10,{ }^{*} p<0.05,{ }^{* \star} p<0.01$. n.s. = not statistically significant. We consider the same cohort over time (those aged $8-11$ in 1999).

Table 3.2 Grade deficit of children aged between 7-12 years, 2001

\begin{tabular}{|c|c|c|c|c|c|c|c|c|c|c|c|c|}
\hline & \multicolumn{4}{|c|}{ All: 8-11 years old } & \multicolumn{4}{|c|}{ Younger cohort: 8-9 years old } & \multicolumn{4}{|c|}{ Older cohort: 10-11 years old } \\
\hline & All & Boys & girls & t-test & all & boys & girls & t-test & all & boys & girls & t-test \\
\hline $1998 / 99$ & $\begin{array}{c}0.628 \\
(0.089)\end{array}$ & $\begin{array}{c}0.663 \\
(0.132)\end{array}$ & $\begin{array}{c}0.591 \\
(0.119)\end{array}$ & n.s. & $\begin{array}{c}0.229 \\
(0.145)\end{array}$ & $\begin{array}{c}0.196 \\
(0.212)\end{array}$ & $\begin{array}{c}0.265 \\
(0.196)\end{array}$ & n.s. & $\begin{array}{c}0.883 \\
(0.114)\end{array}$ & $\begin{array}{c}0.976 \\
(0.170)\end{array}$ & $\begin{array}{c}0.790 \\
(0.151)\end{array}$ & * \\
\hline $1999 / 00$ & $\begin{array}{c}0.832 \\
(0.094)\end{array}$ & $\begin{array}{c}0.864 \\
(0.140)\end{array}$ & $\begin{array}{c}0.799 \\
(0.124)\end{array}$ & n.s. & $\begin{array}{c}0.444 \\
(0.154)\end{array}$ & $\begin{array}{c}0.420 \\
(0.225)\end{array}$ & $\begin{array}{c}0.471 \\
(0.207)\end{array}$ & n.s. & $\begin{array}{c}1.081 \\
(0.120)\end{array}$ & $\begin{array}{c}1.162 \\
(0.180) \\
\end{array}$ & $\begin{array}{c}1.000 \\
(0.157)\end{array}$ & n.s. \\
\hline $2000 / 01$ & $\begin{array}{c}1.007 \\
(0.098)\end{array}$ & $\begin{array}{c}1.025 \\
(0.146)\end{array}$ & $\begin{array}{c}0.989 \\
(0.130)\end{array}$ & n.s. & $\begin{array}{c}0.659 \\
(0.162)\end{array}$ & $\begin{array}{c}0.598 \\
(0.236)\end{array}$ & $\begin{array}{c}0.725 \\
(0.218)\end{array}$ & n.s. & $\begin{array}{c}1.231 \\
(0.126)\end{array}$ & $\begin{array}{c}1.311 \\
(0.188)\end{array}$ & $\begin{array}{c}1.150 \\
(0.166)\end{array}$ & n.s. \\
\hline $\mathrm{N}$ & 548 & 279 & 269 & & 214 & 112 & 102 & & 334 & 167 & 167 & \\
\hline
\end{tabular}

Source: Authors' computations using TLSS (2001).

Note: ${ }^{*} p<0.10,{ }^{* \star} p<0.05,{ }^{\star * \star} p<0.01$. n.s. $=$ not statistically significant. We consider the same cohort over time (those aged $8-11$ in 1999). The sample in this table includes only those children who attended primary school consecutively in all three years.

\subsubsection{Empirical strategy}

In order to make use of the retrospective information on school attendance provided in the dataset, we have constructed what we have called an 'ad hoc panel', whereby we exploit the time-variation of the variables of interests (age, attendance status and grade attained by the respondents) by reshaping the cross-sectional structure of the TLSS 2001 dataset. In this way, we are able to obtain observations for each individual over three academic years. All key education variables are time-variant, while other individuals and households characteristics are time-invariant.

Within these three years, we focus our analysis on individuals that were of primary school age (between 7 and 12 years old) in each year. In practice, we keep all children aged at minimum 7 years old in 1998 and at maximum 12 years old in 2000. As a consequence, our panel data contains children aged 8-11 years in 1999, the year of the violence. ${ }^{11}$ Since we are interested in looking at different effects across groups of individuals, we have split the sample between boys and girls and between younger children (aged 8-9 in 1999) and older children (aged 10-11 in 1999). We estimate the following equation:

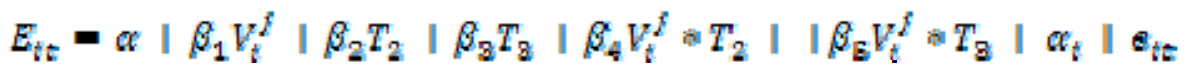

where $\Sigma_{t:}$ are our outcome variables, i.e. attendance rate (which is a binary variable) $)^{12}$ or grade deficit. $T_{2}$ and $T_{3}$ are year dummies respectively for year 2, the year of the 1999 violence, and for year 3 , the first year of the post-conflict period. The model includes

\footnotetext{
11 We have also tried to keep a larger sample that includes those children in primary school age in the year of the violence (i.e. between 7 and 12 in 1999). This means including individuals aged 6 in year 1 and aged 13 in year 3 . The inclusion of these latter individuals may generate 'spurious' results as they are not of primary school age. We have estimated the model using both samples. We find that the estimates using the larger sample are similar to those obtained with the sample of children aged between 8 and 11 in 1999. The larger sample generates more statistically significant results but we have decided to opt for the most restrictive sample to avoid inclusion of 'tails' of the age distribution that are not of primary school age.

12 We estimate our model with a linear probability model.
} 
individual fixed effects, $\alpha_{i}$. The variable $e_{i t}$ is the random error. All standard errors are clustered at the village level.

As discussed above, we identify violence-affected individuals using two different measures, $V_{t}^{Z}$, with $j=1,2$ depending on which measure is included in the specification. The first one is whether the individual was displaced with the whole household. The second is whether the individual reports that her house was completely destroyed during the 1999 violence. We allow the violence measure to interact with both year dummies. The estimation of our specification above is therefore essentially a difference-in-difference methodology (DID, hereafter). Hence, $V_{t}^{l} * T_{2}$ represents the DID term between the pre-war year and the year of conflict, while $V_{t}^{2} * T_{2}$ represents the DID term between the pre-war year and the post-war year. Given our research questions, we are more interested in the latter so we focus our attention on the coefficient $\beta_{\kappa}$.

Besides exploring the impact of each channel of violence exposure separately, we have also investigated the interaction of these two shocks by specifying a triple interaction in the equation as follows:

$$
\begin{gathered}
E_{t t}^{\prime}=\alpha+\beta_{1} V_{t}^{1}+\beta_{2} V_{t}^{2}+\beta_{8} T_{2}+\beta_{4} T_{2}+\beta_{8} V_{t}^{1} * T_{2}+\beta_{6} V_{t}^{1} * T_{8}+\beta_{7} V_{t}^{2} * T_{2}+\beta_{9} V_{t}^{2} * T_{9}+ \\
\beta_{9} V_{t}^{1} * V_{t}^{2} * T_{2}+\beta_{10} V_{t}^{1} * V_{t}^{2} * T_{8}+\alpha_{t}+\theta_{t t}
\end{gathered}
$$

This specification allows us to isolate the impact of only being displaced, only having the house destroyed and being affected by both shocks at the same time. The coefficients of interest are the interactions with $\mathrm{T}=3$, namely the year of the post-violence. In the analysis of the empirical results in the next section, we focus on the magnitude and significance of $\beta_{6}$ and $\hat{R}_{S}$ that convey the impact of only being displaced and only being affected by the house destruction and $\beta_{10}$ that convey the impact of being affected by both shocks simultaneously. We believe that this specification is more accurate and allows capturing effects otherwise ignored. $^{13}$

In order to provide some preliminary descriptive evidence of differences in attendance rates between affected and not affected individuals, we have plotted average school attendance rates and grade deficit rates between the two groups over the three years analysed. Figure 3.1 (see over, source: authors' own computations using TLSS 2001) shows attendance rates for each channel of violence exposure. Surprisingly, in the pre-conflict year, we note that attendance rates are higher for individuals in displaced households, particularly girls. This indicates that households affected by displacement are a particular type of family whose children are more likely to attend school. In the post-violence year, the attendance rates of girls that were affected by the conflict appear to have recovered faster than those of boys'. Girls affected by the conflict display also a statistically significant higher level of attendance with respect to girls not affected by the violence. But if we look at the difference between the displaced and not displaced group at $\mathrm{T}=3$ (academic year 2000/01) relative to $\mathrm{T}=1$ (academic year 1998/99), we notice that displacement has a more severe and negative impact on girls than boys (when comparing them with their respective not affected group). This larger effect on girls seems to be driven by the pre-conflict gap in school attendance levels between those affected by the violence and those not affected, which closes down considerably in the post violence year as a result of the conflict.

67.1 per cent of all children in our sample have not been affected by any shock. 7.5 per cent of all children have been displaced, and 17.4 per cent have had their house destroyed. 8 per cent of the sample was affected by both shocks during the 1999 violence. 
Figure 3.1 School attendance rates by channel of violence exposure
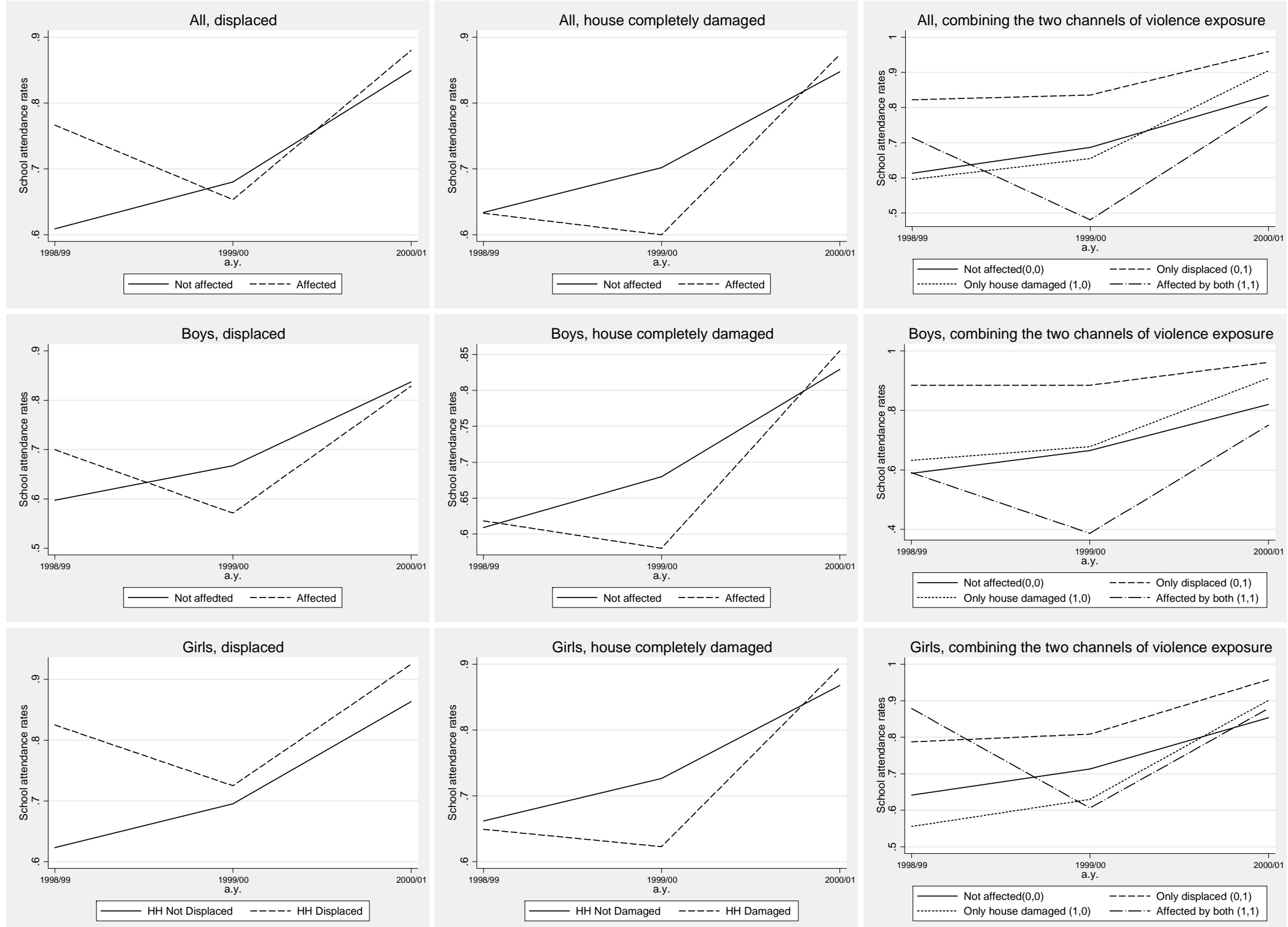
In terms of house destruction, we notice that, in the year of the violence, children affected by this type of shock have on average much lower attendance rates than those not affected by the violence. The table shows no relevant differences in patterns between boys and girls. We observe only a small positive difference when comparing the two groups between $\mathrm{T}=3$ and $\mathrm{T}=1$.

We notice in addition that those that were affected only by displacement (but not house destruction) exhibit higher attendance rates in all three periods (with the exception of girls for which the attendance rates is highest in the academic year 1998/99). If we take into account the differential effect relative to the unaffected group, we observe that the impact of displacement is negative for boys and slightly negative for girls. We find only a negligible effect of house destruction (when considered in isolation from displacement) on the education of boys. The impact of house destruction on girls' education is positive despite the fact that they start with a lower attendance rate relative to the unaffected group. Finally, school education attendance rates of children exposed to both shocks seem to have been severely affected by the conflict, and do not recover in the post-war year.

In Figure 3.2 (see over, source: authors' own computations using TLSS 2001), we report the plots for grade deficit. Children affected by displacement show lower grade deficit than those not affected. However, there does not seem to be any effect of the conflict if we compare the two groups between 2000/01 and 1998/99. Children affected by house destruction have higher grade deficit than the group not affected by house destruction. The conflict seems to have only slightly increased the gap between the two groups in comparison to the previolence year. This pattern is confirmed among children affected by both shocks simultaneously or by each of the shock separately. 
Figure 3.2 Grade deficit by channel of conflict exposure
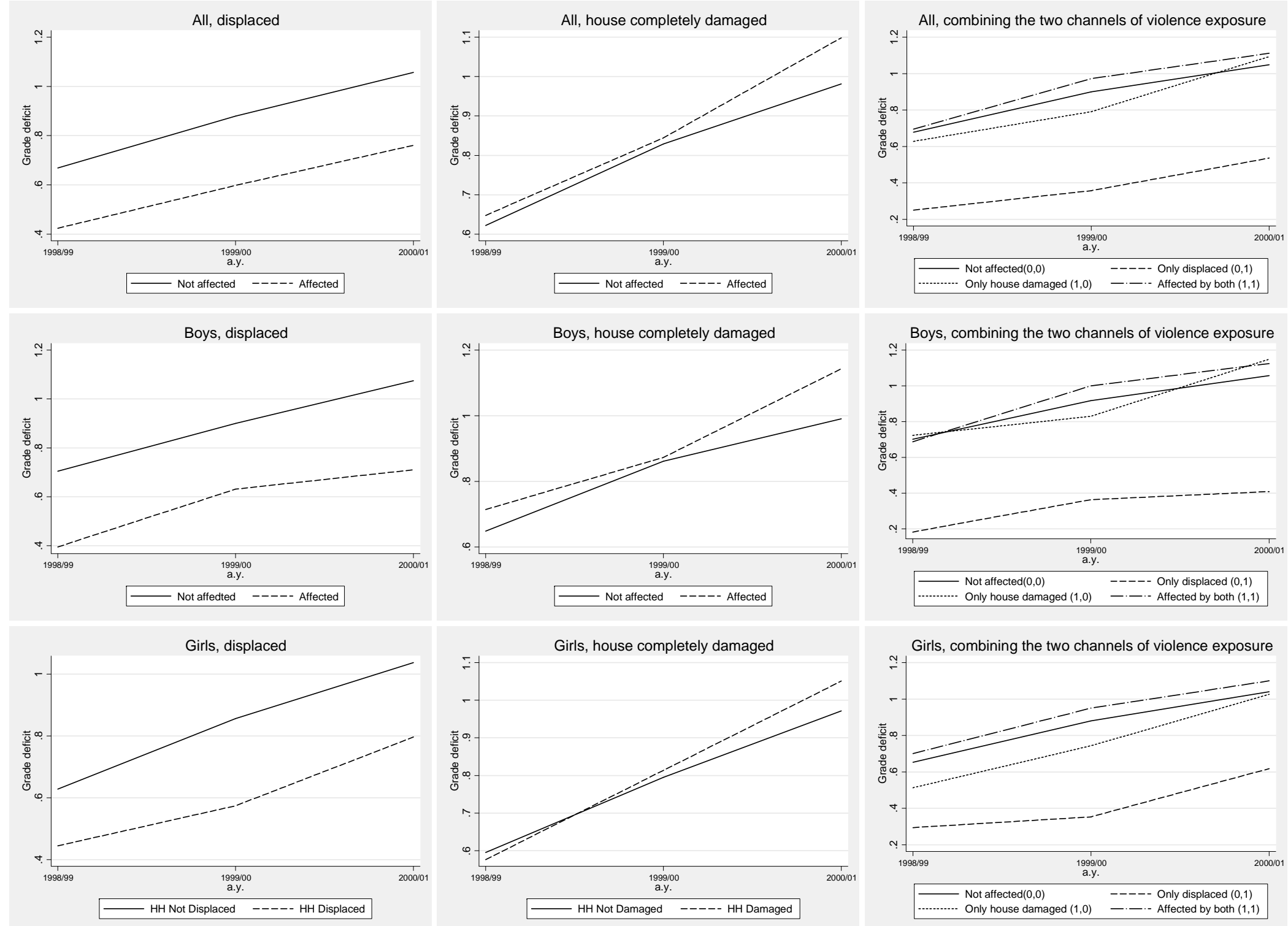


\subsubsection{Potential biases and identification concerns}

The last wave of violence of 1999 was partially indiscriminate and partially targeted at specific individuals and localities (see Section 3). We have examined some relevant individual and household characteristics of children affected by the 1999 violence, and compared with the characteristics of households that do not report having been affected by the violence in 1999. These results are presented in Table 3.3 (see over). The table reports the means for the sample of children that we analyse disaggregated by gender (Panel $A$ of Table 3.3). In panel B (page 24), we look at these characteristics by considering the interaction of the two channels of violence exposure.

The table shows interesting results. Children of displaced households are better-off economically and more educated than households that were not displaced. They are also less likely to be farmers. On the other hand, households that report having their house destroyed by violent attacks are less educated and more likely to be farmers. These key features hold when we look at the relevant characteristics by gender. Significantly, we find also that children (aged 10-12) ${ }^{14}$ affected by displacement are more likely to work than children affected by house destruction. The difference is not however statistically significant. We find statistically significant differences in labor market outcomes by gender. Notably, we notice that displaced boys are more likely to work and for longer hours than boys that were not affected by displacement. The opposite is true for girls.

The interaction between displacement and house destruction provides further insights into how the characteristics of children and their families differ relative to the type of violence they have been exposed to. Households affected by both shocks are more likely to be farmers, less educated and the poorest among the considered categories. This suggests that displaced households are likely to be urban households belonging or in some way related to the Timorese intelligentsia, who would have fled their areas of residence for fearing of being easily targeted by the Indonesian troops (see Section 2). Households that report house destruction only or both displacement and house destruction are likely to be indiscriminate victims of 'scorch-earth' tactics employed by the Indonesian troops while moving back to West Timor (Section 2).

The discussion above leads us to conclude that the likelihood of an individual having been affected by the 1999 violence was not a totally random phenomenon, and there are observable characteristics of the households related to the likelihood of having been affected by the violence. There may also be unobserved household and individual characteristics which are correlated both with the conflict and the outcome variables. ${ }^{15}$ This may potentially lead to biases in the analysis, which are typically corrected through instrumental variable estimation techniques.

Employment characteristics are collected only on individuals of 10 years or older.

One of the most common omitted variables in empirical research on the impact of violent conflict is the level of support of households for armed groups (see Wood 2003; Petersen 2001). Another common omitted variable is the level of control of different armed factions (Kalyvas 2006). In the case of Timor Leste, the level of control of FRETILIN and the Indonesian troops is likely to vary with the geographical characteristics of each area, as well as their proximity to West Timor. 


\section{Table 3.3 Individual and Household characteristics by channel of violence exposure}

\begin{tabular}{|c|c|c|c|c|c|c|c|c|c|c|c|c|c|c|c|c|c|c|c|c|c|}
\hline & \multicolumn{7}{|c|}{ All children 7-12 } & \multicolumn{7}{|c|}{ Boys 7-12 } & \multicolumn{7}{|c|}{ Girls 7-12 } \\
\hline & \multicolumn{2}{|c|}{ Displaced } & \multicolumn{3}{|c|}{ housedam } & \multirow[b]{2}{*}{ t-test } & \multirow[b]{2}{*}{ all } & \multicolumn{2}{|c|}{ displaced } & \multicolumn{3}{|c|}{ housedam } & \multirow[b]{2}{*}{ t-test } & \multirow[b]{2}{*}{ all } & \multicolumn{2}{|c|}{ displaced } & \multicolumn{3}{|c|}{ housedam } & \multirow[b]{2}{*}{ t-test } & \multirow[b]{2}{*}{ all } \\
\hline & 0 & 1 & t-test & 0 & 1 & & & 0 & 1 & t-test & 0 & 1 & & & 0 & 1 & t-test & 0 & 1 & & \\
\hline Being female & 0.472 & 0.500 & & 0.484 & 0.454 & n.s. & 0.477 & & & & & & & & & & & & & & \\
\hline Speaking Indonesian & 0.575 & 0.720 & 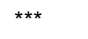 & 0.584 & 0.632 & n.s. & 0.597 & 0.577 & 0.701 & ** & 0.580 & 0.634 & n.s. & 0.594 & 0.574 & 0.738 & 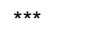 & 0.589 & 0.631 & & 0.599 \\
\hline Speaking Portuguese & 0.028 & 0.033 & n.s. & 0.030 & 0.027 & n.s. & 0.029 & 0.032 & 0.028 & n.s. & 0.031 & 0.035 & n.s. & 0.032 & 0.024 & 0.037 & n.s. & 0.029 & 0.018 & & 0.026 \\
\hline $\mathrm{HH}$ head is a farmer & 0.646 & 0.556 & ** & 0.623 & 0.659 & n.s. & 0.632 & 0.649 & 0.570 & n.s. & 0.639 & 0.634 & n.s. & 0.638 & 0.642 & 0.542 & * & 0.606 & 0.690 & ${ }^{* *}$ & 0.627 \\
\hline Education grade of $\mathrm{HH}$ head & 3.114 & 3.651 & n.s. & 3.332 & 2.783 & ** & 3.193 & 2.954 & 3.210 & n.s. & 3.099 & 2.685 & n.s. & 2.989 & 3.293 & 4.084 & n.s. & 3.581 & 2.899 & * & 3.415 \\
\hline Education grade of the mother & 1.870 & 2.785 & $* \star \star$ & 2.200 & 1.435 & *** & 2.005 & 1.827 & 2.252 & n.s. & 2.061 & 1.406 & ** & 1.887 & 1.918 & 3.318 & $* \star \star$ & 2.348 & 1.470 & $* \star \star$ & 2.135 \\
\hline Education grade of the father & 2.824 & 3.495 & * & 3.037 & 2.589 & ** & 2.923 & 2.802 & 2.869 & n.s. & 2.944 & 2.446 & n.s. & 2.812 & 2.848 & 4.121 & $* *$ & 3.136 & 2.762 & & 3.045 \\
\hline Living in urban areas & 0.402 & 0.533 & $* \star \star$ & 0.419 & 0.427 & n.s. & 0.421 & 0.396 & 0.551 & 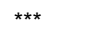 & 0.413 & 0.431 & n.s. & 0.418 & 0.409 & 0.514 & ** & 0.426 & 0.423 & & 0.425 \\
\hline Per capita montly $\mathrm{HH}$ expenditure & 238963 & 262113 & n.s. & 244940 & 234904 & n.s. & 242379 & 250901 & 249806 & n.s. & 245971 & 263914 & n.s. & 250746 & 225635 & 274421 & * & 243843 & 200024 & $\star \star \star$ & 233189 \\
\hline N & 1236 & 214 & & 1080 & 370 & & 1450 & 652 & 107 & & 557 & 202 & & 759 & 584 & 107 & & 523 & 168 & & 691 \\
\hline \multicolumn{22}{|c|}{ Only children aged 10-12 (labour market characteristics) } \\
\hline Has worked in the past 7 days & 0.063 & 0.088 & n.s. & 0.070 & 0.056 & n.s. & 0.067 & 0.054 & 0.167 & $\star \star$ & 0.071 & 0.063 & n.s. & 0.069 & 0.073 & 0.019 & ** & 0.070 & 0.048 & n.s. & 0.065 \\
\hline Working hours & 1.468 & 2.098 & n.s. & 1.722 & 1.084 & n.s. & 1.560 & 1.117 & 4.292 & ** & 1.582 & 1.406 & n.s. & 1.536 & 1.857 & 0.148 & $\star \star \star *$ & 1.868 & 0.711 & n.s. & 1.585 \\
\hline Has done domestic chores & 0.902 & 0.912 & n.s. & 0.897 & 0.922 & n.s. & 0.903 & 0.889 & 0.854 & n.s. & 0.888 & 0.875 & n.s. & 0.885 & 0.916 & 0.963 & n.s. & 0.907 & 0.976 & n.s. & 0.924 \\
\hline$N$ & 602 & 102 & & 525 & 179 & & 704 & 316 & 48 & & 268 & 96 & & 364 & 286 & 54 & & 257 & 83 & & 340 \\
\hline
\end{tabular}




\begin{tabular}{|c|c|c|c|c|c|c|c|c|c|c|c|c|}
\hline & \multicolumn{4}{|c|}{ All } & \multicolumn{4}{|c|}{ Boys } & \multicolumn{4}{|c|}{ Girls } \\
\hline & $(0,0)$ & $(0,1)$ & $(1,0)$ & $(1,1)$ & $(0,0)$ & $(0,1)$ & $(1,0)$ & $(1,1)$ & $(0,0)$ & $(0,1)$ & $(1,0)$ & $(1,1)$ \\
\hline Being female & 0.474 & 0.594 & 0.468 & 0.424 & & & & & & & & \\
\hline Speaking Indonesian & 0.568 & 0.750 & 0.603 & 0.695 & 0.568 & 0.744 & 0.612 & 0.676 & 0.569 & 0.754 & 0.593 & 0.720 \\
\hline Speaking Portuguese & 0.030 & 0.021 & 0.020 & 0.042 & 0.033 & 0.000 & 0.030 & 0.044 & 0.028 & 0.035 & 0.008 & 0.040 \\
\hline $\mathrm{HH}$ head is a farmer & 0.645 & 0.396 & 0.647 & 0.686 & 0.658 & 0.385 & 0.612 & 0.676 & 0.631 & 0.404 & 0.686 & 0.700 \\
\hline Education grade of $\mathrm{HH}$ head & 3.107 & 5.646 & 3.143 & 2.000 & 2.923 & 5.436 & 3.075 & 1.894 & 3.311 & 5.789 & 3.220 & 2.140 \\
\hline Education grade of the mother & 1.979 & 4.469 & 1.444 & 1.415 & 1.917 & 3.974 & 1.478 & 1.265 & 2.047 & 4.807 & 1.407 & 1.620 \\
\hline Education grade of the father & 2.795 & 5.521 & 2.937 & 1.847 & 2.776 & 5.179 & 2.903 & 1.544 & 2.815 & 5.754 & 2.975 & 2.260 \\
\hline Living in urban areas & 0.397 & 0.646 & 0.421 & 0.441 & 0.394 & 0.667 & 0.403 & 0.485 & 0.401 & 0.632 & 0.441 & 0.380 \\
\hline Per capita montly HH expenditure & 237763 & 318506 & 243646 & 216234 & 242403 & 293348 & 283746 & 224832 & 232604 & 335719 & 198109 & 204542 \\
\hline$N$ & 984 & 96 & 252 & 118 & 518 & 39 & 134 & 68 & 466 & 57 & 118 & 50 \\
\hline \multicolumn{13}{|c|}{ Only children aged 10-12 (labor market characteristics) } \\
\hline Has worked in the past 7 days & 0.068 & 0.093 & 0.042 & 0.085 & 0.060 & 0.235 & 0.031 & 0.129 & 0.078 & 0.000 & 0.055 & 0.036 \\
\hline Working hours & 1.678 & 2.209 & 0.625 & 2.017 & 1.311 & 5.588 & 0.369 & 3.581 & 2.078 & 0.000 & 0.927 & 0.286 \\
\hline Has done domestic chores & 0.900 & 0.860 & 0.908 & 0.949 & 0.896 & 0.765 & 0.862 & 0.903 & 0.905 & 0.923 & 0.964 & 1.000 \\
\hline$N$ & 482 & 43 & 120 & 59 & 251 & 17 & 65 & 31 & 231 & 26 & 55 & 28 \\
\hline
\end{tabular}

Source: Authors' computations using TLSS (2001).

Note: ${ }^{*} p<0.10,{ }^{* \star} p<0.05,{ }^{\star \star \star} p<0.01$. n.s. $=$ not statistically significant

Note: $(0,0)=$ not affected; $(0,1)$ only displaced; $(1,0)$ only house damaged completely; $(1,1)$ affected by both shocks. 
The economics literature on violent conflict usually employs geographical correlates of violence at a suitable level of analysis (village or district) as instruments for self-reported conflict information. Unfortunately, the codes for sampled villages and districts in Timor Leste were not disclosed in the 2001 TLSS, and we are unable to employ this strategy in the analysis. We only have suitable information at the area level. As Timor Leste is divided into only five areas, the IV estimator is not reliable at that level. However, we are able to make use of the DID estimation outlined above to correct for potential endogeneity problems. To this purpose, we take advantage of the panel nature of the data in order to employ a fixed effect estimator methodology (FE, hereafter) ${ }^{16}$ In this way, the effect of a variation of the specified covariates is the same for all individuals and over all periods of time, but the average effect for each individual $i$ can be different from individual $j$. The FE estimator allows us to wipe out all time-invariant unobserved characteristics, which may be correlated with the conflict measure and with our dependent variable. Therefore, we take advantage of the longitudinal design of our 'ad hoc' panel data in order to eliminate individual unobserved heterogeneity. The FE model does not account for time-variant omitted variables. Our specification includes thus year dummies that allow us to control for this unobserved timevariant heterogeneity.

In addition to potential sample biases, the results may also contain identification biases. One potential threat to our identification strategy is that trends in education before the 1999 violence were not 'parallel' between affected and not affected group. The violation of this assumption would lead to wrong conclusions because pre-existing trends could then be driving post-conflict education outcomes. We have examined the average educational grade achieved before the 1999 violence of affected and not affected groups of individuals. Figures $3.3 \mathrm{a}$ and 3.3b (see over) show that trends in education levels of affected and not affected groups were parallel for cohorts which were not exposed to the 1999 conflict during primary school years and were old enough in 1999 to have completed at least their primary school level. ${ }^{17}$ The graphs are done by estimating separate kernel-weighted local polynomial regressions of attained grade of education against age using an Epanechnikov kernel. Given the in Figures $3.3 \mathrm{a}$ and $3.3 \mathrm{~b}$, it is unlikely that pre-existing trends may be driving our postconflict outcomes.

\footnotetext{
16 We think that a FE model is more appropriate in our case than a random effect model as we would have to assume that the unobserved component of the individual fixed effects and the other covariates specified in the equation are uncorrelated. This assumption is likely to be violated in our specific case and RE estimates would be biased. We have performed the Hausman test (1978) that verifies whether the RE estimator is statistically different to FE estimator, and cannot reject the null hypothesis of the test that these effects are correlated with the other variables in the model and that ultimately the FE model is preferable.

17 We do not include cohorts born after 1986 as these individuals (our treated cohort) were still in primary school age in 1999. Therefore their education attainment would be censored.
} 
Figure 3.3a Pre-conflict trends in education levels, displacement

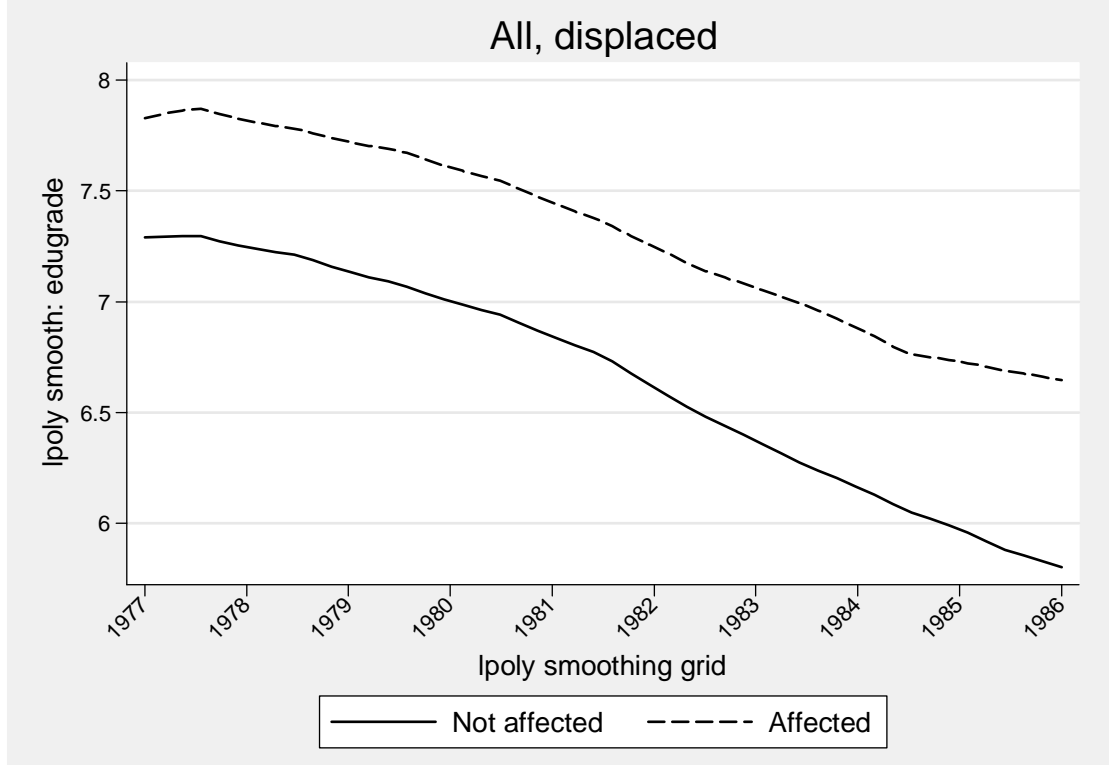

Source: Authors' own computations using TLSS (2001).

Figure 3.3b Pre-conflict trends in education levels, house completely damaged

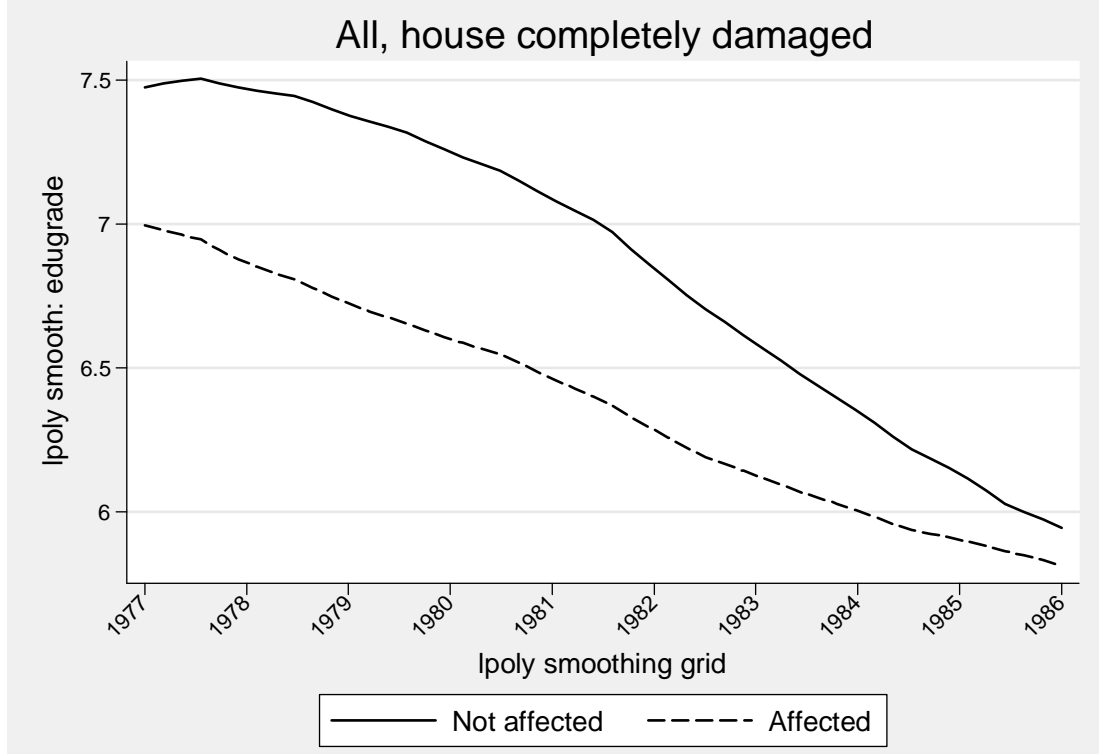

Source: Authors' own computations using TLSS (2001). 


\subsection{Identification strategy: the impact of violence on primary school completion in 2007}

The second aim of this paper is to analyse the longer term effect of the conflict on primary school attainment in 2007. In this section, we focus on the analysis of the impact of the 1999 violence on educational attainment in 2007 , and compare this with the impact of peaks of violence during the earlier stages of the conflict on education attainment outcomes among boys and girls living in areas of intense conflict. We examine also the overall impact of the 25 years of conflict on educational outcomes. This analysis allows us to consider the full long-term impact of the conflict on educational outcomes of different generations of children in Timor Leste.

\subsubsection{The educational impact of the 1999 wave of violence}

We exploit variation in the number of killings over time and across districts to identify conflict affected individuals. Our intention here is to analyse whether individuals exposed to the violence during their primary school age show different primary school completion rates eight years after the end of the war, relative to those not affected by the conflict. The outcome variable in which we are interested is whether individuals completed primary school in 2007.

Figure 3.4 shows average primary school attainment for all individuals in our sample. The graph shows an increasing trend in primary school completion across cohorts and a progressive reduction of the gender gap. The gap among the younger cohort (those born after 1987) is almost zero. The drop in the curve for the younger cohort confirms the presence of significant delays in school attendance.

Figure 3.4 Average primary school completion by gender, 2007

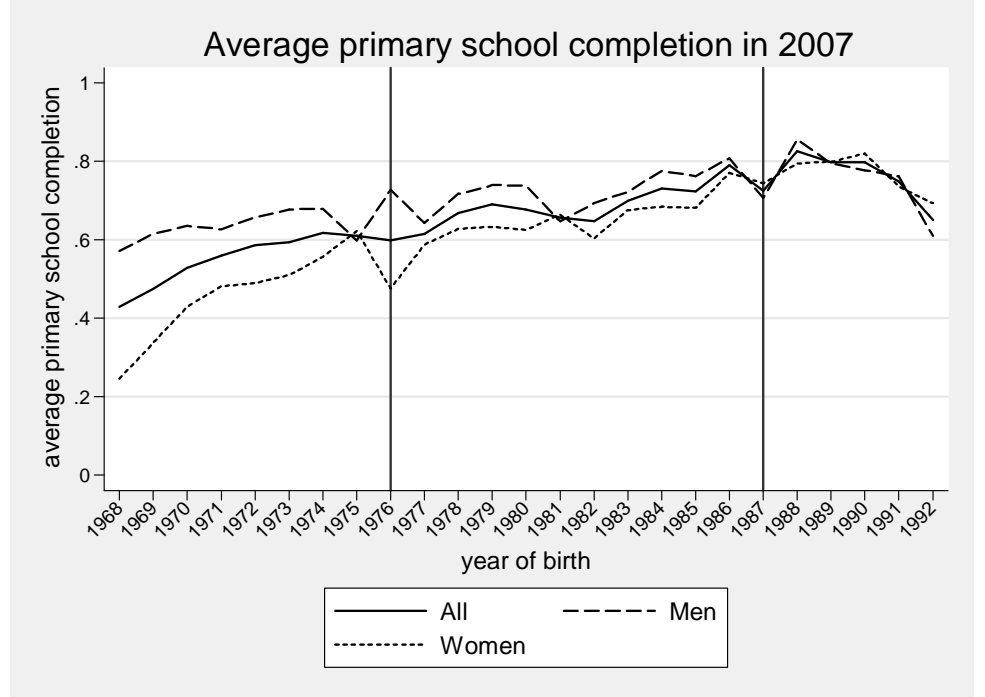

Source: Authors' own computations using TLSS 2007.

For the purpose of this analysis, we use the TLSS 2007 dataset and the HRVD dataset contained in the CAVR data publication. As explained in Section 3 (page 14), the HRVD dataset contains data on the number of human rights violations occurred since the start of the conflict in 1975 until its end in 1999 for each district. The types of violations recorded are killings, deaths due to deprivation and disappearances. We use only the number of killings to identify years and districts affected by the conflict. We exclude the deaths due to deprivation because the districts in which this occurred may very likely not be those where the conflict was most intense, but were simply places were the victims were hiding as a consequence of escaping from the troops, and died for starvation. In addition, since killings are less likely to affect entire families than deaths due to deprivation, there is a lower underreporting bias 
attached to the former measure relative to the latter one (Silva and Ball 2006). We also exclude disappearances as, according to HRVD data, they do not show enough time and geographical variation in order to identify individuals more or less exposed to the conflict. We believe that the number of killings proxies quite well the intensity of the conflict across time and space as their occurrence largely tracked the movements of the Indonesian military operations. The other two types of violations do not seem to show the same pattern (Silva and Ball 2006). For the same reason, we believe that it proxies quite well the destruction of houses and infrastructure and the displacement of people given the way in which the last wave of violence occurred (i.e. the scorch-earth technique employed by Indonesian troops as they moved towards West Timor).

We define districts and years of 'high intensity conflict' as those in which the number of killings in that year and district are above a certain threshold. We decided not to use the variable as a continuous measure but as a dichotomous one, because its distribution is highly right-skewed (as shown in Figure 3.5, which shows a kernel density plot of the number of killings). Also, given the nature of the data reported, and the likelihood that there is an underreporting in the number of killings as explained in the previous section, the actual value is not meaningful in itself. Indeed what we are interested in most is exploiting its variation over time and across space.

\section{Figure 3.5 Kernel density plot of number of killings}

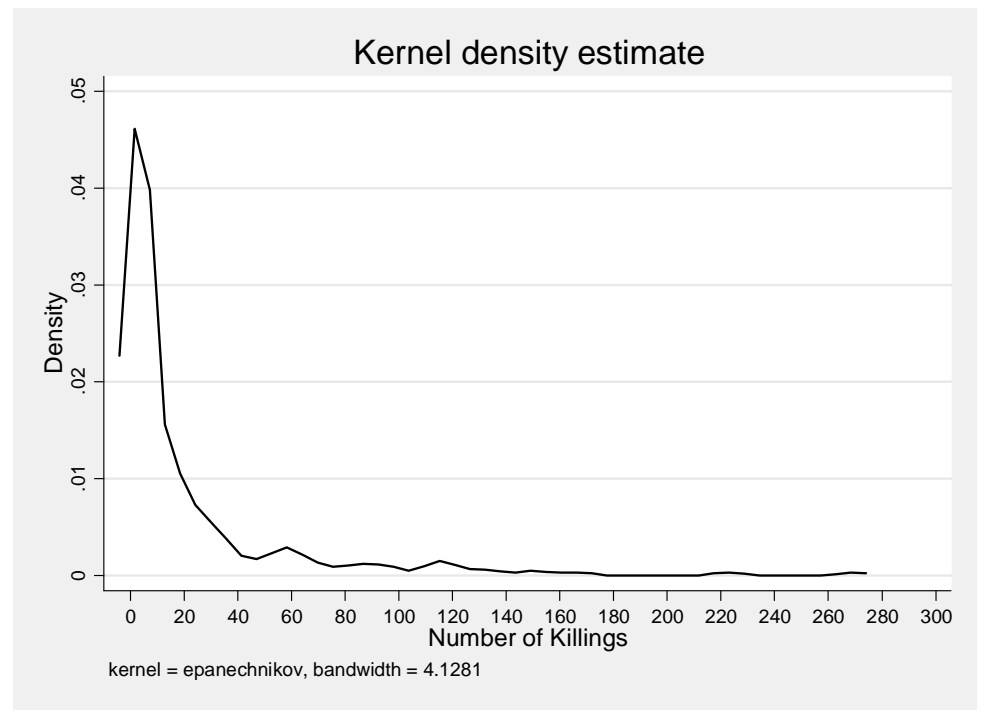

Source: Authors' own computations using CAVR (2006).

We define the violence intensity threshold as the mean of the number of killings plus one standard deviation (as the majority of observations are within one standard deviation of the mean, and nearly all within two standard deviations of the mean). The variable that we obtain is a dummy variable that equals 1 if the number of killings in a particular year and district is above the threshold. In this way, we are able to clearly distinguish years and districts in which the conflict was most intense from those in which it was less intense.

We exploit this variation over time and across districts to identify individuals exposed to the conflict. The dataset provides information on the year and district of birth of each individual. We assume that the district of birth is the district where the child has attended school at the time of the violent events in 1999. We then merge the variable that identifies the intensity of the conflict in each district and year to the district of birth of each individual. Using the information on the year of birth of each individual, we define the six years in which individuals 
are supposed to have attended primary school. ${ }^{18}$ We know that, under the Indonesian schooling system, children were supposed to enter school by age 7 and completed the first 6 grades by age 12. We are therefore able to assign the level of violence to each individual depending on whether his district of birth and schooling years coincides with a high or low conflict intensity district and year.

We have constructed a set of dummies that equal to 1 if the violence is above the threshold in the district of birth and in the year in which the individual was supposed to attend his primary school. Each dummy will assume zero value if either the district of birth or the primary school year is not of high intensity as defined by the threshold above. We have obtained a set of six dummies, which indicate whether individuals were exposed or not to the conflict in each specific year of primary school. The final variable that we construct is the sum of these six dummies. This can range from 0 to 6 if no or all six primary school years were exposed to the conflict. The variable is defined as follows:

$$
V_{t}^{i}=\Sigma_{a=7}^{12} v_{t+a}^{j}
$$

where $v_{t+a}^{l}$ will assume value 1 if the individual was born in a district of violence and was of primary school age in periods in which the conflict was more intense. More specifically, $j$ is the district of birth, $t$ is the year of birth and $a$ is the primary school age (from 7 to 12).

Table 3.4 shows the years (in bold and grey) in which, depending on the year of birth, individuals were affected by the conflict during the primary school years. The years in which the conflict was most intense, as defined by our threshold, are those between 1976-1979, then 1983 and 1999. This evidence coincides with what we know on the history of the conflict (CAVR 2005).

Table 3.4 Years in which individuals were supposed to attend primary school (by year of birth)

\begin{tabular}{|c|c|c|c|c|c|c|c|}
\hline & \multirow{3}{*}{$\begin{array}{l}\text { Age } \\
\text { Grade }\end{array}$} & \multicolumn{6}{|c|}{ Years in which individuals were supposed to attend primary school } \\
\hline & & 7 & 8 & 9 & 10 & 11 & 12 \\
\hline & & 1 & 2 & 3 & 4 & 5 & 6 \\
\hline \multicolumn{8}{|l|}{ Year of birth } \\
\hline 1963 & & 1970 & 1971 & 1972 & 1973 & 1974 & 1975 \\
\hline 1964 & & 1971 & 1972 & 1973 & 1974 & 1975 & 1976 \\
\hline 1965 & & 1972 & 1973 & 1974 & 1975 & 1976 & 1977 \\
\hline 1966 & & 1973 & 1974 & 1975 & 1976 & 1977 & 1978 \\
\hline 1967 & & 1974 & 1975 & 1976 & 1977 & 1978 & 1979 \\
\hline 1968 & & 1975 & 1976 & 1977 & 1978 & 1979 & 1980 \\
\hline 1969 & & 1976 & 1977 & 1978 & 1979 & 1980 & 1981 \\
\hline 1970 & & 1977 & 1978 & 1979 & 1980 & 1981 & 1982 \\
\hline 1971 & & 1978 & 1979 & 1980 & 1981 & 1982 & 1983 \\
\hline 1972 & & 1979 & 1980 & 1981 & 1982 & 1983 & 1984 \\
\hline 1973 & & 1980 & 1981 & 1982 & 1983 & 1984 & 1985 \\
\hline 1974 & & 1981 & 1982 & 1983 & 1984 & 1985 & 1986 \\
\hline 1975 & & 1982 & 1983 & 1984 & 1985 & 1986 & 1987 \\
\hline 1976 & & 1983 & 1984 & 1985 & 1986 & 1987 & 1988 \\
\hline 1977 & & 1984 & 1985 & 1986 & 1987 & 1988 & 1989 \\
\hline 1978 & & 1985 & 1986 & 1987 & 1988 & 1989 & 1990 \\
\hline 1979 & & 1986 & 1987 & 1988 & 1989 & 1990 & 1991 \\
\hline
\end{tabular}

18 These are the years in which an individual is 'supposed' to attend school and not the years in which he actually attended as unfortunately we do not have this information. The existence of a delay in school means that the 'supposed' years might not coincide with the 'actual' years. However, given the way in which we identify our control and treatment groups we do not expect this difference to affect our results. 


\begin{tabular}{|c|c|c|c|c|c|c|}
\hline 1980 & 1987 & 1988 & 1989 & 1990 & 1991 & 1992 \\
\hline 1981 & 1988 & 1989 & 1990 & 1991 & 1992 & 1993 \\
\hline 1982 & 1989 & 1990 & 1991 & 1992 & 1993 & 1994 \\
\hline 1983 & 1990 & 1991 & 1992 & 1993 & 1994 & 1995 \\
\hline 1984 & 1991 & 1992 & 1993 & 1994 & 1995 & 1996 \\
\hline 1985 & 1992 & 1993 & 1994 & 1995 & 1996 & 1997 \\
\hline 1986 & 1993 & 1994 & 1995 & 1996 & 1997 & 1998 \\
\hline 1987 & 1994 & 1995 & 1996 & 1997 & 1998 & 1999 \\
\hline 1988 & 1995 & 1996 & 1997 & 1998 & 1999 & 2000 \\
\hline 1989 & 1996 & 1997 & 1998 & 1999 & 2000 & 2001 \\
\hline 1990 & 1997 & 1998 & 1999 & 2000 & 2001 & 2002 \\
\hline 1991 & 1998 & 1999 & 2000 & 2001 & 2002 & 2003 \\
\hline 1992 & 1999 & 2000 & 2001 & 2002 & 2003 & 2004 \\
\hline
\end{tabular}

Source: Authors' own computations.

Table 3.5 shows the distribution of the violence variable by year of birth and district. It shows which are the cohorts and the districts exposed to the violence. Each cell shows the number of primary school years exposed to the conflict.

In order to estimate the effect of the 1999 violence on school completion in 2007 we include in our sample individuals born between 1977 and 1992. Those born in 1992 are supposed to have started school in 1999, so at the end of the conflict. We include individuals born up until 1992 as they are 15 years old in 2007 and so supposed to have completed at least primary school. We do not include individuals born after this year as they might have not completed primary school yet. ${ }^{19}$ As Tables 3.4 and 3.5 show, individuals born between 1977 and 1986 should not have been affected by violence during their primary school years.

\section{Table 3.5 Number of years of exposure to the conflict in each district and year}

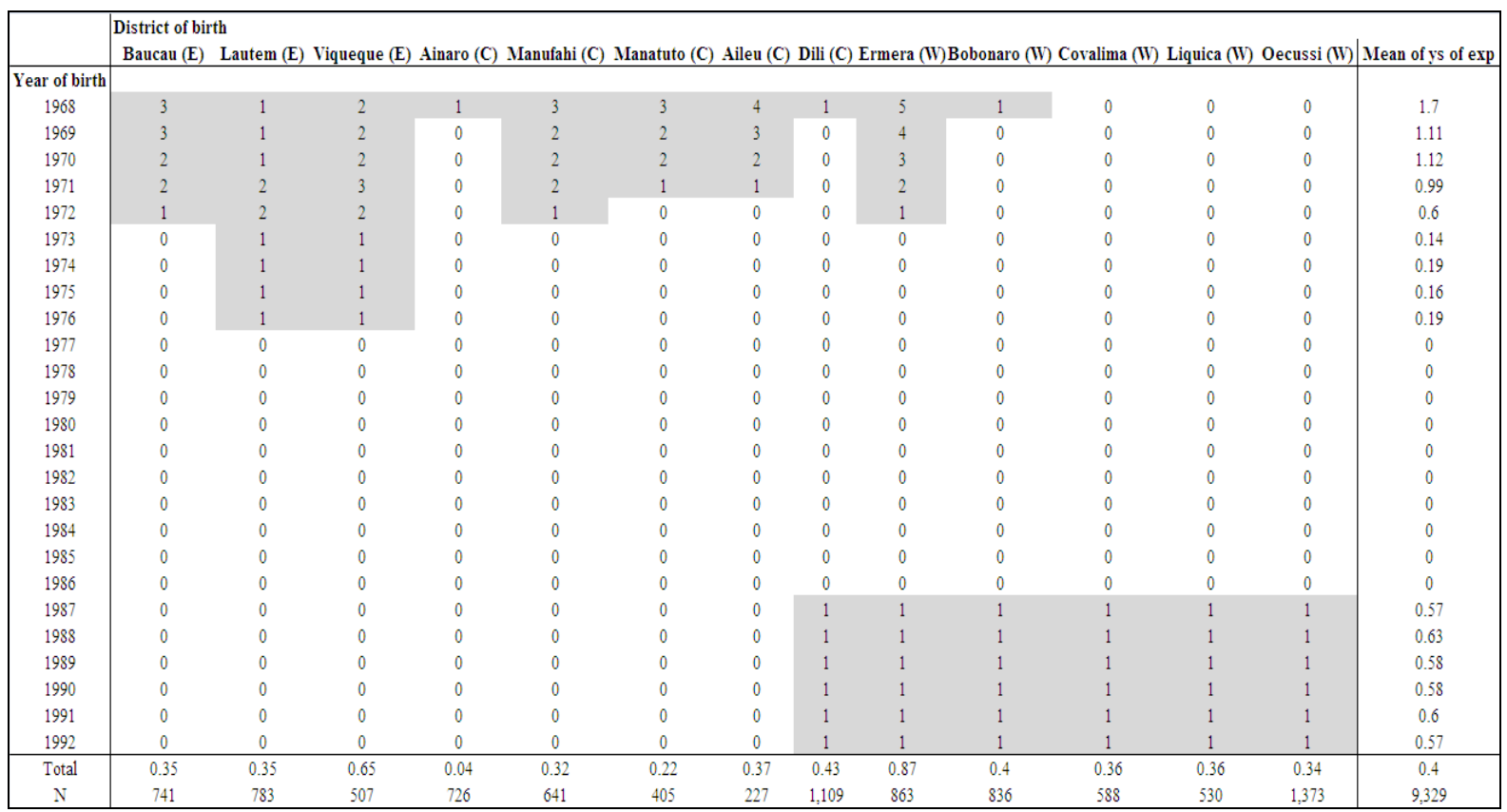

Source: Authors' own computations using CAVR (2006).

According to our data, there is a significant percentage of individuals in our sample (the 39 per cent, mostly born in 1991 and 1992) who are still attending primary school despite being old enough to have completed primary school. This testifies the high delay in school. We are aware of a potential right censoring in our dependent variable but we believe that our main results would remain unchanged if we were able to account for this. In addition in our empirical strategy we are going to provide some insights on this issue by looking at the separate effect between younger and older individuals. 


\subsubsection{The educational impact of earlier peaks of violence and of the overall conflict}

Our second objective is to analyse the effect of the early years of the conflict on school completion in 2007 in order to investigate whether there are any significant differences in the educational impact of the conflict in later and in earlier waves of the conflict. This will allow us to understand the full impact of 25 years of violent conflict on several generations of Timorese children, as well as analyse whether violence exercised at different points of the conflict (and driven by different objectives) may have had different effects on human capital outcomes.

Aside from 1999, the Timor Leste conflict was very intense between 1975 and 1979 and again in 1983. According to our definition of violence intensity, the other years up until 1999 were of very low intensity. In order to analyse the impact of earlier peaks of violence, we focus our analysis on a sample of individuals born between 1968 and 1984. Those born in 1968 were supposed to have started their primary school in 1975, so exactly at the start of the conflict. Even though those born between 1963 and 1967 had at least one year of primary school exposed to the conflict, we do not consider those born before 1968 because the schooling system was very different before the Indonesian troops invaded Dili in 1975. We also do not include individuals born between 1985 and 1986 as these were between 13 and 14 in 2007. Given the significant delay in school entry in Timor Leste, those born in 1985 and 1986 could still have been affected by the violence in $1999 .{ }^{20}$ We have estimated specifications including these individuals. The results are mostly unchanged, so we decided not to include them, but they are available upon request.

One interesting issue when analyzing the effect of the first years of the violence, is that individuals could have been affected by the violence for more than one year, as violence was highly intense between 1975 and 1979 and in 1983. So, differently from the analysis of 1999 violence, we estimate here a model in which the measure of violence intensity is a continuous variable. This variable allows us to examine the effects of whether the individual was exposed or not to the violence, and it also informs us on the effects of exposure to violence during a number of primary school years. This analysis will provide insights not only on the effect of being exposed or not to violence, but also on the length of exposure to the conflict.

Finally, we assess also the effect of the whole conflict on school attainment in 2007. To this purpose, we take into account a sample of individuals born between 1968 and 1992 . This will allow us to calculate the average educational effect of exposure to any period of the conflict for boys and girls in different age groups.

\subsubsection{Empirical strategy and descriptive statistics}

In order to estimate the effect of the conflict on primary school completion in 2007 , we estimate the following equation:

$$
G_{i j t}=\beta v_{t}^{i}+a_{j}+\alpha_{i}+\alpha_{j}^{2}+X_{i}^{t} \gamma+s_{i j t}
$$

where $G_{i j t}$ is the dependent variable and refers to primary school completion for individual $i$ born in district $j$ and in year $t$. The variable we use to identify school completion is a binary variable equal to 1 if the individual attained grade six or more of schooling and 0 otherwise. The main reason to use a binary variable as the dependent variable in place of a continuous one up to grade six is that this variable allows us to detect peaks in school achievements mostly at grade six, given that it is the completion year of primary school (Shemyakina 2011).

\footnotetext{
20 We have conducted some placebo tests which will show that this cohorts were not affected neither by the early years of the conflict nor by the 1999 violence.
} 
In our estimated model, all standard errors are clustered at the year and district of birth level. The term $X_{i}^{l}$ is a vector of household characteristics. In order to control for any household specific characteristic, we included as explanatory variables the education of the household head (which should be related to pre-war characteristics of the household) and whether he/she is a farmer. We interpret these variables as proxies for the income level of the family. We control for whether the respondent is female, but have also estimated the above model for boys and girls, separately. The term $V_{\varepsilon}^{j}$ identifies individuals exposed to the conflict. $\beta$ is our parameter of interest, indicating whether being affected by the conflict (or whether an additional year of exposure to the conflict) during primary school affects the probability of primary school completion after the conflict ended as compared to an individual that was not exposed to the conflict during his primary school age. The two parameters $\alpha_{i}$ and $\alpha_{t}$ are, respectively, dummies for the districts of birth and the years of birth. The term $\alpha_{j} t$ represents district-specific linear trends. ${ }^{21}$

We provide some descriptive statistics on the outcome variable among exposed and not exposed individuals. Table 3.6 shows the average primary school completion in 2007 for individuals exposed and not exposed to the conflict as identified by our measure of violence intensity discussed above. We look at these averages for the three samples we consider in our analysis: boys and girls separately (panel A), exposure to violence during the first three grades of primary school (panel B) and exposure to violence during the last three grades of primary school (panel C).

Table 3.6 Average primary school completion in 2007, by exposed and not exposed

Panel A

\begin{tabular}{|cccc|ccc|ccc|}
\hline & $\begin{array}{c}(1) \\
\text { Not Exp,All }\end{array}$ & $\begin{array}{c}(2) \\
\text { Exp,All }\end{array}$ & ttest & $\begin{array}{c}(3) \\
\text { Not Exp,Boys }\end{array}$ & $\begin{array}{c}(4) \\
\text { Exp,Boys }\end{array}$ & ttest & Not Exp,Girls & $\begin{array}{c}(5) \\
\text { Exp, Girls }\end{array}$ & ttest \\
\hline Sample 1977-1992 & 0.725 & 0.724 & n.s & 0.752 & 0.709 & $\star *$ & 0.698 & 0.739 & $\star \star$ \\
& $(0.006)$ & $(0.013)$ & & $(0.008)$ & $(0.020)$ & & $(0.008)$ & $(0.017)$ & \\
\hline Sample 1968-1984 & 0.624 & 0.572 & $\star \star *$ & 0.680 & 0.658 & n.s. & 0.569 & 0.472 & $* * *$ \\
& $(0.007)$ & $(0.023)$ & & $(0.010)$ & $(0.032)$ & & $(0.009)$ & $(0.034)$ & \\
\hline Sample 1968-1992 & 0.679 & 0.674 & n.s & 0.720 & 0.692 & $\star *$ & 0.636 & 0.654 & n.s. \\
& $(0.005)$ & $(0.009)$ & & $(0.007)$ & $(0.013)$ & & $(0.006)$ & $(0.013)$ & \\
\hline
\end{tabular}

Panel B- Average primary school completion in 2007, by exposed and not exposed in first three grades

\begin{tabular}{|c|c|c|c|c|c|c|c|c|c|}
\hline & $\begin{array}{c}\text { (1) } \\
\text { Not Exp,All } \\
\text { b/se }\end{array}$ & $\begin{array}{c}\text { (2) } \\
\text { Exp,All } \\
\text { b/se }\end{array}$ & ttest & $\begin{array}{l}(3) \\
\text { Not Exp,Boys } \\
\text { b/se }\end{array}$ & $\begin{array}{c}\text { (4) } \\
\text { Exp,Boys } \\
\text { b/se }\end{array}$ & ttest & $\begin{array}{l}\text { (5) } \\
\text { Not Exp,Girls } \\
\text { b/se }\end{array}$ & $\begin{array}{c}\text { (6) } \\
\text { Exp, Girls } \\
\text { b/se }\end{array}$ & ttest \\
\hline Sample 1977-1992 & $\begin{array}{c}0.731 \\
(0.005) \\
\end{array}$ & $\begin{array}{c}0.692 \\
(0.019) \\
\end{array}$ & *夫 & $\begin{array}{c}0.751 \\
(0.008) \\
\end{array}$ & $\begin{array}{c}0.673 \\
(0.029) \\
\end{array}$ & 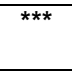 & $\begin{array}{c}0.709 \\
(0.007) \\
\end{array}$ & $\begin{array}{c}0.711 \\
(0.025) \\
\end{array}$ & n.s. \\
\hline Sample 1968-1984 & $\begin{array}{c}0.623 \\
(0.007) \\
\end{array}$ & $\begin{array}{c}0.571 \\
(0.024) \\
\end{array}$ & 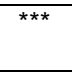 & $\begin{array}{c}0.679 \\
(0.010) \\
\end{array}$ & $\begin{array}{c}0.659 \\
(0.032) \\
\end{array}$ & n.s. & $\begin{array}{c}0.567 \\
(0.010)\end{array}$ & $\begin{array}{c}0.471 \\
(0.035) \\
\end{array}$ & *** \\
\hline Sample 1968-1992 & $\begin{array}{c}0.687 \\
(0.004)\end{array}$ & $\begin{array}{c}0.637 \\
(0.012)\end{array}$ & 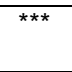 & $\begin{array}{c}0.723 \\
(0.006)\end{array}$ & $\begin{array}{c}0.666 \\
(0.016)\end{array}$ & 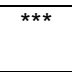 & $\begin{array}{c}0.650 \\
(0.006)\end{array}$ & $\begin{array}{c}0.605 \\
(0.016)\end{array}$ & 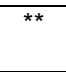 \\
\hline
\end{tabular}

Panel C- Average primary school completion in 2007, by exposed and not exposed in last three grades

\begin{tabular}{|c|c|c|c|c|c|c|c|c|c|}
\hline & $\begin{array}{c}\text { (1) } \\
\text { Not Exp,All } \\
\text { b/se }\end{array}$ & $\begin{array}{c}(2) \\
\text { Exp,All } \\
\text { b/se }\end{array}$ & ttest & $\begin{array}{c}\text { (3) } \\
\text { Not Exp,Boys } \\
\text { b/se }\end{array}$ & $\begin{array}{c}(4) \\
\text { Exp,Boys } \\
\text { b/se }\end{array}$ & ttest & $\begin{array}{l}\text { (5) } \\
\text { Not Exp,Girls } \\
\text { b/se }\end{array}$ & $\begin{array}{c}6) \\
\text { Exp, Girls } \\
\text { b/se }\end{array}$ & ttest \\
\hline Sample 1977-1992 & $\begin{array}{c}0.719 \\
(0.005)\end{array}$ & $\begin{array}{c}0.759 \\
(0.018)\end{array}$ & ** & $\begin{array}{c}0.738 \\
(0.008)\end{array}$ & $\begin{array}{c}0.749 \\
(0.028)\end{array}$ & n.s. & $\begin{array}{c}0.700 \\
(0.007)\end{array}$ & $\begin{array}{c}0.769 \\
(0.023)\end{array}$ & *** \\
\hline Sample 1968-1984 & $\begin{array}{c}0.622 \\
(0.007)\end{array}$ & $\begin{array}{c}0.524 \\
(0.037)\end{array}$ & 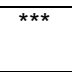 & $\begin{array}{c}0.680 \\
(0.010)\end{array}$ & $\begin{array}{c}0.634 \\
(0.051)\end{array}$ & n.s. & $\begin{array}{c}0.564 \\
(0.009)\end{array}$ & $\begin{array}{c}0.385 \\
(0.054)\end{array}$ & *** \\
\hline Sample 1968-1992 & $\begin{array}{c}0.675 \\
(0.004)\end{array}$ & $\begin{array}{c}0.690 \\
(0.014)\end{array}$ & n.s. & $\begin{array}{c}0.711 \\
(0.006)\end{array}$ & $\begin{array}{c}0.713 \\
(0.021)\end{array}$ & n.s. & $\begin{array}{c}0.638 \\
(0.006)\end{array}$ & $\begin{array}{c}0.664 \\
(0.019)\end{array}$ & n.s. \\
\hline
\end{tabular}

Source: Authors' computations using TLSS (2007).

21 We have also estimated our equation including either cubic district trend or square roots district trend to account for a non linear trend across districts. We do not find any difference in the estimates and therefore we only show the results which include a linear district trend. 
If we concentrate on the first sample (1977-1992), we see that exposed boys show a lower attainment rate than not exposed ones, while the contrary is true for girls. Interestingly however, these differences seems to be stronger for boys affected during the first three grades (younger), and for girls affected in the last three grades (older). Looking at these averages over the sample 1968-1984, we notice that exposed individuals show a lower completion rate than those not exposed to violence. This difference is particularly clear for girls, mostly for those exposed to violence during the last three grades of primary school (older girls).

\subsubsection{Potential sample biases and identification concerns}

One concern with our empirical strategy is whether there is a systematic relation between the intensity of the violence across districts and pre-conflict education levels at the district level (i.e. whether pre-conflict education conditions predict the likelihood of conflict occurrence in specific districts). The existence of time-varying unobservables which are correlated with both the outcome and the conflict variables would bias our results. The inclusion of district effects allows us however to account for time-invariant differences in education levels across districts. By including district specific time trends, we account for any difference in trends across districts and hence for any time-varying characteristics in a given district.

In order to check whether there is a correlation between pre-conflict levels and trends in education and conflict occurrence in specific districts, we have in addition carried placebo tests on cohorts that supposedly were not exposed to the conflict during their primary school age.

As the geographical variation of the conflict differs between the early years and the 1999 year, we have estimated two separate models by defining different war districts and 'placebo' cohorts. On the basis of the definition outlined above of affected or not affected districts (see Table 3.5) ,we have constructed two war district dummies equal to 1 if the individual district of birth is in one of the district affected by the conflict during the early years of the violence or during the 1999 violence, respectively, and zero otherwise. ${ }^{22}$

The first placebo test concentrates on the early years of the conflict. Unfortunately, we are not able to look at pre-conflict cohorts because, as explained above, the cohort born before 1968 was exposed to a different school system. Therefore, we define as exposed 'placebo' cohorts those born between 1977 and 1980 and compare them to those born between 1981 and $1984 .{ }^{23}$ As a further check, we have also analysed violence exposure for cohorts born between 1977 and 1981, and compared them to those born between 1982 and $1986 .{ }^{24}$ We estimated a simple difference-in-differences model in which we focus on the coefficient over the interaction term between the war cohort and war district dummies. We expect to find no effect of 'exposure' of cohorts who were not of primary school age, but were born in districts affected by the conflict, on their primary school attainment in 2007. We have done the same analysis with a focus on the 1999 violence. Those born between 1982 and 1986 were not of school age in 1999. We compared their exposure to that of those born between 1977 and 1981 in war and non war districts.

The results in Table 3.7 show that cohorts who were not supposed to be of primary school age during the conflict years but born in conflict affected districts do not show a different

\footnotetext{
22 The districts most affected by violence in the earlier years of the conflict are Baucau, Lautem, Viqueque, Ainaro, Manufahi, Manatuto, Aileu,Dili, Ermera, Bobonaro. Those most affected by the 1999 violence are Dili, Ermera, Bobonaro, Covalima, Liquica, Oecussi (see Table 3.5).

23 We this we must bear in mind that the 'truly' exposed cohorts to the early years of the conflict are those born between 1968 and 1976. So, in our placebo test, we look at the cohorts immediately following the 'truly' exposed ones.

$24 \quad$ Refer to Tables 3.4 and 3.5 to verify that these cohorts were supposed not to have any of their primary school years exposed to the conflict.
} 
primary school completion rate as compared to the same cohorts born in unaffected districts. This gives support to the fact that our identifying assumptions are satisfied. ${ }^{25}$

Table 3.7 Placebo test for differences in trends in education levels

\begin{tabular}{|c|c|c|c|c|c|c|c|c|c|}
\hline & \multicolumn{3}{|c|}{ Sample 1977-1984 } & \multicolumn{3}{|c|}{ Sample 1977-1986 } & \multicolumn{3}{|c|}{ Sample 1977-1986 } \\
\hline & $(1)$ & $(2)$ & (3) & (4) & (5) & (6) & $(7)$ & (8) & (9) \\
\hline & All & Boys & Girls & All & Boys & Girls & All & Boys & Girls \\
\hline $\begin{array}{l}\text { WardA* } \\
\text { coh } 1977-1980\end{array}$ & $\begin{array}{c}0.062 \\
(0.047)\end{array}$ & $\begin{array}{c}0.070 \\
(0.054)\end{array}$ & $\begin{array}{c}0.052 \\
(0.061)\end{array}$ & & & & & & \\
\hline WardA* & & & & 0.021 & 0.059 & -0.018 & & & \\
\hline ב & & & & $(0.044)$ & $(0.048)$ & $(0.058)$ & & & \\
\hline $\begin{array}{l}\text { WardB* } \\
\text { coh 1982-1986 }\end{array}$ & & & & & & & & & -0.078 \\
\hline & & & & & & & $(0.043)$ & $(0.050)$ & $(0.054)$ \\
\hline WardA & $\begin{array}{c}0.014 \\
(0.031)\end{array}$ & $\begin{array}{c}0.031 \\
(0.032)\end{array}$ & $\begin{array}{l}-0.003 \\
(0.043)\end{array}$ & $\begin{array}{c}0.040 \\
(0.030)\end{array}$ & $\begin{array}{c}0.014 \\
(0.029)\end{array}$ & $\begin{array}{c}0.063 \\
(0.043)\end{array}$ & & & \\
\hline WardB & & & & & & & $\begin{array}{l}-0.051 \\
(0.031)\end{array}$ & $\begin{array}{l}-0.037 \\
(0.040)\end{array}$ & $\begin{array}{l}-0.060 \\
(0.038)\end{array}$ \\
\hline YearBirth= 1978 & 0.047 & 0.064 & 0.030 & 0.047 & 0.065 & 0.031 & 0.049 & 0.066 & 0.034 \\
\hline & $(0.053)$ & $(0.067)$ & $(0.065)$ & $(0.054)$ & $(0.068)$ & $(0.066)$ & $(0.052)$ & $(0.071)$ & $(0.059)$ \\
\hline YearBirth= 1979 & $0.075^{\star}$ & $0.100^{\star}$ & 0.045 & 0.075 & $0.100^{\star}$ & 0.046 & 0.074 & $0.102^{\star}$ & 0.043 \\
\hline & $(0.045)$ & $(0.052)$ & $(0.070)$ & $(0.046)$ & $(0.054)$ & $(0.070)$ & $(0.045)$ & $(0.056)$ & $(0.070)$ \\
\hline YearBirth= 1980 & $0.106^{\star \star}$ & $0.143^{\star \star}$ & 0.068 & $0.101^{*}$ & $0.138^{\star *}$ & 0.065 & $0.106^{*}$ & $0.143^{* *}$ & 0.072 \\
\hline & $(0.053)$ & $(0.062)$ & $(0.057)$ & $(0.055)$ & $(0.065)$ & $(0.058)$ & $(0.057)$ & $(0.070)$ & $(0.057)$ \\
\hline YearBirth= 1981 & $0.112^{\star \star}$ & 0.095 & $0.125^{\star}$ & 0.064 & 0.039 & 0.086 & 0.068 & 0.045 & $0.089 *$ \\
\hline & $(0.054)$ & $(0.066)$ & $(0.067)$ & $(0.050)$ & $(0.065)$ & $(0.053)$ & $(0.051)$ & $(0.070)$ & $(0.052)$ \\
\hline YearBirth= 1982 & $0.131^{* \star}$ & $0.159 * *$ & 0.099 & $0.095^{\star}$ & $0.145^{* \star}$ & 0.046 & $0.090 *$ & 0.080 & 0.102 \\
\hline & $(0.052)$ & $(0.062)$ & $(0.065)$ & $(0.054)$ & $(0.064)$ & $(0.068)$ & $(0.052)$ & $(0.064)$ & $(0.063)$ \\
\hline YearBirth= 1983 & $\begin{array}{l}0.164^{\star * *} \\
(0.056)\end{array}$ & $\begin{array}{l}0.181^{* * *} \\
(0.062)\end{array}$ & $\begin{array}{l}0.142^{* *} \\
(0.071)\end{array}$ & $\begin{array}{l}0.131^{\star *} \\
(0.056)\end{array}$ & $\begin{array}{l}0.167^{* *} \\
(0.065)\end{array}$ & $\begin{array}{c}0.094 \\
(0.069)\end{array}$ & $\begin{array}{l}0.126 * * \\
(0.053)\end{array}$ & $\begin{array}{c}0.102 \\
(0.068)\end{array}$ & $\begin{array}{l}0.155^{\star *} \\
(0.062)\end{array}$ \\
\hline YearBirth= 1984 & $\begin{array}{l}0.207^{\star * *} \\
(0.054)\end{array}$ & $\begin{array}{l}0.235^{\star \star *} \\
(0.066)\end{array}$ & $\begin{array}{l}0.175^{\star \star *} \\
(0.066)\end{array}$ & $\begin{array}{c}0.172^{\star * *} \\
(0.056)\end{array}$ & $\begin{array}{c}0.221 * * * \\
(0.069)\end{array}$ & $\begin{array}{l}0.123^{*} \\
(0.070)\end{array}$ & $\begin{array}{l}0.170^{\star * *} \\
(0.055)\end{array}$ & $\begin{array}{l}0.157^{* *} \\
(0.072)\end{array}$ & $\begin{array}{c}0.187^{* * *} \\
(0.064)\end{array}$ \\
\hline YearBirth= 1985 & & & & $\begin{array}{l}0.182^{* * *} \\
(0.059)\end{array}$ & $\begin{array}{c}0.220 \text { *** } \\
(0.066)\end{array}$ & $\begin{array}{l}0.142^{\star} \\
(0.078)\end{array}$ & $\begin{array}{l}0.178^{\star * *} \\
(0.051)\end{array}$ & $\begin{array}{l}0.154^{\star *} \\
(0.064)\end{array}$ & $\begin{array}{l}0.204^{* * *} \\
(0.063)\end{array}$ \\
\hline YearBirth= 1986 & & & & $0.237^{\star \star *}$ & $0.253^{* * *}$ & $0.222^{\star \star *}$ & $0.234^{\star \star \star}$ & $0.187^{\star \star *}$ & $0.283^{\star \star \star}$ \\
\hline & & & & $(0.052)$ & $(0.061)$ & $(0.066)$ & $(0.048)$ & $(0.066)$ & $(0.057)$ \\
\hline Controls & Yes & Yes & Yes & Yes & Yes & Yes & Yes & Yes & Yes \\
\hline $\mathrm{N}$ & 2542 & 1255 & 1287 & 3402 & 1699 & 1703 & 3402 & 1699 & 1703 \\
\hline
\end{tabular}

Source: Authors' computations using TLSS 2007.

Note: $* p<0.10, * * p<0.05, * * * p<0.01$; Cluster-Robust standard errors in brackets.

Note: WardA is $=1$ if individual's district of birth is found to be a conflict affected district during the early years of conflict (19751979 and 1983) as defined by our violence measure. WardB is $=1$ if individual's district of birth is found to be a conflict affected district during the 1999 violence as defined by our violence measure.

\section{Empirical results}

\subsection{School attendance in 2001}

Table 4.1 shows the results for the impact of the two channels of violence exposure in 1999 on school attendance in the 1999/00 and 2000/01 academic years. As discussed previously, we are mostly interested in looking at the effects of the violence on school attendance in the post-conflict academic year (i.e. 2000/01). Table 4.1 reports the estimates from a fixed effect model applied to our 'ad hoc' panel dataset derived from the TLSS2001. For sake of simplicity, we have estimated a linear probability model. The analysis is disaggregated by gender and age groups. The results highlighted in bold are our main coefficients of interest.

There could still be unobservable errors in the identification of districts most affected by the violence. We have used an
instrumental variable methodology to estimate the impact of violence on school completion in order to minimise the bias and found no difference in the results discussed in the sections below. 
Table 4.1 Impact of 1999 violence on school attendance in 2001 (fixed effect model)

Panel A - Displaced

\begin{tabular}{|c|c|c|c|c|c|c|c|c|c|}
\hline & $\begin{array}{c}\text { (1) } \\
\text { All } \\
\text { 8-11 }\end{array}$ & $\begin{array}{c}(2) \\
\text { Boys } \\
8-11\end{array}$ & $\begin{array}{c}\text { (3) } \\
\text { Girls } \\
8-11\end{array}$ & $\begin{array}{l}(4) \\
\text { All } \\
8-9\end{array}$ & $\begin{array}{c}(5) \\
\text { Boys } \\
8-9\end{array}$ & $\begin{array}{c}\text { (6) } \\
\text { Girls } \\
8-9\end{array}$ & $\begin{array}{c}\text { (7) } \\
\text { All } \\
10-11\end{array}$ & $\begin{array}{c}\text { (8) } \\
\text { Boys } \\
10-11\end{array}$ & $\begin{array}{c}\text { (9) } \\
\text { Girls } \\
10-11\end{array}$ \\
\hline y2 & $\begin{array}{c}0.071^{\star * \star} \\
(0.017)\end{array}$ & $\begin{array}{c}0.070^{\star \star \star} \\
(0.023)\end{array}$ & $\begin{array}{c}0.072^{\star \star \star} \\
(0.022)\end{array}$ & $\begin{array}{c}0.148^{\star \star \star} \\
(0.024)\end{array}$ & $\begin{array}{c}0.137^{\star * \star} \\
(0.033)\end{array}$ & $\begin{array}{c}0.160^{\star \star \star} \\
(0.034)\end{array}$ & $\begin{array}{c}0.002 \\
(0.018)\end{array}$ & $\begin{array}{c}0.009 \\
(0.025)\end{array}$ & $\begin{array}{l}-0.005 \\
(0.023)\end{array}$ \\
\hline y3 & $\begin{array}{c}0.240 * \star * \\
(0.020)\end{array}$ & $\begin{array}{c}0.240 * \star * \\
(0.023)\end{array}$ & $\begin{array}{c}0.241^{\star \star \star} \\
(0.027)\end{array}$ & $\begin{array}{c}0.345^{\star \star \star} \\
(0.027)\end{array}$ & $\begin{array}{c}0.313^{* * *} \\
(0.034)\end{array}$ & $\begin{array}{c}0.383^{* * *} \\
(0.041)\end{array}$ & $\begin{array}{c}0.147^{\star \star \star} \\
(0.020)\end{array}$ & $\begin{array}{c}0.173^{* \star *} \\
(0.028)\end{array}$ & $\begin{array}{c}0.116^{\star \star *} \\
(0.029)\end{array}$ \\
\hline c1y2 & $\begin{array}{c}-0.184^{\star * *} \\
(0.045)\end{array}$ & $\begin{array}{c}-0.199 * * * * \\
(0.056)\end{array}$ & $\begin{array}{c}-0.172^{\star * *} \\
(0.060)\end{array}$ & $\begin{array}{c}-0.198^{\star * *} \\
(0.047)\end{array}$ & $\begin{array}{c}-0.212^{* * *} \\
(0.065)\end{array}$ & $\begin{array}{c}-0.185^{\star *} \\
(0.074)\end{array}$ & $\begin{array}{c}-0.188^{* * *} \\
(0.061)\end{array}$ & $\begin{array}{c}-0.209 * * \\
(0.088)\end{array}$ & $\begin{array}{c}-0.170^{* *} \\
(0.077)\end{array}$ \\
\hline c1y3 & $\begin{array}{c}-0.127 * * * \\
(0.037)\end{array}$ & $\begin{array}{c}-0.111^{* *} \\
(0.049)\end{array}$ & $\begin{array}{c}-0.141^{* * *} \\
(0.048)\end{array}$ & $\begin{array}{c}-\mathbf{0 . 1 8 2 * * *} \\
(0.053)\end{array}$ & $\begin{array}{l}-0.138^{*} \\
(0.077)\end{array}$ & $\begin{array}{c}-0.233^{* * *} \\
(0.071)\end{array}$ & $\begin{array}{c}-0.089 * * \\
(0.038)\end{array}$ & $\begin{array}{l}-0.106^{*} \\
(0.055)\end{array}$ & $\begin{array}{c}-0.066 \\
(0.055)\end{array}$ \\
\hline $\begin{array}{l}\mathrm{N} \\
\mathrm{r} 2\end{array}$ & $\begin{array}{l}2898 \\
0.151\end{array}$ & $\begin{array}{l}1536 \\
0.155\end{array}$ & $\begin{array}{l}1362 \\
0.146\end{array}$ & $\begin{array}{l}1398 \\
0.217\end{array}$ & $\begin{array}{c}753 \\
0.199\end{array}$ & $\begin{array}{c}645 \\
0.241\end{array}$ & $\begin{array}{l}1500 \\
0.110\end{array}$ & $\begin{array}{c}783 \\
0.130\end{array}$ & $\begin{array}{c}717 \\
0.091\end{array}$ \\
\hline
\end{tabular}

Panel B - House completely damaged

\begin{tabular}{|c|c|c|c|c|c|c|c|c|c|}
\hline & $\begin{array}{c}\text { (1) } \\
\text { All } \\
8-11\end{array}$ & $\begin{array}{c}\text { (2) } \\
\text { Boys } \\
8-11\end{array}$ & $\begin{array}{c}\text { (3) } \\
\text { Girls } \\
\text { 8-11 }\end{array}$ & $\begin{array}{l}\text { (4) } \\
\text { All } \\
8-9\end{array}$ & $\begin{array}{c}\text { (5) } \\
\text { Boys } \\
8-9\end{array}$ & $\begin{array}{c}\text { (6) } \\
\text { Girls } \\
8-9\end{array}$ & $\begin{array}{c}(7) \\
\text { All } \\
10-11\end{array}$ & $\begin{array}{c}(8) \\
\text { Boys } \\
10-11\end{array}$ & $\begin{array}{c}(9) \\
\text { Girls } \\
10-11\end{array}$ \\
\hline$y 2$ & $\begin{array}{c}0.068^{\star \star \star} \\
(0.017)\end{array}$ & $\begin{array}{c}0.071^{\star \star \star} \\
(0.023)\end{array}$ & $\begin{array}{c}0.065^{\star \star \star} \\
(0.021)\end{array}$ & $\begin{array}{c}0.133^{\star \star \star} \\
(0.025)\end{array}$ & $\begin{array}{c}0.137^{\star \star \star} \\
(0.033)\end{array}$ & $\begin{array}{c}0.129^{\star \star \star} \\
(0.031)\end{array}$ & $\begin{array}{c}0.008 \\
(0.018)\end{array}$ & $\begin{array}{c}0.005 \\
(0.025)\end{array}$ & $\begin{array}{c}0.011 \\
(0.024)\end{array}$ \\
\hline y3 & $\begin{array}{c}0.214^{\star * *} \\
(0.019)\end{array}$ & $\begin{array}{c}0.220^{* * *} \\
(0.023)\end{array}$ & $\begin{array}{c}0.206^{\star \star *} \\
(0.027)\end{array}$ & $\begin{array}{c}0.301^{* * *} \\
(0.028)\end{array}$ & $\begin{array}{c}0.284^{* * *} \\
(0.035)\end{array}$ & $\begin{array}{c}0.323^{\star * * *} \\
(0.042)\end{array}$ & $\begin{array}{c}0.133^{\star * *} \\
(0.020)\end{array}$ & $\begin{array}{c}0.157^{* * *} \\
(0.029)\end{array}$ & $\begin{array}{c}0.108 * * * \\
(0.028)\end{array}$ \\
\hline$c 2 y 2$ & $\begin{array}{c}-0.101^{\star *} \\
(0.042)\end{array}$ & $\begin{array}{c}-0.109 * * \\
(0.054)\end{array}$ & $\begin{array}{l}-0.091^{*} \\
(0.054)\end{array}$ & $\begin{array}{l}-0.075 \\
(0.051)\end{array}$ & $\begin{array}{l}-0.137^{*} \\
(0.070)\end{array}$ & $\begin{array}{c}-0.012 \\
(0.070)\end{array}$ & $\begin{array}{c}-0.129 * \star * \\
(0.048)\end{array}$ & $\begin{array}{l}-0.077 \\
(0.067)\end{array}$ & $\begin{array}{c}-0.196 * * * \\
(0.059)\end{array}$ \\
\hline$c 2 y 3$ & $\begin{array}{c}0.027 \\
(0.041)\end{array}$ & $\begin{array}{c}0.016 \\
(0.051)\end{array}$ & $\begin{array}{c}0.040 \\
(0.052)\end{array}$ & $\begin{array}{c}0.046 \\
(0.059)\end{array}$ & $\begin{array}{c}0.027 \\
(0.077)\end{array}$ & $\begin{array}{c}0.061 \\
(0.078)\end{array}$ & $\begin{array}{c}0.004 \\
(0.037)\end{array}$ & $\begin{array}{c}0.014 \\
(0.052)\end{array}$ & $\begin{array}{c}-0.016 \\
(0.056)\end{array}$ \\
\hline $\begin{array}{l}\mathrm{N} \\
\mathrm{r} 2\end{array}$ & $\begin{array}{l}2898 \\
0.147\end{array}$ & $\begin{array}{l}1536 \\
0.153\end{array}$ & $\begin{array}{l}1362 \\
0.142\end{array}$ & $\begin{array}{l}1398 \\
0.209\end{array}$ & $\begin{array}{c}753 \\
0.198\end{array}$ & $\begin{array}{c}645 \\
0.226\end{array}$ & $\begin{array}{l}1500 \\
0.110\end{array}$ & $\begin{array}{c}783 \\
0.122\end{array}$ & $\begin{array}{c}717 \\
0.106\end{array}$ \\
\hline
\end{tabular}

Panel C - Combining the two channel of violence exposure

\begin{tabular}{|c|c|c|c|c|c|c|c|c|c|}
\hline & $\begin{array}{c}\text { (1) } \\
\text { All } \\
\text { 8-11 }\end{array}$ & $\begin{array}{c}(2) \\
\text { Boys } \\
8-11\end{array}$ & $\begin{array}{c}\text { (3) } \\
\text { Girls } \\
8-11\end{array}$ & $\begin{array}{l}\text { (4) } \\
\text { All } \\
8-9\end{array}$ & $\begin{array}{c}\text { (5) } \\
\text { Boys } \\
8-9\end{array}$ & $\begin{array}{c}\text { (6) } \\
\text { Girls } \\
8-9\end{array}$ & $\begin{array}{c}(7) \\
\text { All } \\
10-11\end{array}$ & $\begin{array}{c}(8) \\
\text { Boys } \\
10-11\end{array}$ & $\begin{array}{c}(9) \\
\text { Girls } \\
10-11\end{array}$ \\
\hline y2 & $\begin{array}{c}0.074^{\star \star *} \\
(0.018)\end{array}$ & $\begin{array}{c}0.076^{\star \star \star} \\
(0.024)\end{array}$ & $\begin{array}{c}0.072^{\star \star \star} \\
(0.023)\end{array}$ & $\begin{array}{c}0.142^{\star \star \star} \\
(0.026)\end{array}$ & $\begin{array}{c}0.145^{\star \star *} \\
(0.036)\end{array}$ & $\begin{array}{c}0.138^{\star \star \star} \\
(0.034)\end{array}$ & $\begin{array}{c}0.014 \\
(0.019)\end{array}$ & $\begin{array}{c}0.011 \\
(0.026)\end{array}$ & $\begin{array}{c}0.018 \\
(0.025)\end{array}$ \\
\hline y3 & $\begin{array}{c}0.222^{* * *} \\
(0.021)\end{array}$ & $\begin{array}{c}0.231^{* * *} \\
(0.024)\end{array}$ & $\begin{array}{c}0.212^{\star \star *} \\
(0.030)\end{array}$ & $\begin{array}{c}0.320^{* * *} \\
(0.029)\end{array}$ & $\begin{array}{c}0.306^{\star * *} \\
(0.037)\end{array}$ & $\begin{array}{c}0.338^{\star * *} \\
(0.047)\end{array}$ & $\begin{array}{c}0.136^{\star \star \star *} \\
(0.021)\end{array}$ & $\begin{array}{c}0.159 * * * \\
(0.030)\end{array}$ & $\begin{array}{c}0.110^{* * *} \\
(0.031)\end{array}$ \\
\hline c1y2 & $\begin{array}{c}-0.060 \\
(0.049)\end{array}$ & $\begin{array}{c}-0.076 \\
(0.060)\end{array}$ & $\begin{array}{c}-0.050 \\
(0.062)\end{array}$ & $\begin{array}{c}-0.070 \\
(0.057)\end{array}$ & $\begin{array}{c}-0.086 \\
(0.068)\end{array}$ & $\begin{array}{c}-0.058 \\
(0.087)\end{array}$ & $\begin{array}{c}-0.079 \\
(0.069)\end{array}$ & $\begin{array}{c}-0.122 \\
(0.109)\end{array}$ & $\begin{array}{c}-0.064 \\
(0.085)\end{array}$ \\
\hline c1y3 & $\begin{array}{l}-0.085^{\star} \\
(0.047)\end{array}$ & $\begin{array}{c}-0.154^{* * *} \\
(0.059)\end{array}$ & $\begin{array}{c}-0.041 \\
(0.065)\end{array}$ & $\begin{array}{c}-0.153^{* *} \\
(0.064)\end{array}$ & $\begin{array}{c}-0.248^{* * *} \\
(0.070)\end{array}$ & $\begin{array}{c}-0.098 \\
(0.100)\end{array}$ & $\begin{array}{c}-0.039 \\
(0.055)\end{array}$ & $\begin{array}{c}-0.048 \\
(0.110)\end{array}$ & $\begin{array}{c}-0.020 \\
(0.065)\end{array}$ \\
\hline$c 2 y 2$ & $\begin{array}{l}-0.015 \\
(0.050)\end{array}$ & $\begin{array}{l}-0.030 \\
(0.068)\end{array}$ & $\begin{array}{c}0.002 \\
(0.057)\end{array}$ & $\begin{array}{c}0.027 \\
(0.063)\end{array}$ & $\begin{array}{c}-0.039 \\
(0.091)\end{array}$ & $\begin{array}{c}0.084 \\
(0.077)\end{array}$ & $\begin{array}{c}-0.062 \\
(0.053)\end{array}$ & $\begin{array}{c}-0.011 \\
(0.076)\end{array}$ & $\begin{array}{c}-0.130 \text { ** } \\
(0.058)\end{array}$ \\
\hline $\mathrm{c} 2 \mathrm{y} 3$ & $\begin{array}{c}0.087^{*} \\
(0.050)\end{array}$ & $\begin{array}{c}0.045 \\
(0.064)\end{array}$ & $\begin{array}{l}\mathbf{0 . 1 3 4 * *} \\
(0.058)\end{array}$ & $\begin{array}{c}0.114 \\
(0.072)\end{array}$ & $\begin{array}{c}0.036 \\
(0.096)\end{array}$ & $\begin{array}{l}\mathbf{0 . 1 7 3}^{\star * *} \\
(0.086)\end{array}$ & $\begin{array}{c}0.052 \\
(0.044)\end{array}$ & $\begin{array}{c}0.065 \\
(0.063)\end{array}$ & $\begin{array}{c}0.028 \\
(0.057)\end{array}$ \\
\hline c1c2y2 & $\begin{array}{c}-0.233^{\star *} \\
(0.094)\end{array}$ & $\begin{array}{c}-0.174 \\
(0.114)\end{array}$ & $\begin{array}{c}-0.296^{\star *} \\
(0.123)\end{array}$ & $\begin{array}{c}-0.282^{\star \star * *} \\
(0.104)\end{array}$ & $\begin{array}{l}-0.193 \\
(0.136)\end{array}$ & $\begin{array}{c}-0.364^{\star *} \\
(0.152)\end{array}$ & $\begin{array}{c}-0.156 \\
(0.122)\end{array}$ & $\begin{array}{l}-0.116 \\
(0.171)\end{array}$ & $\begin{array}{l}-0.158 \\
(0.151)\end{array}$ \\
\hline c1c2y3 & $\begin{array}{l}-0.133^{*} \\
(0.077)\end{array}$ & $\begin{array}{c}0.037 \\
(0.103)\end{array}$ & $\begin{array}{c}-\mathbf{0 . 3 0 4} 4^{* * *} \\
(0.087)\end{array}$ & $\begin{array}{l}-0.122 \\
(0.114)\end{array}$ & $\begin{array}{c}0.166 \\
(0.158)\end{array}$ & $\begin{array}{c}-\mathbf{0 . 4 1 3} 3^{\star * *} \\
(0.121)\end{array}$ & $\begin{array}{c}-0.123 \\
(0.075)\end{array}$ & $\begin{array}{c}-0.129 \\
(0.128)\end{array}$ & $\begin{array}{c}-0.119 \\
(0.098)\end{array}$ \\
\hline $\mathrm{N}$ & 2898 & 1536 & 1362 & 1398 & 753 & 645 & 1500 & 783 & 717 \\
\hline r2 & 0.162 & 0.164 & 0.163 & 0.228 & 0.217 & 0.257 & 0.122 & 0.134 & 0.117 \\
\hline
\end{tabular}

Source: Authors' computations using TLSS 2001.

Note: * $p<0.10,{ }^{* \star} p<0.05$, ${ }^{* \star *} p<0.01$; Cluster-Robust standard errors in brackets.

The results show a negative and significant impact of displacement on school attendance in 2001 for the overall sample. The impact on girls is larger than that on boys but the difference is not statistically significant (Panel A, Table 4.1). We observe also that household displacement is associated with more substantial decreases in primary school attendance among younger individuals. This effect is stronger for girls (columns 4-6). Among older individuals, boys seem to be more affected than girls. We do not find any statistically significant effect of house destruction on primary school attendance in 2001 (Panel B, table 4.1), in line with the descriptive analysis in Section 3.2. 
The impact of these two channels of violence exposure becomes clearer once we estimate a triple interaction equation in order to isolate the impact for those that have been only displaced, those with only the house damaged and those affected by both shocks (Panel C, Table 4.1). We find that being affected only by displacement decreases school attendance on average, with stronger effects for boys. Interestingly, exposure to house destruction is associated with increases in school attendance among girls. Individuals affected by both shocks simultaneously reduce their school attendance on average, with girls being more severely affected. All these effects are stronger for younger individuals.

These results suggest that different violence channels affect school attendance in different ways. Displacement is the most disruptive channel in term of consequences on children's school attendance, since all household assets are likely to have been lost (Ibáñez and Moya 2009). The negative impact of displacement on the younger cohort is larger among girls, suggesting that displaced households remove their girls from school, possibly due to fear of their vulnerability to violence (see UNESCO 2011). The negative impact of violence on education among the older cohort of children is stronger for boys than girls. These boys would have been removed from school in order to participate in economic activities within or outside the household (see Table 3.3). It is possible that older boys may have joined the rebellion as fighters. However, the available data does not allow us to test this hypothesis. The negative impact of the conflict on older boys is further emphasized by the negative effect of violence exposure on the increase of grade deficit rates among older boys (Table 4.2, Panel C, column 8).

House destruction would have affected household wealth but perhaps less so if the household was able to keep other assets and live with friends, neighbors or relatives. The impact of the destruction of the house seems also to be associated with improvements in primary school attendance of girls. This may well be because households that experienced the destruction of their house may have joined relatives or friends in urban areas or areas of better access to education infrastructure. Girls may have benefited more from relocation if boys remained behind with their fathers or mothers (perhaps to continuing cultivating the fields or attending to cattle and other assets). These are, however, only speculative remarks since we are not able to test these hypotheses with the available datasets.

Table 4.2 Impact of 1999 violence on grade deficit in 2001 (fixed effect model)

\begin{tabular}{|c|c|c|c|c|c|c|c|c|c|}
\hline & $\begin{array}{c}\text { (1) } \\
\text { All } \\
\text { 8-11 }\end{array}$ & $\begin{array}{c}(2) \\
\text { Boys } \\
8-11\end{array}$ & $\begin{array}{c}\text { (3) } \\
\text { Girls } \\
8-11\end{array}$ & $\begin{array}{l}(4) \\
\text { All } \\
8-9\end{array}$ & $\begin{array}{c}(5) \\
\text { Boys } \\
8-9\end{array}$ & $\begin{array}{c}(6) \\
\text { Girls } \\
8-9\end{array}$ & $\begin{array}{c}(7) \\
\text { All } \\
10-11\end{array}$ & $\begin{array}{c}(8) \\
\text { Boys } \\
10-11\end{array}$ & $\begin{array}{c}\text { (9) } \\
\text { Girls } \\
10-11\end{array}$ \\
\hline y2 & $\begin{array}{c}0.211^{\star \star \star} \\
(0.029)\end{array}$ & $\begin{array}{c}0.195^{\star \star \star} \\
(0.037)\end{array}$ & $\begin{array}{c}0.228^{\star \star \star} \\
(0.038)\end{array}$ & $\begin{array}{c}0.238^{\star \star \star} \\
(0.040)\end{array}$ & $\begin{array}{c}0.231^{\star \star \star} \\
(0.053)\end{array}$ & $\begin{array}{c}0.247^{\star \star \star} \\
(0.062)\end{array}$ & $\begin{array}{c}0.194^{\star \star \star} \\
(0.035)\end{array}$ & $\begin{array}{c}0.173^{\star \star \star} \\
(0.046)\end{array}$ & $\begin{array}{c}0.217^{\star \star \star} \\
(0.046)\end{array}$ \\
\hline y3 & $\begin{array}{c}0.388^{\star * * *} \\
(0.039)\end{array}$ & $\begin{array}{c}0.369 * * * \\
(0.047)\end{array}$ & $\begin{array}{c}0.409 * \star * \\
(0.050)\end{array}$ & $\begin{array}{c}0.458 * * * \\
(0.055)\end{array}$ & $\begin{array}{c}0.440 * \star * \\
(0.071)\end{array}$ & $\begin{array}{c}0.481^{\star * *} \\
(0.075)\end{array}$ & $\begin{array}{c}0.347^{\star * *} \\
(0.044)\end{array}$ & $\begin{array}{c}0.327^{\star \star *} \\
(0.056)\end{array}$ & $\begin{array}{c}0.370^{\star * *} \\
(0.058)\end{array}$ \\
\hline c1y2 & $\begin{array}{l}-0.037 \\
(0.062)\end{array}$ & $\begin{array}{c}0.042 \\
(0.086)\end{array}$ & $\begin{array}{c}-0.098 \\
(0.072)\end{array}$ & $\begin{array}{l}-0.108^{\star} \\
(0.062)\end{array}$ & $\begin{array}{l}-0.040 \\
(0.102)\end{array}$ & $\begin{array}{c}-0.167^{\star *} \\
(0.077)\end{array}$ & $\begin{array}{c}0.023 \\
(0.089)\end{array}$ & $\begin{array}{c}0.121 \\
(0.138)\end{array}$ & $\begin{array}{l}-0.045 \\
(0.102)\end{array}$ \\
\hline c1y3 & $\begin{array}{l}-0.051 \\
(0.080)\end{array}$ & $\begin{array}{l}-0.054 \\
(0.097)\end{array}$ & $\begin{array}{l}-0.057 \\
(0.112)\end{array}$ & $\begin{array}{l}-0.132 \\
(0.115)\end{array}$ & $\begin{array}{l}-0.201 \\
(0.144)\end{array}$ & $\begin{array}{l}-0.081 \\
(0.177)\end{array}$ & $\begin{array}{c}0.001 \\
(0.092)\end{array}$ & $\begin{array}{c}0.085 \\
(0.129)\end{array}$ & $\begin{array}{l}-0.059 \\
(0.125)\end{array}$ \\
\hline $\mathrm{N}$ & 1644 & 837 & 807 & 642 & 336 & 306 & 1002 & 501 & 501 \\
\hline r2 & 0.195 & 0.193 & 0.200 & 0.234 & 0.237 & 0.242 & 0.173 & 0.170 & 0.178 \\
\hline
\end{tabular}


Panel B - House completely damaged

\begin{tabular}{|c|c|c|c|c|c|c|c|c|c|}
\hline & $\begin{array}{c}\text { (1) } \\
\text { All } \\
\text { 8-11 }\end{array}$ & $\begin{array}{c}(2) \\
\text { Boys } \\
8-11\end{array}$ & $\begin{array}{c}\text { (3) } \\
\text { Girls } \\
8-11\end{array}$ & $\begin{array}{l}\text { (4) } \\
\text { All } \\
8-9\end{array}$ & $\begin{array}{c}(5) \\
\text { Boys } \\
8-9\end{array}$ & $\begin{array}{c}\text { (6) } \\
\text { Girls } \\
8-9\end{array}$ & $\begin{array}{c}\text { (7) } \\
\text { All } \\
10-11\end{array}$ & $\begin{array}{c}\text { (8) } \\
\text { Boys } \\
10-11\end{array}$ & $\begin{array}{c}\text { (9) } \\
\text { Girls } \\
10-11\end{array}$ \\
\hline$y 2$ & $\begin{array}{c}0.207^{\star \star \star} \\
(0.031)\end{array}$ & $\begin{array}{c}0.213^{\star \star \star} \\
(0.040)\end{array}$ & $\begin{array}{c}0.200^{\star \star \star} \\
(0.038)\end{array}$ & $\begin{array}{c}0.202^{\star \star \star} \\
(0.039)\end{array}$ & $\begin{array}{c}0.211^{\star \star \star} \\
(0.052)\end{array}$ & $\begin{array}{c}0.192^{\star \star \star} \\
(0.059)\end{array}$ & $\begin{array}{c}0.209 * \star \star \\
(0.038)\end{array}$ & $\begin{array}{c}0.214^{\star \star \star} \\
(0.049)\end{array}$ & $\begin{array}{c}0.205^{\star \star \star} \\
(0.048)\end{array}$ \\
\hline y3 & $\begin{array}{c}0.359 * \star * \\
(0.040)\end{array}$ & $\begin{array}{c}0.343^{* * *} \\
(0.048)\end{array}$ & $\begin{array}{c}0.376^{\star \star \star} \\
(0.052)\end{array}$ & $\begin{array}{c}0.399 * \star * \\
(0.053)\end{array}$ & $\begin{array}{c}0.356 * \star * \\
(0.068)\end{array}$ & $\begin{array}{c}0.449 * * * \\
(0.078)\end{array}$ & $\begin{array}{c}0.333^{\star * *} \\
(0.047)\end{array}$ & $\begin{array}{c}0.333^{\star \star *} \\
(0.063)\end{array}$ & $\begin{array}{c}0.333^{* * *} \\
(0.060)\end{array}$ \\
\hline $\mathrm{c} 2 \mathrm{y} 2$ & $\begin{array}{c}-0.010 \\
(0.056)\end{array}$ & $\begin{array}{c}-0.054 \\
(0.075)\end{array}$ & $\begin{array}{c}0.037 \\
(0.081)\end{array}$ & $\begin{array}{c}0.058 \\
(0.072)\end{array}$ & $\begin{array}{c}0.062 \\
(0.115)\end{array}$ & $\begin{array}{c}0.058 \\
(0.109)\end{array}$ & $\begin{array}{c}-0.051 \\
(0.076)\end{array}$ & $\begin{array}{l}-0.117 \\
(0.096)\end{array}$ & $\begin{array}{c}0.024 \\
(0.102)\end{array}$ \\
\hline c2y3 & $\begin{array}{c}0.092 \\
(0.073)\end{array}$ & $\begin{array}{c}0.086 \\
(0.091)\end{array}$ & $\begin{array}{c}0.098 \\
(0.106)\end{array}$ & $\begin{array}{c}0.145 \\
(0.119)\end{array}$ & $\begin{array}{c}0.235 \\
(0.180)\end{array}$ & $\begin{array}{c}0.051 \\
(0.171)\end{array}$ & $\begin{array}{c}0.061 \\
(0.088)\end{array}$ & $\begin{array}{c}0.008 \\
(0.107)\end{array}$ & $\begin{array}{c}0.124 \\
(0.123)\end{array}$ \\
\hline $\begin{array}{l}\mathrm{N} \\
\mathrm{r} 2\end{array}$ & $\begin{array}{l}1644 \\
0.197\end{array}$ & $\begin{array}{c}837 \\
0.196\end{array}$ & $\begin{array}{c}807 \\
0.201\end{array}$ & $\begin{array}{c}642 \\
0.234\end{array}$ & $\begin{array}{c}336 \\
0.240\end{array}$ & $\begin{array}{c}306 \\
0.237\end{array}$ & $\begin{array}{l}1002 \\
0.176\end{array}$ & $\begin{array}{c}501 \\
0.174\end{array}$ & $\begin{array}{c}501 \\
0.181\end{array}$ \\
\hline
\end{tabular}

Panel C - Combining the two channel of violence exposure

\begin{tabular}{|c|c|c|c|c|c|c|c|c|c|}
\hline & $\begin{array}{c}\text { (1) } \\
\text { All } \\
8-11\end{array}$ & $\begin{array}{c}(2) \\
\text { Boys } \\
8-11\end{array}$ & $\begin{array}{c}\text { (3) } \\
\text { Girls } \\
8-11 \\
\end{array}$ & $\begin{array}{l}\text { (4) } \\
\text { All } \\
8-9\end{array}$ & $\begin{array}{c}\text { (5) } \\
\text { Boys } \\
8-9\end{array}$ & $\begin{array}{c}\text { (6) } \\
\text { Girls } \\
8-9\end{array}$ & $\begin{array}{c}\text { (7) } \\
\text { All } \\
10-11 \\
\end{array}$ & $\begin{array}{c}\text { (8) } \\
\text { Boys } \\
10-11 \\
\end{array}$ & $\begin{array}{c}\text { (9) } \\
\text { Girls } \\
10-11\end{array}$ \\
\hline$y 2$ & $\begin{array}{c}0.222^{\star \star \star} \\
(0.034)\end{array}$ & $\begin{array}{c}0.216^{\star \star \star} \\
(0.042)\end{array}$ & $\begin{array}{c}0.227^{\star \star \star} \\
(0.042)\end{array}$ & $\begin{array}{c}0.221^{\star \star \star} \\
(0.045)\end{array}$ & $\begin{array}{c}0.203^{\star \star \star} \\
(0.059)\end{array}$ & $\begin{array}{c}0.242^{\star \star \star} \\
(0.070)\end{array}$ & $\begin{array}{c}0.222^{\star \star \star} \\
(0.040)\end{array}$ & $\begin{array}{c}0.225^{\star \star \star} \\
(0.052)\end{array}$ & $\begin{array}{c}0.219^{* \star \star} \\
(0.053)\end{array}$ \\
\hline y3 & $\begin{array}{c}0.370 * \star \star \\
(0.042)\end{array}$ & $\begin{array}{c}0.356^{\star \star \star} \\
(0.051)\end{array}$ & $\begin{array}{c}0.386^{\star \star \star} \\
(0.055)\end{array}$ & $\begin{array}{c}0.404^{\star * *} \\
(0.057)\end{array}$ & $\begin{array}{c}0.365^{\star \star *} \\
(0.074)\end{array}$ & $\begin{array}{c}0.452^{\star \star \star} \\
(0.082)\end{array}$ & $\begin{array}{c}0.350 * * * \\
(0.050)\end{array}$ & $\begin{array}{c}0.350^{\star * *} \\
(0.065)\end{array}$ & $\begin{array}{c}0.351^{* * *} \\
(0.065)\end{array}$ \\
\hline c1y2 & $\begin{array}{c}-0.114^{*} \\
(0.061)\end{array}$ & $\begin{array}{l}-0.035 \\
(0.092)\end{array}$ & $\begin{array}{c}-0.168 * \star * \\
(0.057)\end{array}$ & $\begin{array}{l}-0.096 \\
(0.075)\end{array}$ & $\begin{array}{c}0.047 \\
(0.126)\end{array}$ & $\begin{array}{c}-0.242^{\star \star \star} \\
(0.070)\end{array}$ & $\begin{array}{c}-0.139 * * \\
(0.065)\end{array}$ & $\begin{array}{c}-0.225^{\star * *} \\
(0.052)\end{array}$ & $\begin{array}{c}-0.108 \\
(0.090)\end{array}$ \\
\hline c1y3 & $\begin{array}{l}-0.085 \\
(0.105)\end{array}$ & $\begin{array}{c}-0.128 \\
(0.140)\end{array}$ & $\begin{array}{c}-0.063 \\
(0.128)\end{array}$ & $\begin{array}{c}-0.029 \\
(0.148)\end{array}$ & $\begin{array}{c}-0.052 \\
(0.187)\end{array}$ & $\begin{array}{c}-0.014 \\
(0.219)\end{array}$ & $\begin{array}{l}-0.184^{*} \\
(0.104)\end{array}$ & $\begin{array}{c}-0.350 * * * \\
(0.065)\end{array}$ & $\begin{array}{c}-0.129 \\
(0.137)\end{array}$ \\
\hline c2y2 & $\begin{array}{l}-0.059 \\
(0.053)\end{array}$ & $\begin{array}{c}-0.110 \\
(0.082)\end{array}$ & $\begin{array}{c}0.003 \\
(0.078)\end{array}$ & $\begin{array}{c}0.092 \\
(0.089)\end{array}$ & $\begin{array}{c}0.150 \\
(0.135)\end{array}$ & $\begin{array}{c}0.025 \\
(0.139)\end{array}$ & $\begin{array}{c}-0.148^{\star \star} \\
(0.069)\end{array}$ & $\begin{array}{c}-0.258^{\star * *} \\
(0.089)\end{array}$ & $\begin{array}{c}-0.011 \\
(0.095)\end{array}$ \\
\hline c2y3 & $\begin{array}{c}0.095 \\
(0.084)\end{array}$ & $\begin{array}{c}0.070 \\
(0.112)\end{array}$ & $\begin{array}{c}0.126 \\
(0.109)\end{array}$ & $\begin{array}{l}0.283^{* *} \\
(0.137)\end{array}$ & $\begin{array}{l}0.400^{\star} \\
(0.205)\end{array}$ & $\begin{array}{c}0.148 \\
(0.190)\end{array}$ & $\begin{array}{l}-0.017 \\
(0.103)\end{array}$ & $\begin{array}{l}-0.117 \\
(0.127)\end{array}$ & $\begin{array}{c}0.107 \\
(0.135)\end{array}$ \\
\hline c1c2y2 & $\begin{array}{c}0.229 \\
(0.141)\end{array}$ & $\begin{array}{c}0.241 \\
(0.187)\end{array}$ & $\begin{array}{c}0.188 \\
(0.178)\end{array}$ & $\begin{array}{c}-0.074 \\
(0.154)\end{array}$ & $\begin{array}{c}-0.400 \text { ** } \\
(0.169)\end{array}$ & $\begin{array}{c}0.197 \\
(0.216)\end{array}$ & $\begin{array}{l}0.428^{\star *} \\
(0.173)\end{array}$ & $\begin{array}{c}0.713^{\star \star \star} \\
(0.196)\end{array}$ & $\begin{array}{c}0.173 \\
(0.234)\end{array}$ \\
\hline c1c2y3 & $\begin{array}{c}0.036 \\
(0.194) \\
\end{array}$ & $\begin{array}{c}0.140 \\
(0.221) \\
\end{array}$ & $\begin{array}{c}-0.050 \\
(0.264) \\
\end{array}$ & $\begin{array}{c}-0.444^{*} \\
(0.264)\end{array}$ & $\begin{array}{c}-0.712^{\star *} \\
(0.274)\end{array}$ & $\begin{array}{c}-0.253 \\
(0.375) \\
\end{array}$ & $\begin{array}{l}0.396 * * \\
(0.190)\end{array}$ & 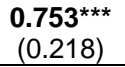 & $\begin{array}{c}0.125 \\
(0.272) \\
\end{array}$ \\
\hline $\begin{array}{l}\mathrm{N} \\
\mathrm{r} 2\end{array}$ & $\begin{array}{l}1644 \\
0.201\end{array}$ & $\begin{array}{c}837 \\
0.201\end{array}$ & $\begin{array}{c}807 \\
0.206\end{array}$ & $\begin{array}{c}642 \\
0.249\end{array}$ & $\begin{array}{c}336 \\
0.270\end{array}$ & $\begin{array}{c}306 \\
0.252\end{array}$ & $\begin{array}{l}1002 \\
0.185\end{array}$ & $\begin{array}{c}501 \\
0.200\end{array}$ & $\begin{array}{c}501 \\
0.184\end{array}$ \\
\hline
\end{tabular}

Source: Authors' computations using TLSS 2001

Note: * $p<0.10,{ }^{\star *} p<0.05,{ }^{\star *} p<0.01$; Cluster-Robust standard errors in brackets.

\subsection{School completion in 2007}

Table 4.3 reports the estimates of our analysis of the effect of the 1999 violence on primary school completion in 2007 over the sample of individuals born between 1977 and 1992. Column 1 shows the estimated results for the whole sample.

Table 4.3 Effect of 1999 violence on primary school completion in 2007, Sample 1977-1992

\begin{tabular}{|c|c|c|c|c|c|c|}
\hline & $\begin{array}{c}\text { (1) } \\
\text { All } \\
\text { b/se }\end{array}$ & $\begin{array}{c}(2) \\
\text { Boys } \\
\text { b/se }\end{array}$ & $\begin{array}{c}\text { (3) } \\
\text { Girls } \\
\text { b/se }\end{array}$ & $\begin{array}{c}\text { (4) } \\
\text { All } \\
\text { b/se }\end{array}$ & $\begin{array}{c}\text { (5) } \\
\text { Boys } \\
\text { b/se }\end{array}$ & $\begin{array}{l}\text { (6) } \\
\text { Girls } \\
\text { b/se }\end{array}$ \\
\hline Exp in prim school & $\begin{array}{l}-0.041 \\
(0.029)\end{array}$ & $\begin{array}{c}-0.183^{\star \star *} \\
(0.044)\end{array}$ & $\begin{array}{l}0.104^{\star \star} \\
(0.047)\end{array}$ & & & \\
\hline Exp in grade 1-3 & & & & $\begin{array}{l}-0.069 * \\
(0.038)\end{array}$ & $\begin{array}{c}-0.210^{\star * *} \\
(0.056)\end{array}$ & $\begin{array}{c}0.080 \\
(0.064)\end{array}$ \\
\hline Exp in grade 4-6 & & & & $\begin{array}{l}-0.040 \\
(0.029)\end{array}$ & $\begin{array}{c}-0.183^{* * *} \\
(0.044)\end{array}$ & $\begin{array}{l}0.105^{* *} \\
(0.048)\end{array}$ \\
\hline Year fe & Yes & Yes & Yes & Yes & Yes & Yes \\
\hline District fe & Yes & Yes & Yes & Yes & Yes & Yes \\
\hline District trend & Yes & Yes & Yes & Yes & Yes & Yes \\
\hline Controls & Yes & Yes & Yes & Yes & Yes & Yes \\
\hline $\mathrm{N}$ & 6676 & 3383 & 3293 & 6676 & 3383 & 3293 \\
\hline
\end{tabular}

Source: Authors' computations using TLSS 2007

Note: ${ }^{*} p<0.10,{ }^{* \star} p<0.05,{ }^{* \star \star} p<0.01$; Cluster-Robust standard errors in brackets. Sample: $1977-1992$.

The coefficient for the violence measure is negative but not statistically significant. However, once we split the sample between boys and girls (columns 2 and 3), we find that being 
exposed to the violence in one of the years in which children were supposed to have attended primary school affects negatively the probability of primary school completion of boys and positively the probability of primary school completion among girls. The results show that boys exposed to the violence during their primary school years are 18 percentage points less likely to have completed primary school several years after the violence. On the contrary, we observe that girls exposed to the violence are 10 percentage points more likely to complete primary school in 2007 . These results are in line with the descriptive evidence discussed in Section 3, and with some of the results obtained for 2001: boys seem to have been more negatively affected by the conflict in Timor Leste than girls. We have also disaggregated the results across age groups in order to examine whether being exposed to violence at the start of the primary school (first three grades) or later (last three grades) makes a difference in terms of primary school completion. Columns 4-6 in Table 4.3 show that the coefficients are particularly strong for younger and older boys (the coefficient is slightly higher for younger boys) and for older girls.

We now turn to the effect of peaks of violence in the earlier years of the conflict on primary school completion observed in 2007. Table 4.4 shows the results over the sample of individuals born between 1968 and 1984. Our variable of interest is still defined as a dummy which identifies whether the individuals were exposed or not to the conflict. As before, the effects are negative for boys and positive for girls, although the coefficients are not statistically significant. We find, however, a statistically significant negative effect of violence on boys attending the last three grades of primary school.

Table 4.4 Effect of early years of conflict on primary school completion in 2007, Sample 1968-1984

\begin{tabular}{|c|c|c|c|c|c|c|}
\hline & $\begin{array}{c}\text { (1) } \\
\text { All } \\
\text { b/se }\end{array}$ & $\begin{array}{c}\text { (2) } \\
\text { Boys } \\
\text { b/se }\end{array}$ & $\begin{array}{c}\text { (3) } \\
\text { Girls } \\
\text { b/se }\end{array}$ & $\begin{array}{c}\text { (4) } \\
\text { All } \\
\text { b/se }\end{array}$ & $\begin{array}{c}\text { (5) } \\
\text { Boys } \\
\text { b/se }\end{array}$ & $\begin{array}{l}\text { (6) } \\
\text { Girls } \\
\text { b/se }\end{array}$ \\
\hline Exp in prim school & $\begin{array}{c}-0.012 \\
(0.024)\end{array}$ & $\begin{array}{l}-0.035 \\
(0.031)\end{array}$ & $\begin{array}{c}0.020 \\
(0.038)\end{array}$ & & & \\
\hline Exp in grade 1-3 & & & & $\begin{array}{c}-0.017 \\
(0.018)\end{array}$ & $\begin{array}{c}-0.031 \\
(0.023)\end{array}$ & $\begin{array}{c}0.006 \\
(0.031)\end{array}$ \\
\hline Exp in grade 4-6 & & & & $\begin{array}{c}-0.041 \\
(0.027)\end{array}$ & $\begin{array}{c}-0.065^{*} \\
(0.034)\end{array}$ & $\begin{array}{c}-0.017 \\
(0.040)\end{array}$ \\
\hline Year fe & Yes & Yes & Yes & Yes & Yes & Yes \\
\hline District fe & Yes & Yes & Yes & Yes & Yes & Yes \\
\hline District trend & Yes & Yes & Yes & Yes & Yes & Yes \\
\hline Controls & Yes & Yes & Yes & Yes & Yes & Yes \\
\hline $\mathrm{N}$ & 5195 & 2625 & 2570 & 5195 & 2625 & 2570 \\
\hline
\end{tabular}

Source: Authors' computations using TLSS 2007

Note: ${ }^{*} p<0.10,{ }^{*} p<0.05,{ }^{* \star *} p<0.01$; Cluster-Robust standard errors in brackets. Sample: $1968-1984$.

In Table 4.5, we repeat the estimations reported in Table 4.4 but use a continuous variable to measure exposure to violence. As discussed in Section 3 , this is because during the earlier stages of the conflict, individuals could have been affected by violence for more than one year. Our variable of interest now is defined as the number of years of exposure to the conflict during primary school (ranging from 0 to 6 ). This measure not only tells us whether being exposed to the conflict affects primary school completion, but also informs us on the effect of an additional year of exposure to violence. Column 1-3 in Table 4.5 show the results of the re-estimated model. We find that an additional year of exposure on primary school completion in 2007 decreases school completion for all individuals. However, the negative effect is statistically significant only for boys (column 2). Again we find that exposure to violence has a particularly negative impact on school completion of boys, particularly those attending the last three years of primary school (grades 4 to 6) (column 5). We do not find a significant effect for girls. 
Table 4.5 Effect of early years of conflict on primary school completion in 2007, Sample 1968-1984

\begin{tabular}{|c|c|c|c|c|c|c|}
\hline & $\begin{array}{c}\text { (1) } \\
\text { All } \\
\text { b/se }\end{array}$ & $\begin{array}{c}\text { (2) } \\
\text { Boys } \\
\text { b/se }\end{array}$ & $\begin{array}{c}\text { (3) } \\
\text { Girls } \\
\text { b/se }\end{array}$ & $\begin{array}{c}\text { (4) } \\
\text { All } \\
\text { b/se }\end{array}$ & $\begin{array}{l}(5) \\
\text { Boys } \\
\text { b/se }\end{array}$ & $\begin{array}{l}(6) \\
\text { Girls } \\
\text { b/se }\end{array}$ \\
\hline $\begin{array}{l}\text { N Ys Exp in prim } \\
\text { school }\end{array}$ & $\begin{array}{l}-0.026^{\star \star} \\
(0.011)\end{array}$ & $\begin{array}{l}-0.030 \star \star \\
(0.014)\end{array}$ & $\begin{array}{l}-0.021 \\
(0.017)\end{array}$ & & & \\
\hline $\begin{array}{l}N \text { Ys Exp in grade } \\
1-3\end{array}$ & & & & $\begin{array}{l}-0.021 * \\
(0.012)\end{array}$ & $\begin{array}{l}-0.022 \\
(0.016)\end{array}$ & $\begin{array}{l}-0.018 \\
(0.020)\end{array}$ \\
\hline $\begin{array}{l}\text { N Ys Exp in grade } \\
4-6\end{array}$ & & & & $\begin{array}{l}-0.040^{* *} \\
(0.018)\end{array}$ & $\begin{array}{l}-0.054^{\star *} \\
(0.021)\end{array}$ & $\begin{array}{l}-0.031 \\
(0.028)\end{array}$ \\
\hline Year fe & Yes & Yes & Yes & Yes & Yes & Yes \\
\hline District fe & Yes & Yes & Yes & Yes & Yes & Yes \\
\hline District trend & Yes & Yes & Yes & Yes & Yes & Yes \\
\hline Controls & Yes & Yes & Yes & Yes & Yes & Yes \\
\hline $\mathrm{N}$ & 5195 & 2625 & 2570 & 5195 & 2625 & 2570 \\
\hline
\end{tabular}

Source: Authors' computations using TLSS 2007

Note: ${ }^{*} p<0.10,{ }^{\star \star} p<0.05,{ }^{* \star *} p<0.01$; Cluster-Robust standard errors in brackets. Sample: 1968-1984.

Finally, Table 4.6 reports the estimates for the effect of the whole conflict on primary school completion in 2007. The sample includes individuals born between 1968 and 1992 . The results show the average effect of exposure to both the first years of the conflict and the 1999 violence. Since we are looking at both periods of violence, we only look at the effect of being exposed or not during primary school years in order not to confound the results. ${ }^{26}$ The results show that boys exposed to the conflict in any period are 7.4 percentage points less likely to complete primary school. The effect on girls is positive but both the size and the significance are quite small. We find once more that the overall conflict has a strong and negative effect on primary school completion among boys attending the last three years of primary school.

Table 4.6 Effect of entire conflict on primary school completion in 2007, Sample 19681992

\begin{tabular}{|c|c|c|c|c|c|c|}
\hline & $\begin{array}{l}\text { (1) } \\
\text { All }\end{array}$ & $\begin{array}{c}\text { (2) } \\
\text { Boys }\end{array}$ & $\begin{array}{c}\text { (3) } \\
\text { Girls }\end{array}$ & $\begin{array}{l}\text { (4) } \\
\text { All }\end{array}$ & $\begin{array}{c}\text { (5) } \\
\text { Boys }\end{array}$ & $\begin{array}{c}(6) \\
\text { Girls }\end{array}$ \\
\hline Exp in prim school & $\begin{array}{c}-0.012 \\
(0.020)\end{array}$ & $\begin{array}{c}-0.074^{\star \star \star} \\
(0.027)\end{array}$ & $\begin{array}{l}0.055^{\star} \\
(0.030)\end{array}$ & & & \\
\hline Exp in grade 1-3 & & & & $\begin{array}{l}-0.006 \\
(0.019)\end{array}$ & $\begin{array}{l}-0.035 \\
(0.023)\end{array}$ & $\begin{array}{c}0.031 \\
(0.029)\end{array}$ \\
\hline Exp in grade 4-6 & & & & $\begin{array}{l}-0.019 \\
(0.019)\end{array}$ & $\begin{array}{c}-0.075^{\star \star \star} \\
(0.027)\end{array}$ & $\begin{array}{c}0.044 \\
(0.029)\end{array}$ \\
\hline Year fe & Yes & Yes & Yes & Yes & Yes & Yes \\
\hline District fe & Yes & Yes & Yes & Yes & Yes & Yes \\
\hline District trend & Yes & Yes & Yes & Yes & Yes & Yes \\
\hline Controls & Yes & Yes & Yes & Yes & Yes & Yes \\
\hline $\mathrm{N}$ & 9329 & 4753 & 4576 & 9329 & 4753 & 4576 \\
\hline
\end{tabular}

Source: Authors' computations using TLSS 2007.

Note: ${ }^{*} p<0.10,{ }^{* *} p<0.05,{ }^{* * \star} p<0.01$; Cluster-Robust standard errors in brackets. Sample: $1968-1992$.

The results indicate that the 1999 wave of violence, peaks of violence in the earlier stages of the conflict and the overall conflict have had very different effects on boys and girls and on younger and older children. Girls in general do not seem to have been severely affected by the conflict in Timor Leste and show even small educational improvements following the 1999 events. This result would suggest that while girls have been negatively hit by exposure to the early years of the conflict when their attendance was still very low, they seem to have recovered over the years and their catching up process does not seem to have been hindered by the 1999 violence. The net effect of the whole conflict on girls in areas of violence is not different from the effect on girls that were not exposed to violence. 
Boys have been negatively affected by the conflict in Timor Leste at all stages. We find a negative effect of the conflict on primary school completion among both younger and older boys following the 1999 violence, and among older boys following the earlier peaks of violence and across the whole conflict duration. Table 3.3 suggests that boys affected by violence in Timor Leste tend to work more and for longer hours. This is in line with findings in the literature on household coping strategies in face of adverse shocks. The use of children as a form of economic security mechanism is widely reported in the development economics literature (see Dasgupta 1993; Nugent and Gillaspy 1983), as is the resort to child labor as a form of compensating for low-incomes (e.g. Duryea, Lam and Levinson 2007). Children that are needed to replace labor are removed from school. In areas of violent conflict, households may decide to replace dead, injured, absent or disabled adult workers with children (if these have not become fighters as well). Akresh and de Walque (2009), Merrouche (2006), Shemyakina (2006) and Swee (2009) put forward this mechanism as a possible explanation for the reduction in education attainment and enrolment observed in contexts of civil war. In a recent paper, Rodriguez and Sanchez (2009) test directly the effect of war of child labor and find that violent attacks in Colombian municipalities by armed groups have increased significantly the probability of school drop-out and increased the inclusion of children in the labor market. These effects may have intergenerational consequences as their children are likely to also remain trapped in a cycle of low human capital and low productivity. In the case of Timor Leste, these effects may also have considerable consequences for the country's future economic and political stability. Recent episodes of civil violence - including the civil strife in 2006 - have been linked to high levels of unemployment and lack of skills among young males (Muggah et al. 2010; Scambary 2006). This may well have resulted from lost education opportunities among boys during the 25 years of conflict, although we would need data beyond 2007 to test this hypothesis in more detail.

\subsection{Robustness checks}

We have performed several robustness checks in order to address some important issues that may affect our estimates above. The main issues we address are the possible exposure of the sample surveyed in 2007 to the civil violence that erupted in Timor Leste in 2006, and impending selection biases in the 2001 and 2007 results due to non-random migration patterns.

\subsubsection{Civil war exposure in 2006}

One important concern with the results discussed in the previous section is whether some estimates may be capturing the civil violence that took place in Dili during the implementation of the TLSS 2007 (see Section 3). In 2006, Timor Leste experienced large internal civil strife as a result of fighting between different factions in the independence forces. The violence in 2006 resulted in 37 killings, 2,000 severely damaged houses, 3,000 completely destroyed houses, and 150,000 displaced people (against 400,000 in 1999) (Muggah et al. 2010; Scambary 2006). Most displaced people were located around Dili (65 IDP camps were put in place), and were still displaced in 2007. These events took place at the time of the implementation of the TLSS 2007 in March 2006. In order to minimize exposure to the violence, and due to the security situation, the TLSS 2007 was interrupted and resumed in January 2007. All households interviewed previously were re-interviewed. It is, however, still possible that some biases may remain. In particular, it is possible that some of the results we obtain are not due to exposure to the 1999 violence but to exposure to the civil upheaval in 2006.

In order to control for this potential exposure to the violence in 2006, we explore a variable in the 2007 dataset that captures whether an individual has been absent from home in the past 12 months for security reasons. ${ }^{27}$ Our calculations show that individuals who have been 
absent from home for security reasons in 2006 are all residing in Dili. Therefore, we believe that this dummy reliably captures quite well the level of exposure to the 2006 violence.

Table 4.7 (see over) shows these results. The coefficients are almost identical to those in Tables 4.3, 4.4 and 4.5 and therefore we do not have any reason to believe that the results discussed in Section 4.2 are biased by the effects of the civil violence in 2006.

Table 4.7 Robustness check. Effect of conflict on primary school completion in 2007, controlling for 2007 civil violence

\begin{tabular}{|c|c|c|c|c|c|c|}
\hline & \multicolumn{3}{|c|}{ Sample1977-1992 } & \multicolumn{3}{|c|}{ Sample1968-1984 } \\
\hline & (1) & $(2)$ & (3) & (4) & (5) & $(6)$ \\
\hline & All & Boys & Girls & All & Boys & Girls \\
\hline \multirow[t]{2}{*}{ Exp in prim school } & -0.042 & $-0.186^{\star \star \star}$ & $0.105^{\star \star}$ & -0.012 & -0.037 & 0.021 \\
\hline & $(0.029)$ & $(0.044)$ & $(0.047)$ & $(0.024)$ & $(0.031)$ & $(0.038)$ \\
\hline \multirow[t]{2}{*}{ N Ys Exp in prim school } & & & & $-0.026^{\star *}$ & $-0.032^{\star *}$ & -0.021 \\
\hline & & & & $(0.011)$ & $(0.014)$ & $(0.017)$ \\
\hline \multirow[t]{2}{*}{ Absent home past 12 months } & $0.083^{\star \star \star}$ & 0.066 & $0.104^{\star \star \star}$ & $0.085^{\star * *}$ & $0.092^{\star *}$ & $0.080 *$ \\
\hline & $(0.023)$ & $(0.043)$ & $(0.032)$ & $(0.030)$ & $(0.040)$ & $(0.045)$ \\
\hline Year fe & Yes & Yes & Yes & Yes & Yes & Yes \\
\hline District fe & Yes & Yes & Yes & Yes & Yes & Yes \\
\hline District trend & Yes & Yes & Yes & Yes & Yes & Yes \\
\hline Controls & Yes & Yes & Yes & Yes & Yes & Yes \\
\hline $\mathrm{N}$ & 6676 & 3383 & 3293 & 5195 & 2625 & 2570 \\
\hline
\end{tabular}

Note: ${ }^{*} p<0.10,{ }^{\star \star} p<0.05,{ }^{* \star \star} p<0.01$; Cluster-Robust standard errors in brackets.

\subsubsection{Migration biases in the analysis of school outcomes in 2001 and 2007}

A final important concern in our analysis is the fact that some individuals have migrated at some point in their lives, thereby introducing a potential selection bias in the results. The 2001 and 2007 datasets provide information on their place of birth and their place of current residence. ${ }^{28}$ If both coincide, then we can infer that they either did not migrate or migrated but only temporarily. There is, however, a group of individuals that migrated to a different place from the place of birth. The percentage of those that migrated represents 13 per cent of the sample in 2001, and 19 per cent and 24 per cent respectively in the two samples of 2007..$^{29}$

The data does not allow us to establish when this migration occurred, or whether these individuals migrated for conflict related reasons. But a form of selectivity bias may occur if individuals did not choose the new place of residence randomly (the so called 'spatial sorting', see Kondylis 2010). For instance, if we find that those that migrated went to areas in which economic conditions are typically better (for instance, urban areas), our results would be likely to exhibit a downward bias in the effect of violence on education.

We have estimated the impact of a potential spatial sorting effect in tables 4.8 and 4.9 (for 2001) and table 4.10 (for 2007). These tables (see over, pages 42-3) show the estimated results for the sample of individuals that never moved from the place of birth to the place of current residence for 2001 and 2007, respectively. These calculations test if the results in Section 4.1 and 4.2 hold if we restrict the sample to those that did not move. The hypothesis we test is the following: if the coefficient on violence for those that did not migrate is similar to the one that we get when estimating the whole sample, then we can be quite confident in the validity of our results and argue that migration does not affect our estimates. 
Calculations using the 2001 sample show that children that do not move have slightly lower attendance rates than the entire sample (71.1 per cent versus 72.1 per cent, respectively). This difference is not statistically significant. As a result, the coefficients obtained on the nonmigrant sample (Tables 4.8 and 4.9) do not differ from the results shown in Tables 3.6 and 3.7. We are able therefore to infer with confidence that our results are not driven by spatial sorting biases in the 2001 dataset.

Table 4.10 (page 44) shows the impact of violence on school attainment in 2007 for the sample of non-migrant individuals. The coefficients in columns 1-3 do not significantly differ from estimates in Table 4.3. Our results of the effects of the 1999 violence on school completion in 2007 do not seem therefore to be driven by a process of spatial sorting (i.e. are not driven by those that migrated). Columns 4-6 of Table 4.10 show slightly weaker results than those in table 4.4 and 4.5 , but the main coefficients do not change substantially.

Table 4.8 Robustness check. Impact of 1999 violence on school attendance in 2001, controlling for migration

Panel A - Displaced

\begin{tabular}{|c|c|c|c|c|c|c|c|c|c|}
\hline & $\begin{array}{c}\text { (1) } \\
\text { All } \\
\text { 8-11 } \\
\end{array}$ & $\begin{array}{c}\text { (2) } \\
\text { Boys } \\
8-11 \\
\end{array}$ & $\begin{array}{c}\text { (3) } \\
\text { Girls } \\
\text { 8-11 }\end{array}$ & $\begin{array}{l}\text { (4) } \\
\text { All } \\
8-9 \\
\end{array}$ & $\begin{array}{c}\text { (5) } \\
\text { Boys } \\
8-9 \\
\end{array}$ & $\begin{array}{c}\text { (6) } \\
\text { Girls } \\
8-9 \\
\end{array}$ & $\begin{array}{c}\text { (7) } \\
\text { All } \\
10-11 \\
\end{array}$ & $\begin{array}{c}\text { (8) } \\
\text { Boys } \\
10-11 \\
\end{array}$ & $\begin{array}{c}\text { (9) } \\
\text { Girls } \\
10-11 \\
\end{array}$ \\
\hline y2 & $\begin{array}{c}0.065^{\star \star \star} \\
(0.018)\end{array}$ & $\begin{array}{c}0.065^{\star \star \star} \\
(0.025)\end{array}$ & $\begin{array}{c}0.065^{\star \star \star} \\
(0.024)\end{array}$ & $\begin{array}{c}0.140 * \star \star \\
(0.026)\end{array}$ & $\begin{array}{c}0.133^{\star \star \star} \\
(0.034)\end{array}$ & $\begin{array}{c}0.148^{\star \star \star} \\
(0.036)\end{array}$ & $\begin{array}{l}-0.005 \\
(0.020)\end{array}$ & $\begin{array}{l}-0.000 \\
(0.028)\end{array}$ & $\begin{array}{c}-0.012 \\
(0.027)\end{array}$ \\
\hline y3 & $\begin{array}{c}0.247^{\star * *} \\
(0.021)\end{array}$ & $\begin{array}{c}0.245^{\star \star *} \\
(0.024)\end{array}$ & $\begin{array}{c}0.249 * * * \\
(0.029)\end{array}$ & $\begin{array}{c}0.348^{\star * *} \\
(0.028)\end{array}$ & $\begin{array}{c}0.316^{\star \star \star} \\
(0.036)\end{array}$ & $\begin{array}{c}0.387^{\star \star \star} \\
(0.044)\end{array}$ & $\begin{array}{c}0.152^{\star \star \star} \\
(0.021)\end{array}$ & $\begin{array}{c}0.176^{\star \star \star} \\
(0.029)\end{array}$ & $\begin{array}{c}0.124^{\star \star \star} \\
(0.032)\end{array}$ \\
\hline c1y2 & $\begin{array}{c}-0.200^{* * *} \\
(0.052)\end{array}$ & $\begin{array}{c}-0.213^{\star \star \star *} \\
(0.063)\end{array}$ & $\begin{array}{c}-0.188^{\star *} \\
(0.072)\end{array}$ & $\begin{array}{c}-0.199 * \star \star * \\
(0.054)\end{array}$ & $\begin{array}{c}-0.218^{\star \star \star} \\
(0.072)\end{array}$ & $\begin{array}{c}-0.180 * * \\
(0.090)\end{array}$ & $\begin{array}{c}-0.215^{\star \star \star \star} \\
(0.072)\end{array}$ & $\begin{array}{c}-0.231^{\star *} \\
(0.099)\end{array}$ & $\begin{array}{c}-0.200^{* *} \\
(0.093)\end{array}$ \\
\hline c1y3 & $\begin{array}{c}-0.144^{* * *} \\
(0.038)\end{array}$ & $\begin{array}{c}-0.130 * * * \\
(0.050)\end{array}$ & $\begin{array}{c}-0.157^{\star * *} \\
(0.053)\end{array}$ & $\begin{array}{c}-0.198 * * * \\
(0.054)\end{array}$ & $\begin{array}{c}-0.173^{\star *} \\
(0.080)\end{array}$ & $\begin{array}{c}-0.231^{\star * *} \\
(0.078)\end{array}$ & $\begin{array}{c}-0.102^{\star *} \\
(0.042)\end{array}$ & $\begin{array}{l}-0.100 \\
(0.061)\end{array}$ & $\begin{array}{l}-0.093 \\
(0.060) \\
\end{array}$ \\
\hline $\mathrm{N}$ & 2553 & 1383 & 1170 & 1254 & 693 & 561 & 1299 & 690 & 609 \\
\hline r2 & 0.157 & 0.161 & 0.154 & 0.217 & 0.198 & 0.243 & 0.124 & 0.144 & 0.104 \\
\hline
\end{tabular}

Source: Authors' computations using TLSS 2001.

Note: * $p<0.10,{ }^{* *} p<0.05,{ }^{* * *} p<0.01$; Cluster-Robust standard errors in brackets.

Panel B - House completely damaged

\begin{tabular}{|c|c|c|c|c|c|c|c|c|c|}
\hline & $\begin{array}{c}\text { (1) } \\
\text { All } \\
\text { 8-11 }\end{array}$ & $\begin{array}{c}(2) \\
\text { Boys } \\
8-11 \\
\end{array}$ & $\begin{array}{c}\text { (3) } \\
\text { Girls } \\
\text { 8-11 }\end{array}$ & $\begin{array}{l}\text { (4) } \\
\text { All } \\
8-9 \\
\end{array}$ & $\begin{array}{c}\text { (5) } \\
\text { Boys } \\
8-9 \\
\end{array}$ & $\begin{array}{c}\text { (6) } \\
\text { Girls } \\
8-9\end{array}$ & $\begin{array}{c}\text { (7) } \\
\text { All } \\
\text { 10-11 }\end{array}$ & $\begin{array}{c}\text { (8) } \\
\text { Boys } \\
10-11\end{array}$ & $\begin{array}{c}\text { (9) } \\
\text { Girls } \\
10-11\end{array}$ \\
\hline$y 2$ & $\begin{array}{c}0.065^{\star \star \star} \\
(0.018)\end{array}$ & $\begin{array}{c}0.066^{\star \star \star} \\
(0.024)\end{array}$ & $\begin{array}{c}0.064^{\star \star \star} \\
(0.023)\end{array}$ & $\begin{array}{c}0.129 \star \star \star \\
(0.025)\end{array}$ & $\begin{array}{c}0.129^{\star \star \star} \\
(0.034)\end{array}$ & $\begin{array}{c}0.129^{\star * \star} \\
(0.034)\end{array}$ & $\begin{array}{c}0.003 \\
(0.020)\end{array}$ & $\begin{array}{c}-0.000 \\
(0.028)\end{array}$ & $\begin{array}{c}0.006 \\
(0.028)\end{array}$ \\
\hline y3 & $\begin{array}{c}0.224^{\star \star \star} \\
(0.020)\end{array}$ & $\begin{array}{c}0.227^{\star \star \star} \\
(0.024)\end{array}$ & $\begin{array}{c}0.221^{\star * *} \\
(0.029)\end{array}$ & $\begin{array}{c}0.303^{\star \star \star} \\
(0.028)\end{array}$ & $\begin{array}{c}0.281^{\star \star *} \\
(0.036)\end{array}$ & $\begin{array}{c}0.331^{\star * *} \\
(0.044)\end{array}$ & $\begin{array}{c}0.149 * \star \star \\
(0.021)\end{array}$ & $\begin{array}{c}0.171^{\star * *} \\
(0.030)\end{array}$ & $\begin{array}{c}0.126 * \star * \\
(0.031)\end{array}$ \\
\hline c2y2 & $\begin{array}{c}-0.124^{\star \star \star} \\
(0.047)\end{array}$ & $\begin{array}{c}-0.119^{*} \\
(0.061)\end{array}$ & $\begin{array}{c}-0.129 \star * \\
(0.062)\end{array}$ & $\begin{array}{c}-0.090 \\
(0.057)\end{array}$ & $\begin{array}{c}-0.129 \\
(0.079)\end{array}$ & $\begin{array}{c}-0.046 \\
(0.081)\end{array}$ & $\begin{array}{c}-0.157^{\star \star \star} \\
(0.055)\end{array}$ & $\begin{array}{l}-0.100 \\
(0.074)\end{array}$ & $\begin{array}{c}-0.234^{\star \star \star} \\
(0.070)\end{array}$ \\
\hline c2y3 & $\begin{array}{c}0.005 \\
(0.044)\end{array}$ & $\begin{array}{c}0.003 \\
(0.054)\end{array}$ & $\begin{array}{c}0.007 \\
(0.056)\end{array}$ & $\begin{array}{c}0.054 \\
(0.065)\end{array}$ & $\begin{array}{c}0.040 \\
(0.084)\end{array}$ & $\begin{array}{c}0.065 \\
(0.086)\end{array}$ & $\begin{array}{l}-0.043 \\
(0.038)\end{array}$ & $\begin{array}{c}-0.021 \\
(0.055)\end{array}$ & $\begin{array}{l}-0.080^{*} \\
(0.048)\end{array}$ \\
\hline $\begin{array}{l}\mathrm{N} \\
\mathrm{r} 2\end{array}$ & $\begin{array}{l}2553 \\
0.154\end{array}$ & $\begin{array}{l}1383 \\
0.157\end{array}$ & $\begin{array}{l}1170 \\
0.150\end{array}$ & $\begin{array}{l}1254 \\
0.211\end{array}$ & $\begin{array}{c}693 \\
0.195\end{array}$ & $\begin{array}{c}561 \\
0.232\end{array}$ & $\begin{array}{l}1299 \\
0.122\end{array}$ & $\begin{array}{c}690 \\
0.134\end{array}$ & $\begin{array}{c}609 \\
0.119\end{array}$ \\
\hline
\end{tabular}

Source: Authors' computations using TLSS 2001

Note: * $p<0.10$, ${ }^{\star \star} p<0.05$, ${ }^{\star \star \star} p<0.01$; Cluster-Robust standard errors in brackets. 
Panel C - Combining the two channel of violence exposure

\begin{tabular}{|c|c|c|c|c|c|c|c|c|c|}
\hline & $\begin{array}{c}\text { (1) } \\
\text { All } \\
8-11\end{array}$ & $\begin{array}{c}\text { (2) } \\
\text { Boys } \\
8-11\end{array}$ & $\begin{array}{c}\text { (3) } \\
\text { Girls } \\
8-11\end{array}$ & $\begin{array}{l}(4) \\
\text { All } \\
8-9\end{array}$ & $\begin{array}{c}\text { (5) } \\
\text { Boys } \\
8-9\end{array}$ & $\begin{array}{c}\text { (6) } \\
\text { Girls } \\
8-9\end{array}$ & $\begin{array}{c}(7) \\
\text { All } \\
10-11\end{array}$ & $\begin{array}{c}(8) \\
\text { Boys } \\
10-11\end{array}$ & $\begin{array}{c}(9) \\
\text { Girls } \\
10-11\end{array}$ \\
\hline y2 & $\begin{array}{c}0.070^{\star \star \star} \\
(0.019)\end{array}$ & $\begin{array}{c}0.071^{* * *} \\
(0.025)\end{array}$ & $\begin{array}{c}0.069 * * * \\
(0.025)\end{array}$ & $\begin{array}{c}0.135^{\star \star *} \\
(0.027)\end{array}$ & $\begin{array}{c}0.136^{\star \star \star} \\
(0.037)\end{array}$ & $\begin{array}{c}0.133^{\star * *} \\
(0.035)\end{array}$ & $\begin{array}{c}0.010 \\
(0.021)\end{array}$ & $\begin{array}{c}0.006 \\
(0.028)\end{array}$ & $\begin{array}{c}0.014 \\
(0.029)\end{array}$ \\
\hline y3 & $\begin{array}{c}0.232 * \star * \\
(0.022)\end{array}$ & $\begin{array}{c}0.237^{\star \star *} \\
(0.026)\end{array}$ & $\begin{array}{c}0.226 * * * \\
(0.032)\end{array}$ & $\begin{array}{c}0.319 * * * \\
(0.030)\end{array}$ & $\begin{array}{c}0.302^{\star \star *} \\
(0.039)\end{array}$ & $\begin{array}{c}0.342^{\star * \star} \\
(0.048)\end{array}$ & $\begin{array}{c}0.151^{\star \star \star} \\
(0.023)\end{array}$ & $\begin{array}{c}0.172^{* \star *} \\
(0.031)\end{array}$ & $\begin{array}{c}0.128^{\star \star *} \\
(0.034)\end{array}$ \\
\hline c1y2 & $\begin{array}{l}-0.053 \\
(0.058)\end{array}$ & $\begin{array}{c}-0.071 \\
(0.067)\end{array}$ & $\begin{array}{c}-0.042 \\
(0.076)\end{array}$ & $\begin{array}{l}-0.049 \\
(0.067)\end{array}$ & $\begin{array}{l}-0.073 \\
(0.072)\end{array}$ & $\begin{array}{l}-0.028 \\
(0.110)\end{array}$ & $\begin{array}{l}-0.090 \\
(0.085)\end{array}$ & $\begin{array}{l}-0.149 \\
(0.136)\end{array}$ & $\begin{array}{l}-0.070 \\
(0.104)\end{array}$ \\
\hline c1y3 & $\begin{array}{l}-0.082 \\
(0.053)\end{array}$ & $\begin{array}{c}-0.150 * * \\
(0.066)\end{array}$ & $\begin{array}{l}-0.037 \\
(0.074)\end{array}$ & $\begin{array}{l}-0.148^{\star *} \\
(0.070)\end{array}$ & $\begin{array}{c}-0.240^{* * *} \\
(0.074)\end{array}$ & $\begin{array}{l}-0.079 \\
(0.114)\end{array}$ & $\begin{array}{l}-0.031 \\
(0.065)\end{array}$ & $\begin{array}{l}-0.029 \\
(0.137)\end{array}$ & $\begin{array}{l}-0.017 \\
(0.075)\end{array}$ \\
\hline $\mathrm{c} 2 \mathrm{y} 2$ & $\begin{array}{l}-0.027 \\
(0.057)\end{array}$ & $\begin{array}{l}-0.031 \\
(0.077)\end{array}$ & $\begin{array}{l}-0.022 \\
(0.067)\end{array}$ & $\begin{array}{c}0.025 \\
(0.072)\end{array}$ & $\begin{array}{l}-0.018 \\
(0.100)\end{array}$ & $\begin{array}{c}0.067 \\
(0.089)\end{array}$ & $\begin{array}{l}-0.081 \\
(0.061)\end{array}$ & $\begin{array}{l}-0.031 \\
(0.086)\end{array}$ & $\begin{array}{c}-0.152^{* *} \\
(0.069)\end{array}$ \\
\hline c2y3 & $\begin{array}{c}0.077 \\
(0.055)\end{array}$ & $\begin{array}{c}0.043 \\
(0.070)\end{array}$ & $\begin{array}{l}0.118^{*} \\
(0.065)\end{array}$ & $\begin{array}{c}0.145^{\star} \\
(0.079)\end{array}$ & $\begin{array}{c}0.080 \\
(0.104)\end{array}$ & $\begin{array}{l}0.201^{* *} \\
(0.096)\end{array}$ & $\begin{array}{c}0.006 \\
(0.047)\end{array}$ & $\begin{array}{c}0.023 \\
(0.069)\end{array}$ & $\begin{array}{l}-0.024 \\
(0.057)\end{array}$ \\
\hline c1c2y2 & $\begin{array}{c}-0.263^{\star *} \\
(0.108)\end{array}$ & $\begin{array}{l}-0.206 \\
(0.129)\end{array}$ & $\begin{array}{c}-0.326 * * \\
(0.143)\end{array}$ & $\begin{array}{c}-0.329 * \star \star \\
(0.120)\end{array}$ & $\begin{array}{l}-0.255^{\star} \\
(0.153)\end{array}$ & $\begin{array}{c}-0.403^{\star \star} \\
(0.177)\end{array}$ & $\begin{array}{l}-0.162 \\
(0.141)\end{array}$ & $\begin{array}{l}-0.090 \\
(0.199)\end{array}$ & $\begin{array}{l}-0.192 \\
(0.179)\end{array}$ \\
\hline c1c2y3 & $\begin{array}{l}-0.167^{*} \\
(0.088)\end{array}$ & $\begin{array}{c}0.002 \\
(0.113)\end{array}$ & $\begin{array}{c}-0.343^{* * *} \\
(0.096)\end{array}$ & $\begin{array}{l}-0.191 \\
(0.126)\end{array}$ & $\begin{array}{c}0.068 \\
(0.169)\end{array}$ & $\begin{array}{c}-0.464^{* * *} \\
(0.136)\end{array}$ & $\begin{array}{l}-0.126 \\
(0.088)\end{array}$ & $\begin{array}{l}-0.114 \\
(0.159)\end{array}$ & $\begin{array}{l}-0.154 \\
(0.107)\end{array}$ \\
\hline $\mathrm{N}$ & 2553 & 1383 & 1170 & 1254 & 693 & 561 & 1299 & 690 & 609 \\
\hline r2 & 0.169 & 0.169 & 0.173 & 0.232 & 0.215 & 0.263 & 0.135 & 0.146 & 0.132 \\
\hline
\end{tabular}

Source: Authors' computations using TLSS 2001

Note: ${ }^{*} p<0.10,{ }^{* \star} p<0.05,{ }^{* \star \star} p<0.01$; Cluster-Robust standard errors in brackets.

Table 4.9 Robustness check. Impact of 1999 violence on grade deficit in 2001, controlling for migration

Panel A - Displaced

\begin{tabular}{|c|c|c|c|c|c|c|c|c|c|}
\hline & $\begin{array}{c}\text { (1) } \\
\text { All } \\
\text { 8-11 }\end{array}$ & $\begin{array}{c}(2) \\
\text { Boys } \\
8-11\end{array}$ & $\begin{array}{c}\text { (3) } \\
\text { Girls } \\
8-11\end{array}$ & $\begin{array}{l}(4) \\
\text { All } \\
8-9\end{array}$ & $\begin{array}{c}(5) \\
\text { Boys } \\
8-9\end{array}$ & $\begin{array}{c}\text { (6) } \\
\text { Girls } \\
8-9\end{array}$ & $\begin{array}{c}(7) \\
\text { All } \\
10-11\end{array}$ & $\begin{array}{c}(8) \\
\text { Boys } \\
10-11\end{array}$ & $\begin{array}{c}\text { (9) } \\
\text { Girls } \\
10-11\end{array}$ \\
\hline $\mathrm{y} 2$ & $\begin{array}{c}0.234^{\star \star \star} \\
(0.031)\end{array}$ & $\begin{array}{c}0.215^{\star \star \star} \\
(0.041)\end{array}$ & $\begin{array}{c}0.256^{\star \star \star} \\
(0.040)\end{array}$ & $\begin{array}{c}0.264^{\star \star \star} \\
(0.043)\end{array}$ & $\begin{array}{c}0.253^{\star \star \star} \\
(0.058)\end{array}$ & $\begin{array}{c}0.277^{\star \star \star} \\
(0.067)\end{array}$ & $\begin{array}{c}0.215^{\star \star \star} \\
(0.037)\end{array}$ & $\begin{array}{c}0.191^{* \star *} \\
(0.051)\end{array}$ & $\begin{array}{c}0.243^{\star \star \star} \\
(0.047)\end{array}$ \\
\hline y3 & $\begin{array}{c}0.414^{\star \star *} \\
(0.043)\end{array}$ & $\begin{array}{c}0.393^{\star * *} \\
(0.052)\end{array}$ & $\begin{array}{c}0.439 * \star * \\
(0.054)\end{array}$ & $\begin{array}{c}0.473^{\star \star *} \\
(0.060)\end{array}$ & $\begin{array}{c}0.446 * \star \star \\
(0.076)\end{array}$ & $\begin{array}{c}0.508^{\star \star \star *} \\
(0.087)\end{array}$ & $\begin{array}{c}0.378^{\star * *} \\
(0.048)\end{array}$ & $\begin{array}{c}0.359 * \star * \\
(0.063)\end{array}$ & $\begin{array}{c}0.400^{\star * *} \\
(0.059)\end{array}$ \\
\hline c1y2 & $\begin{array}{l}-0.007 \\
(0.071)\end{array}$ & $\begin{array}{c}0.058 \\
(0.097)\end{array}$ & $\begin{array}{c}-0.065 \\
(0.084)\end{array}$ & $\begin{array}{c}-0.110 \\
(0.070)\end{array}$ & $\begin{array}{c}-0.053 \\
(0.107)\end{array}$ & $\begin{array}{l}-0.172^{*} \\
(0.093)\end{array}$ & $\begin{array}{c}0.090 \\
(0.101)\end{array}$ & $\begin{array}{c}0.194 \\
(0.163)\end{array}$ & $\begin{array}{c}0.017 \\
(0.113)\end{array}$ \\
\hline c1y3 & $\begin{array}{c}-0.014 \\
(0.094)\end{array}$ & $\begin{array}{c}-0.029 \\
(0.109)\end{array}$ & $\begin{array}{c}-0.010 \\
(0.139)\end{array}$ & $\begin{array}{c}-0.114 \\
(0.131)\end{array}$ & $\begin{array}{c}-0.196 \\
(0.152)\end{array}$ & $\begin{array}{c}-0.034 \\
(0.221)\end{array}$ & $\begin{array}{c}0.066 \\
(0.109)\end{array}$ & $\begin{array}{c}0.180 \\
(0.142)\end{array}$ & $\begin{array}{c}-0.009 \\
(0.149)\end{array}$ \\
\hline $\begin{array}{l}\mathrm{N} \\
\mathrm{r} 2\end{array}$ & $\begin{array}{l}1407 \\
0.219\end{array}$ & $\begin{array}{c}741 \\
0.208\end{array}$ & $\begin{array}{c}666 \\
0.234\end{array}$ & $\begin{array}{c}561 \\
0.244\end{array}$ & $\begin{array}{c}309 \\
0.237\end{array}$ & $\begin{array}{c}252 \\
0.264\end{array}$ & $\begin{array}{c}846 \\
0.207\end{array}$ & $\begin{array}{c}432 \\
0.198\end{array}$ & $\begin{array}{c}414 \\
0.220\end{array}$ \\
\hline
\end{tabular}

Source: Authors' computations using TLSS 2001

Note: * $p<0.10,{ }^{* \star} p<0.05$, ${ }^{* \star} p<0.01$; Cluster-Robust standard errors in brackets.

Panel B - House completely damaged

\begin{tabular}{|c|c|c|c|c|c|c|c|c|c|}
\hline & $\begin{array}{c}\text { (1) } \\
\text { All } \\
\text { 8-11 } \\
\end{array}$ & $\begin{array}{c}(2) \\
\text { Boys } \\
8-11 \\
\end{array}$ & $\begin{array}{c}\mathbf{( 3 )} \\
\text { Girls } \\
\mathbf{8 - 1 1} \\
\end{array}$ & $\begin{array}{l}\text { (4) } \\
\text { All } \\
8-9\end{array}$ & $\begin{array}{c}\text { (5) } \\
\text { Boys } \\
8-9 \\
\end{array}$ & $\begin{array}{c}\text { (6) } \\
\text { Girls } \\
8-9\end{array}$ & $\begin{array}{c}\text { (7) } \\
\text { All } \\
\text { 10-11 }\end{array}$ & $\begin{array}{c}\text { (8) } \\
\text { Boys } \\
10-11 \\
\end{array}$ & $\begin{array}{c}\text { (9) } \\
\text { Girls } \\
10-11\end{array}$ \\
\hline$y 2$ & $\begin{array}{c}0.236^{\star \star \star} \\
(0.033)\end{array}$ & $\begin{array}{c}0.234^{\star \star \star} \\
(0.044)\end{array}$ & $\begin{array}{c}0.239 \star \star \star \\
(0.039)\end{array}$ & $\begin{array}{c}0.228^{\star \star \star} \\
(0.041)\end{array}$ & $\begin{array}{c}0.232^{\star \star \star} \\
(0.057)\end{array}$ & $\begin{array}{c}0.224^{\star \star \star} \\
(0.062)\end{array}$ & $\begin{array}{c}0.242^{\star \star \star} \\
(0.039)\end{array}$ & $\begin{array}{c}0.236^{\star \star \star} \\
(0.054)\end{array}$ & $\begin{array}{c}0.248^{\star \star \star} \\
(0.048)\end{array}$ \\
\hline y3 & $\begin{array}{c}0.394^{\star * *} \\
(0.043)\end{array}$ & $\begin{array}{c}0.365^{\star * *} \\
(0.053)\end{array}$ & $\begin{array}{c}0.426^{\star * *} \\
(0.056)\end{array}$ & $\begin{array}{c}0.416^{* \star *} \\
(0.058)\end{array}$ & $\begin{array}{c}0.366^{* * *} \\
(0.073)\end{array}$ & $\begin{array}{c}0.478^{* * *} \\
(0.089)\end{array}$ & $\begin{array}{c}0.379 * * * \\
(0.051)\end{array}$ & $\begin{array}{c}0.364^{\star * *} \\
(0.070)\end{array}$ & $\begin{array}{c}0.394^{* * *} \\
(0.062)\end{array}$ \\
\hline c2y2 & $\begin{array}{c}-0.019 \\
(0.061)\end{array}$ & $\begin{array}{c}-0.053 \\
(0.084)\end{array}$ & $\begin{array}{c}0.022 \\
(0.089)\end{array}$ & $\begin{array}{c}0.061 \\
(0.079)\end{array}$ & $\begin{array}{c}0.054 \\
(0.121)\end{array}$ & $\begin{array}{c}0.070 \\
(0.128)\end{array}$ & $\begin{array}{l}-0.067 \\
(0.084)\end{array}$ & $\begin{array}{c}-0.119 \\
(0.112)\end{array}$ & $\begin{array}{c}-0.006 \\
(0.106)\end{array}$ \\
\hline c2y3 & $\begin{array}{c}0.081 \\
(0.078)\end{array}$ & $\begin{array}{c}0.108 \\
(0.101)\end{array}$ & $\begin{array}{c}0.052 \\
(0.120) \\
\end{array}$ & $\begin{array}{c}0.163 \\
(0.134) \\
\end{array}$ & $\begin{array}{c}0.206 \\
(0.188) \\
\end{array}$ & $\begin{array}{c}0.111 \\
(0.223)\end{array}$ & $\begin{array}{c}0.034 \\
(0.096)\end{array}$ & $\begin{array}{c}0.048 \\
(0.121) \\
\end{array}$ & $\begin{array}{c}0.019 \\
(0.128) \\
\end{array}$ \\
\hline $\begin{array}{l}\mathrm{N} \\
\mathrm{r} 2\end{array}$ & $\begin{array}{l}1407 \\
0.222\end{array}$ & $\begin{array}{c}741 \\
0.214\end{array}$ & $\begin{array}{c}666 \\
0.234\end{array}$ & $\begin{array}{c}561 \\
0.245\end{array}$ & $\begin{array}{c}309 \\
0.238\end{array}$ & $\begin{array}{c}252 \\
0.260\end{array}$ & $\begin{array}{c}846 \\
0.208\end{array}$ & $\begin{array}{c}432 \\
0.200\end{array}$ & $\begin{array}{c}414 \\
0.221\end{array}$ \\
\hline
\end{tabular}

Source: Authors' computations using TLSS 2001

Note: * $p<0.10,{ }^{* \star} p<0.05$, ${ }^{* \star} p<0.01$; Cluster-Robust standard errors in brackets. 
Panel C - Combining the two channel of violence exposure

\begin{tabular}{|c|c|c|c|c|c|c|c|c|c|}
\hline & $\begin{array}{c}\text { (1) } \\
\text { All } \\
8-11\end{array}$ & $\begin{array}{c}(2) \\
\text { Boys } \\
8-11\end{array}$ & $\begin{array}{c}\text { (3) } \\
\text { Girls } \\
8-11\end{array}$ & $\begin{array}{l}(4) \\
\text { All } \\
8-9\end{array}$ & $\begin{array}{c}\text { (5) } \\
\text { Boys } \\
8-9\end{array}$ & $\begin{array}{c}(6) \\
\text { Girls } \\
8-9\end{array}$ & $\begin{array}{c}(7) \\
\text { All } \\
10-11\end{array}$ & $\begin{array}{c}\text { (8) } \\
\text { Boys } \\
10-11\end{array}$ & $\begin{array}{c}(9) \\
\text { Girls } \\
10-11\end{array}$ \\
\hline y2 & $\begin{array}{c}0.250 \star \star \star \\
(0.035)\end{array}$ & $\begin{array}{c}0.237^{\star \star \star} \\
(0.046)\end{array}$ & $\begin{array}{c}0.265^{\star \star \star} \\
(0.044)\end{array}$ & $\begin{array}{c}0.244^{\star \star \star} \\
(0.047)\end{array}$ & $\begin{array}{c}0.224^{\star \star *} \\
(0.065)\end{array}$ & $\begin{array}{c}0.268^{\star \star \star} \\
(0.072)\end{array}$ & $\begin{array}{c}0.254^{\star \star \star} \\
(0.041)\end{array}$ & $\begin{array}{c}0.245^{\star \star \star} \\
(0.056)\end{array}$ & $\begin{array}{c}0.263^{\star \star *} \\
(0.053)\end{array}$ \\
\hline y3 & $\begin{array}{c}0.401^{\star \star \star} \\
(0.046)\end{array}$ & $\begin{array}{c}0.376^{\star * *} \\
(0.057)\end{array}$ & $\begin{array}{c}0.430^{\star \star \star} \\
(0.059)\end{array}$ & $\begin{array}{c}0.415^{\star \star \star} \\
(0.062)\end{array}$ & $\begin{array}{c}0.373^{\star * *} \\
(0.080)\end{array}$ & $\begin{array}{c}0.464^{\star \star *} \\
(0.091)\end{array}$ & $\begin{array}{c}0.393^{\star \star \star} \\
(0.054)\end{array}$ & $\begin{array}{c}0.377^{\star * *} \\
(0.072)\end{array}$ & $\begin{array}{c}0.411^{\star * *} \\
(0.068)\end{array}$ \\
\hline c1y2 & $\begin{array}{l}-0.114 \\
(0.074)\end{array}$ & $\begin{array}{c}-0.026 \\
(0.105)\end{array}$ & $\begin{array}{c}-0.185^{\star *} \\
(0.071)\end{array}$ & $\begin{array}{c}-0.090 \\
(0.088)\end{array}$ & $\begin{array}{c}0.043 \\
(0.133)\end{array}$ & $\begin{array}{c}-0.268^{\star \star * *} \\
(0.072)\end{array}$ & $\begin{array}{l}-0.143^{*} \\
(0.081)\end{array}$ & $\begin{array}{c}-0.245^{\star \star *} \\
(0.056)\end{array}$ & $\begin{array}{c}-0.120 \\
(0.111)\end{array}$ \\
\hline c1y3 & $\begin{array}{l}-0.060 \\
(0.130)\end{array}$ & $\begin{array}{l}-0.113 \\
(0.161)\end{array}$ & $\begin{array}{l}-0.030 \\
(0.168)\end{array}$ & $\begin{array}{c}0.008 \\
(0.175)\end{array}$ & $\begin{array}{l}-0.040 \\
(0.200)\end{array}$ & $\begin{array}{c}0.081 \\
(0.297)\end{array}$ & $\begin{array}{l}-0.171 \\
(0.132)\end{array}$ & $\begin{array}{c}-0.377^{\star * *} \\
(0.072)\end{array}$ & $\begin{array}{l}-0.125 \\
(0.170)\end{array}$ \\
\hline$c 2 y 2$ & $\begin{array}{l}-0.093 \\
(0.057)\end{array}$ & $\begin{array}{l}-0.115 \\
(0.092)\end{array}$ & $\begin{array}{c}-0.058 \\
(0.084)\end{array}$ & $\begin{array}{c}0.116 \\
(0.097)\end{array}$ & $\begin{array}{c}0.151 \\
(0.144)\end{array}$ & $\begin{array}{c}0.065 \\
(0.173)\end{array}$ & $\begin{array}{c}-0.209^{\star * *} \\
(0.074)\end{array}$ & $\begin{array}{c}-0.285^{\star \star *} \\
(0.103)\end{array}$ & $\begin{array}{c}-0.113 \\
(0.093)\end{array}$ \\
\hline c2y3 & $\begin{array}{c}0.070 \\
(0.090)\end{array}$ & $\begin{array}{c}0.088 \\
(0.124)\end{array}$ & $\begin{array}{c}0.052 \\
(0.123)\end{array}$ & $\begin{array}{l}0.345^{\star \star} \\
(0.159)\end{array}$ & $\begin{array}{l}0.377^{\star} \\
(0.218)\end{array}$ & $\begin{array}{c}0.313 \\
(0.279)\end{array}$ & $\begin{array}{l}-0.082 \\
(0.109)\end{array}$ & $\begin{array}{l}-0.097 \\
(0.147)\end{array}$ & $\begin{array}{l}-0.061 \\
(0.126)\end{array}$ \\
\hline c1c2y2 & $\begin{array}{l}0.311^{* *} \\
(0.156)\end{array}$ & $\begin{array}{c}0.262 \\
(0.209)\end{array}$ & $\begin{array}{l}0.331^{\star} \\
(0.186)\end{array}$ & $\begin{array}{l}-0.116 \\
(0.169)\end{array}$ & $\begin{array}{c}-0.418^{\star *} \\
(0.178)\end{array}$ & $\begin{array}{c}0.185 \\
(0.248)\end{array}$ & $\begin{array}{c}0.598^{\star \star \star} \\
(0.177)\end{array}$ & $\begin{array}{c}0.841^{\star * *} \\
(0.204)\end{array}$ & $\begin{array}{c}0.415^{\star} \\
(0.221)\end{array}$ \\
\hline c1c2y3 & $\begin{array}{c}0.073 \\
(0.224)\end{array}$ & $\begin{array}{c}0.149 \\
(0.244)\end{array}$ & $\begin{array}{c}0.018 \\
(0.312)\end{array}$ & $\begin{array}{l}-0.538^{*} \\
(0.300)\end{array}$ & $\begin{array}{c}-0.710 * * \\
(0.291)\end{array}$ & $\begin{array}{l}-0.484 \\
(0.477)\end{array}$ & $\begin{array}{l}0.526 * * \\
(0.216)\end{array}$ & $\begin{array}{c}0.875^{\star \star \star} \\
(0.219)\end{array}$ & $\begin{array}{c}0.330 \\
(0.306)\end{array}$ \\
\hline $\begin{array}{l}\mathrm{N} \\
\mathrm{r} 2\end{array}$ & $\begin{array}{l}1407 \\
0.226\end{array}$ & $\begin{array}{c}741 \\
0.219\end{array}$ & $\begin{array}{c}666 \\
0.240\end{array}$ & $\begin{array}{c}561 \\
0.263\end{array}$ & $\begin{array}{c}309 \\
0.267\end{array}$ & $\begin{array}{c}252 \\
0.285\end{array}$ & $\begin{array}{c}846 \\
0.225\end{array}$ & $\begin{array}{c}432 \\
0.231\end{array}$ & $\begin{array}{c}414 \\
0.229\end{array}$ \\
\hline
\end{tabular}

Source: Authors' computations using TLSS 2001

Note: ${ }^{\star} p<0.10,{ }^{* \star} p<0.05,{ }^{* \star *} p<0.01$; Cluster-Robust standard errors in brackets.

Table 4.10 Robustness check. Effect of conflict on primary school completion in 2007 , controlling for migration

\begin{tabular}{|c|c|c|c|c|c|c|}
\hline & \multicolumn{3}{|c|}{ Sample1977-1992 } & \multicolumn{3}{|c|}{ Sample1968-1984 } \\
\hline & (1) & $(2)$ & (3) & (4) & (5) & (6) \\
\hline & All & Boys & Girls & All & Boys & Girls \\
\hline \multirow[t]{2}{*}{ Exp in prim school } & -0.033 & $-0.166^{\star \star \star}$ & $0.103^{*}$ & 0.023 & -0.009 & 0.064 \\
\hline & $(0.036)$ & $(0.054)$ & $(0.057)$ & $(0.029)$ & $(0.036)$ & $(0.048)$ \\
\hline \multirow[t]{2}{*}{ N Ys Exp in prim school } & & & & -0.015 & -0.018 & -0.014 \\
\hline & & & & $(0.013)$ & $(0.016)$ & $(0.021)$ \\
\hline Year fe & Yes & Yes & Yes & Yes & Yes & Yes \\
\hline District fe & Yes & Yes & Yes & Yes & Yes & Yes \\
\hline District trend & Yes & Yes & Yes & Yes & Yes & Yes \\
\hline Controls & Yes & Yes & Yes & Yes & Yes & Yes \\
\hline $\mathrm{N}$ & 5446 & 2803 & 2643 & 3963 & 2041 & 1922 \\
\hline
\end{tabular}

Source: Authors' computations using TLSS 2007

Note: ${ }^{*} p<0.10,{ }^{* \star} p<0.05,{ }^{* \star *} p<0.01$; Cluster-Robust standard errors in brackets.

\section{Conclusions}

The aim of this paper was to examine the effects of the conflict in Timor Leste on educational outcomes among boys and girls exposed to the violence that took place in 1999 following the withdrawal of Indonesian troops from the territory. We analysed the short-term impact on primary school attendance and grade deficits in 2001, and the longer-term impact on school completion for cohorts of children of primary school age in 1999 observed in 2007. We also analysed the impact of peaks of violence in the 1970s and 1980s on schooling outcomes in 2007 (among those that were of primary school age at the time of the various violent events), as well as the overall impact of the conflict. This has enabled us for the first time to compare the impact of violent conflict on educational outcomes in the short, medium and long terms.

The conflict in Timor Leste has led to considerable adverse impacts on educational outcomes among children exposed to the violence, boys in particular. We find that the impact of the conflict on girls' education is statistically insignificant in most cases, and positive in some cases. Because girls' educational outcomes were catching-up to boys' education before 1999, we interpret this result as suggesting that the catching up process continued once the 1999 conflict was over. The 25 years of violent conflict had, in contrast, a clear negative impact on the education of boys in Timor Leste. This result is consistent for different peaks of violence throughout the conflict in Timor Leste: the education of boys was more 
negatively affected by peaks of violence in the earlier stages of the conflict, by the violent events in 1999 and on average throughout the overall conflict. Generations of young Timorese boys have therefore experienced considerable reductions in their accumulation of human capital, which may well now be reflected in increases in insecurity, unemployment and violence in the territory since 2006.

We believe this impact of violence on boys' education reflects a potential household investment trade-off between education and economic survival, where boys would have been removed from school (or reduced school attendance) in order to participate in household economic activities. It is also possible that boys (older boys in particular) may have joined the armed rebellion, but we cannot test this hypothesis with the data we have available.

These results have important policy implications. The first is that the reconstruction of the education sector in the immediate aftermath of conflict can produce considerable results in mitigating the destruction caused by the violence. The evidence we have examined seems to suggest that conflict did not impose any significant damage to the catching-up process in girls' education or to education outcomes among some boys. Given the almost total destruction of schools and the lack of teachers and infrastructure, this result may well attest for the success of the reconstruction efforts of the international community and the people of Timor Leste.

The second implication is that reconstruction policies must pay greater attention to their redistributive impacts across gender and across different population characteristics. Although girls recovered quickly from the conflict, boys did not. The mechanisms that explain the adverse consequences of violent conflict on educational outcomes are very complex and differ substantially between boys and girls and across age groups. Policy interventions in post-conflict countries have stressed the disproportional victimization of girls (DFID 2009; UNESCO 2011). However, boys can get caught by adverse impacts of violence in ways that still remain under-researched. The evidence for Timor Leste suggests that boys were very vulnerable to the educational effects of violence. This result implies that much more attention must be paid to understanding how children are affected by violent conflict and the different roles girls and boys assume during and after the conflict.

The third implication is that conflict is not a uniform phenomenon. Violent conflict affects different people and different aspects of their welfare through different channels. In the case of Timor Leste, and in line to evidence from other conflicts such as Colombia (see Ibáñez and Moya 2009, for instance), displacement has particularly adverse effects on educational outcomes. The recently released Education for All Global Monitoring report by UNESCO (2011) portrays displaced populations as the hidden victims of conflict. A significantly disproportional number of displaced children are out of school (even in comparison to conflict-affected populations in the same country), while enrolment rates among displaced populations across the world average around 69 per cent for primary school and 30 per cent for secondary school. The analysis of Timor Leste confirms the extreme disadvantage that displaced populations face in terms of lost educational opportunities. This is likely to affect generations of boys in Timor Leste, possibly perpetuating the risks associated with renewed conflict in the future. 


\section{References}

Akbulut-Yuksel, M. (2009) Children of War: The Long-Run Effects of Large-Scale Physical Destruction and Warfare on Children, HiCN Working Paper 62, Households in Conflict Network, www.hicn.org

Akresh, R. and de Walque, D. (2008) Armed Conflict and Schooling: Evidence from the 1994 Rwandan Genocide, HiCN Working Paper 47, Households in Conflict Network, www.hicn.org

Akresh R. and Verwimp, P. (2006) Civil War, Crop Failure, and the Health Status of Young Children, HiCN Working Papers 19, Households in Conflict Network, www.hicn.org

Akresh, R.; Verwimp, P. and Bundervoet, T. (2011) 'Civil War, Crop Failure, and Child Stunting in Rwanda', Economic Development and Cultural Change 59.4

Alderman, H.; Hoddinott, J. and Kinsey, B. (2006) 'Long Term Consequences of Early Childhood Malnutrition', Oxford Economic Papers 58.3: 450-74

Alonso, A. and Brugha, R. (2006) 'Rehabilitating the Health System after Conflict in East Timor: A Shift from NGO to Government Leadership', Health Policy and Planning 21.3: 206-16

Angrist, J.D. and Kugler, A.D. (2008) 'Rural Windfall or a New Resource Curse? Coca, Income, and Civil Conflict in Colombia', The Review of Economics and Statistics 90.2: 191-215

Annan, J.; Blattman, C.; Mazurana, D. and Carlson, K. (2009) Women and Girls at War: 'Wives', Mothers, and Fighters in the Lord's Resistance Army, HiCN Working Paper 63, Households in Conflict Network, www.hicn.org

Becker, G.S. (1962) 'Investment in Human Capital: A Theoretical Analysis', Journal of Political Economy 70

Bellows, J. and Miguel, E. (2006) 'War and Institutions: New Evidence from Sierra Leone', American Economic Review 96.2: 394-99

Blattman, C. (2009) 'From Violence to Voting: War and Political Participation in Uganda', American Political Science Review 103.2

Blattman, C. and Miguel, E. (2010) 'Civil War', Journal of Economic Literature 48.1: 3-57

Brakman, S.; Garretsen, H. and Schramm, M. (2004) 'The Strategic Bombing of German Cities During World War II and Its Impact on City Growth', Journal of Economic Geography 4.2: 201-18

Brück, T. and Schindler, K. (2009) 'The Impact of Violent Conflicts on Households: What Do We Know and What Should We Know About War Widows?', Oxford Development Studies 37.3: 289-309

Brück, T.; Justino, P.; Verwimp, P. and Avdeenko, A. (2010) Identifying Conflict and Violence in Micro-Level Surveys, HiCN Working Papers 79, Households in Conflict Network, www.hicn.org 
Bundervoet, T.; Verwimp, P. and Akresh, R. (2009) 'Health and Civil War in Rural Burundi', Journal of Human Resources 44.2: 536-63

Case, A. and Paxson, C. (2008) 'Stature and Status: Height, Ability, and Labor Market Outcomes', Journal of Political Economy 116.3

CAVR (2006) Human Rights Violations Database, Commission for Reception, Truth and Reconciliation and Benetech Human Rights Data Analysis Group, 9 February, www.hrdag.org/resources/timor-leste data.shtml

- (2005) Chega! The Report of the Commission for Reception, Truth and Reconciliation in Timor-Leste, Commission for Reception, Truth and Reconciliation in Timor-Leste, www.cavr-timorleste.org/en/chegaReport.htm

Chamarbagwala, R. and Morán, H.E. (2010) 'The Human Capital Consequences of Civil War: Evidence from Guatemala', Journal of Development Economics 94.1: 41-61

Chen, S.; Loayza, N.V. and Reynal-Querol, M. (2007) The Aftermath of Civil War, World Bank Policy Research Working Paper 4190

Dasgupta, P. (1993) An Inquiry into Well-Being and Destitution, Oxford: Clarendon Press

Davis, D.R. and Weinstein, D.E. (2002) 'Bones, Bombs, and Break Points: The Geography of Economic Activity', The American Economic Review 92.5: 1269-89

DFID (2009) Eliminating World Poverty: Building Our Common Future, London: UK Department for International Development

De Walque, D. (2004) The Long-Term Legacy of the Khmer Rouge Period in Cambodia, World Bank Policy Research Working Paper 3446

Duryea, S.; Lam, D. and Levinson, D. (2007) 'Effects of Economic Shocks on Children's Employment and Schooling in Brazil', Journal of Development Economics 84: 118-214

Geneva Declaration Secretariat (2008) Global Burden of Armed Conflict, Geneva Declaration, Geneva

Guerrero-Serdán, G. (2009) The Effects of the War in Iraq on Nutrition and Health: An Analysis Using Anthropometric Outcomes of Children, HiCN Working Paper 55, Households in Conflict Network, www.hicn.org

Harbom, L. and Wallensteen, P. (2009) 'Armed Conflicts, 1946-2008', Journal of Peace Research 46.4: 577-87

Hill, H. (2001) 'Tiny, Poor and War-Torn: Development Policy Challenges for East Timor', World Development 29.7: 1137-56

Ibáñez, A.M. and Moya, A. (2009) Do Conflicts Create Poverty Traps? Asset Losses and Recovery for Displaced Households in Colombia, MICROCON Research Working Paper 10, Brighton: IDS, www.microconflict.eu

Ichino, A. and Winter-Ebmer, R. (2004) 'The Long-Run Educational Cost of World War II', Journal of Labor Economics 22.1: 57-86 
Justino, P. (2010a) War and Poverty, HiCN Working Paper 81, Households in Conflict Network, www.hicn.org

(2010b) 'How Does Violent Conflict Impact on Individual Educational Outcomes? The Evidence So Far', background paper for the Education For All Global Monitoring Report 2011, UNESCO

- (2009) 'Poverty and Violent Conflict: A Micro-Level Perspective on the Causes and Duration of Warfare', Journal of Peace Research 46.3: 315-33

Justino, P. and Shemyakina, O.N. (2008) Remittances and Labor Supply in Post-Conflict Tajikistan, MICROCON Working Paper 35, Brighton: IDS, www.microconflict.eu

Justino, P. and Verwimp, P. (2006) Poverty Dynamics, Violent Conflict and Convergence in Rwanda, HiCN Working Paper 16, Households in Conflict Network, www.hicn.org

Kalyvas, S.N. (2006) The Logic of Violence in Civil War, Cambridge MA: Cambridge University Press

Kondylis, F. (2010) 'Conflict Displacement and Labor Market Outcomes in Post-War Bosnia and Herzegovina', Journal of Development Economics 93.2: 235-48

Kostner, M. and Clark, S. (2007) Timor-Leste Youth in Crisis: Situational Analysis and Policy Options, Washington DC: The World Bank

Maccini, S.L. and Yang, D. (2009) 'Under the Weather: Health, Schooling, and Economic Consequences of Early-Life Rainfall', American Economic Review 99.3: 1006-26

Merrouche, O. (2006) The Human Capital Cost of Landmine Contamination in Cambodia, HiCN Working Paper 25, Households in Conflict Network, www.hicn.org

Miguel, E. and Roland, G. (2006) The Long Run Impact of Bombing Vietnam, CEPR Working Paper, London: Centre for Economic Policy Research

Mincer, J. (1974) Schooling, Experience and Earnings, National Bureau of Economic Research, New York: Colombia University Press

Muggah, R.; Jutersonke, O.; Murray, R.; Rees, E. and Scambary, J. (2010) Urban Violence in an Urban Village. A Case Study of Dili, Timor-Leste, Geneva Declaration Working Paper, Geneva: Geneva Declaration Secretariat

Nicolai, S. (2004) Learning Independence. Education in Emergency and Transition in TimorLeste since 1999, Paris: UNESCO International Institute for Educational Planning

Nugent, J.B. and Gillaspy, T. (1983) 'Old Age Pensions and Fertility in Rural Areas of Less Developed Countries: Some Evidence from Mexico', Economic Development and Cultural Change 31.4: 809-29

O'Malley, B. (2010) Education Under Attack, report commissioned by Division for the Coordination of United Nations Priorities in Education, Education Sector, UNESCO

-(2007) Education Under Attack: A Global Study on Targeted Political and Military Violence Against Education Staff, Students, Teachers, Union and Government Officials, and Institutions, report commissioned by UNESCO, Education Sector, Division for the Co-ordination of United Nations Priorities, 27 April 2007 
Petersen, R. (2001) Resistance and Rebellion: Lessons from Eastern Europe, Cambridge MA: Cambridge University Press

Richter, K. (2009) 'Changes in Subjective Well-being in Timor-Leste on the Path to Independence', World Development 37.29: 371-84

Robinson, G. (2003) East Timor 1999. Crimes Against Humanity, report commissioned by the United Nations Office of the High Commissioner of Human Rights, OHCHR

Rodriguez, C. and Sanchez, F. (2009) Armed Conflict Exposure, Human Capital Investments and Child Labour: Evidence from Colombia, HiCN Working Paper 68, Households in Conflict Network, www.hicn.org

Rohland, K. and Cliffe, S. (2002) The East Timor Reconstruction Program: Successes, Problems and Tradeoffs, Working Paper 2, The World Bank Conflict Prevention and Reconstruction Unit

Santos, R. (2010) 'In the Wake of Independence - Timorese Youth and Conflict', MPhil thesis, Institute of Development Studies, Brighton

Scambary, J. (2009) 'Anatomy of a Conflict: The 2006-2007 Communal Violence in East Timor', Conflict, Security and Development 9.2: 265-88

Schultz, T.W. (1961) 'Investment in Human Capital', American Economic Review 51.1: 1-17

Shemyakina, O. N. (2011) 'The Effect of Armed Conflict on Accumulation of Schooling: Results from Tajikistan', Journal of Development Economics 95.2: 186-200

_ (2009) The Marriage Market and Tajik Armed Conflict, HiCN Working Paper 66, Households in Conflict Network, www.hicn.org

Silva, R. and Ball, P. (2006) The Profile of Human Rights Violations in Timor-Leste, 19741999, a report by the Benetech Human Rights Data Analysis Group to the Commission on Reception, Truth and Reconciliation, 9 February 2006, available at http://www.hrdag.org/timor

TLSS (2007a) Timor-Leste Household Survey 2007, Direcção Nacional de Estatística, Ministério de Finanças, Timor-Leste

— (2007b) Final Statistical Abstract: Timor-Leste Survey of Living Standards 2007, Direcção Nacional de Estatística, Ministério de Finanças, Timor-Leste

_ (2001) Timor-Leste Household Survey 2001, Direcção Nacional de Estatística, Ministério de Finanças, Timor-Leste

UNDP (2006) East Timor Human Development Report 2006. The Path Out of Poverty. Integrated Rural Development, New York: UNDP

_ (2002) East Timor Human Development Report 2002. The Way Ahead, New York: UNDP

UNESCO (2011) The Hidden Crisis: Armed Conflict and Education, Education for All Global Monitoring Report, UNESCO

UNHCR (2008) UNHCR Global Report, New York: United Nations Refugee Agency 
Verwimp, P. and Bundervoet, T. (2008) Consumption Growth, Household Splits and Civil War, ECARES Working Paper 23, Brussels: European Centre for Advanced Research in Economics and Statistics

Verwimp, P. and Van Bavel, J. (2005) 'Child Survival and Fertility of Refugees in Rwanda', European Journal of Population 21: 271-90

Voors, M.; Nillesen, E.; Verwimp, P.; Bulte, E.; Lensink, R. and van Soest, D. (2010) Does Conflict Affect Preferences? Results from Field Experiments in Burundi, MICROCON Working Paper 21, Brighton: IDS, www.microconflict.eu

Wood, E.J. (2003) Insurgent Collective Action and Civil War in El Salvador, Cambridge: Cambridge University Press

World Bank (2010) World Development Indicators, Washington DC: The World Bank, available at http://data.worldbank.org/indicator (accessed 1 May 2010)

— (2003a) Timor Leste Education. The Way Forward, Washington DC: The World Bank

(2003b) Timor Leste. Poverty in a New Nation: Analysis for Action, Washington DC: The World Bank 